\title{
The Demand for Military Spending in Sub-Saharan Africa
}

by

\author{
Decky Kipuka Kabongi
}

A thesis submitted to the Faculty of Graduate and Postdoctoral Affairs

in partial fulfillment of the requirements for the degree of

Doctor of Philosophy

in

International Affairs

Carleton University

Ottawa, Ontario

(C) 2018

Decky Kipuka Kabongi 


\begin{abstract}
This dissertation examines the demand for military spending in Sub-Saharan Africa. It comprises three chapters. The first chapter uses a qualitative method, including key informant interviews, to examine four important issues related to Uganda's defence budget: the process leading to its formulation, the key actors involved in that process, the structure of military expenditures, and the internal and external threat environment. The analysis in that chapter shows that defence spending in Uganda generally follows a process of intra-governmental bargaining and political oversight over public expenditures. Despite the government's military roots, and the President's ultimate control over military spending, the defence budget has not overwhelmed other government priorities. In addition, the nature and level of internal and external threats to Uganda do not seem to pose a serious challenge to its security. While there are several perceived threats that may influence Uganda's defence budget, the limited volatility of military spending over time suggests that overall there is a perception that Uganda's government has been able to provide a reasonable level of security without compromising its obligations to promote social and economic development as well.

Chapter two examines empirically the factors associated with the level and changes in military budget in Uganda, using an auto-regressive distributed lag model. This quantitative methodology complements the qualitative approach used in chapter one by testing whether factors identified in the interviews are also found to be important statistically. The analysis shows that there is a long-run relationship between Uganda's military expenditure and real GDP, net official development assistance and security dynamics at regional level. Detailed analysis about which neighbour's military spending affects Uganda, however, is often different from expectations based on the interviews.
\end{abstract}


Chapter three uses panel data to examine military spending in a sample of 30 of SubSahara African countries for the period of 1988-2016, the largest sample for which data are available. Two distinct specifications are performed, a fixed effects model and a dynamic panel data model. The results of different regressions performed in this chapter show that the size of the economy, demography, changes in the level of military spending of neighbouring countries, and the lagged of military spending are the most important explanatory variables of the demand for military spending in Sub-Saharan Africa. Furthermore, the estimations of the fixed effect models show that the nature of the political regime (autocracy and democracy) and the occurrence of civil war also influence the defence budget. However, the estimations of the dynamic panel models fail to corroborate this influence. Finally, post-estimation tests show that both the fixed effect and dynamic panel data models are suitable and efficient for this analysis. 


\section{Acknowledgments}

The completion of this dissertation could not have come to fruition solely because of my own efforts. Throughout the process of this $\mathrm{PhD}$ thesis, I benefited enormously from the support, contribution and encouragement of numerous individuals. I would therefore like to express my sincere gratitude to all of them.

Primarily, my sincere appreciations go to my thesis supervisor, Dr. Dane Rowlands, for his research guidance, unfailing patience, and tremendous support he provided since the first day I approached him to supervise my research. Without his support, I would not be submitting this dissertation to Carleton University.

Second, I am heavily indebted to my wife Gina, my son Emmanuel, and my daughters Dorothy and Samantha for their patience and sacrifice. On several occasions, I was not able to discharge my parental responsibilities as they expected me to do because I had to devote all my attention, most of my time and efforts to the completion of this project. Repeatedly, I was away from the family home, working longer hours and late nights in libraries, or traveling to Uganda for research purposes. It is because of their love and patience that I was able to complete this dissertation.

I am also indebted to Dr. Charlotte Karungi Mafumbo at Makerere University for her support prior to and during the fieldwork I conducted in Kampala in the summer of 2016 and in the winter of 2018. It is with all her dedication that she accepted to supervise my fieldwork on such a sensitive topic as Uganda's military budget. Without Charlotte's willingness to support my research, I would not have received the research permit from the Ugandan National Council for Science and Technology (UNCST). She defended my application for the research permit at the Office of the President of Uganda where some officials thought that I was undertaking an 
espionage mission on Uganda's defence posture. While in Kampala, she provided me with the proper guidance and advice regarding the interview process with the research participants. She introduced me to the Uganda People's Defence Forces (UPDF) and facilitated my contacts with other senior Ugandan public servants and academics at the Ugandan Parliament and Makerere University. She also facilitated my contacts with many of her graduate students in the army. I owe Charlotte a lot for all her support for my research.

My fieldwork to Uganda could not have been as success as it was without the collaboration of all the research participants that I wish I could name here. I have to say thank you to the many journalists, professors at Makerere University, public servants at the Uganda Parliament and the Ministry of Finance, and all the Generals of the UPDF for accepting to answer my interview questions. You all educated me with your insights and deep knowledge of Uganda's internal and external security dynamics. Without your collaboration, I could not have all the information I needed for the first chapter of this dissertation. To all of you I say "Kale" (i.e thank you in Luganda).

Thanks so much as well to my colleagues, administrative staff, and Faculty members I interacted with in the Norman Paterson School of International Affairs (NPSIA) for the discussions and encouragement. It was such a pleasure to meet, go for lunch at the University's food centre and talk to each of you and to discover your passion for life and academic interests.

I would also like to express my gratitude to Carleton University's Office of Graduate Studies and to the Canadian Network for Research on Terrorism, Security and Society (TSAS) for the research awards I received. Without your generous financial support, I would not have been able to travel to Kampala. 
Finally, special thanks to my siblings in the Democratic Republic of the Congo whom I have not seen for decades for their endurance. Being far away from you for so many years has been a painful life experience for all of us, essentially after the passing away of our loving parents. The desire to achieve my academic ambition took me too far to the point of forgetting to provide you with the necessary support as your unique oldest brother. Everyday I think of you, I hear the silent voice of our parents, reminding me not to forget you. I hope I will be able, one day, to share with you the benefits of my education. 


\section{List of Figures}

Figure \# 1. Military Spending in Sub-Saharan Africa (billion, constant 2015 US\$)

Figure \# 2. Countries with Higher Average Military Burden (1988-2016)

Figure \# 3. Countries with Lower Average Military Burden (1988-2016)

Figure \# 4. Average Military Burden at Sub-Regional levels (1988-2016)

Figure \# 5. Military Burden of Countries in the Horn of Africa (1988 - 2016)

Figure \# 6. Average Military Burden in the African Great Lakes Region (1988-2016)

Figure \# 7. Average Military Burden in West Africa (1988-2016)

Figure \# 8. Average Military Burden in Southern Africa (1988-2016)

Figure \# 9. Military expenditure in Angola (1988 -2016)

Figure \# 10. Military Expenditure in Ghana (1988-2016)

Figure \# 11. Military Expenditure in Nigeria (1988-2016)

Figure \# 12. Military Expenditure in Ethiopia (1988-2016)

Figure \# 13. Military Expenditure in Rwanda (1988-2016)

Figure \# 14. Military Expenditure in South Africa (1988-2016)

Figure \# 15. Distribution of Research Participants by Profession

Figure \# 16. Trend of Defence Allocations vis-a-vis Development Spending

Figure \# 17. Proportions of Sectoral Allocations in the National Budget

Figure \# 18. The Structure of Uganda's Ministry of Defence

Figure \# 19. Linkage between the Army’s Vision and Mission

Figure \# 20. Population Density in the African Great Lakes Region

Figure \# 21. Trend of Uganda’s Military Expenditure, 1973-2016 (in million, constant 2015 US\$) 


\section{List of Tables}

Table 1. Determinants of Military Expenditures: An Overview of the Literature

Table 2. Structure of Defence Budget Allocations (Billions, Uganda Shillings)

Table 3. Proportion of Classified Expenditures in Other Recurrent Expenditures

Table 4. Proportion of Classified Expenditures in the Defence Budget

Table 5. Uganda's Trade with its neighbours (US\$ millions, 2000-2016)

Table 6. Variables' Description and Sources of Data

Table 7. Descriptive Statistics of Variables

Table 8. Results of the Augmented Dickey Fuller Test for Unit Root

Table 9. Summary of the Johansen Test of Co-integration

Table 10. Estimation Results

Table 11. Empirical Results for Models using Individual Country |Defence Spending

Table 12. Descriptive Statistics

Table 13. Empirical Results of Fixed Effect Estimations

Table 14. Results of the Fisher Test of Stationarity for the Panel Data

Table 15. Empirical Results of the Dynamic Panel Data Estimations 


\section{Table of Contents}

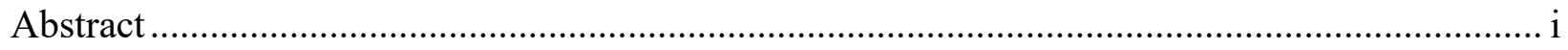

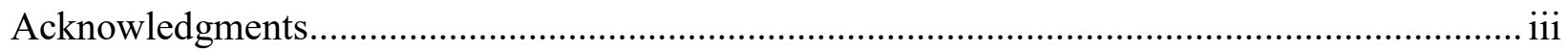

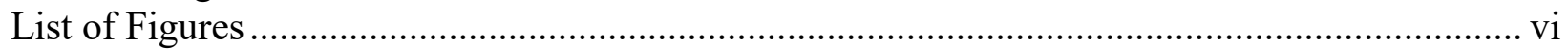

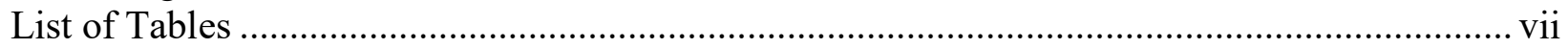

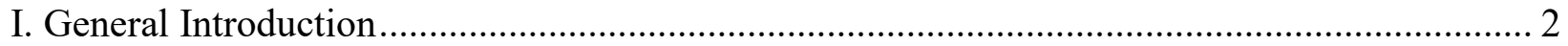

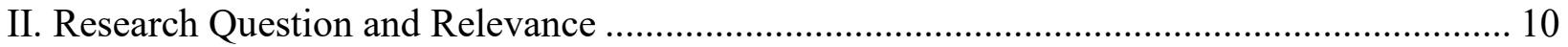

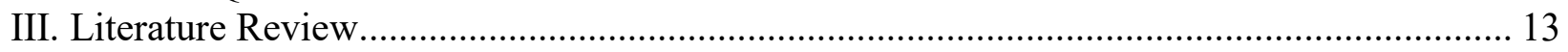

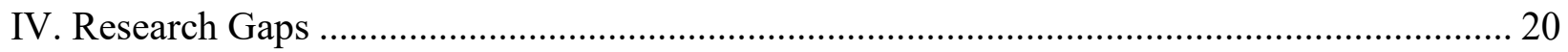

V. Theoretical Framework and Assumptions ………........................................................... 22

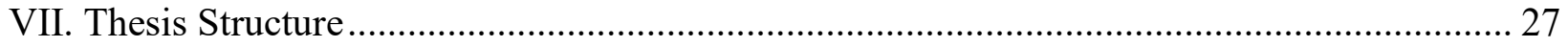

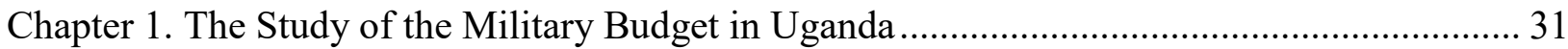

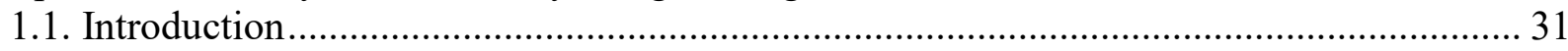

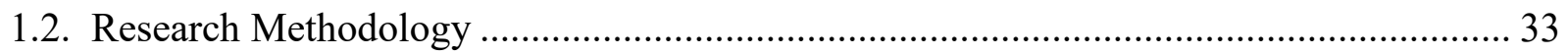

1.3. The Process and Structure of Military Budget in Uganda. ................................................ 37

1.3.1 The Process of Generating Uganda's Defence Budget ....................................................

1.3.2 On Classified Defence Expenditures..................................................................................4

1.3.3 Structure of Uganda's Defence Budget ..........................................................................4

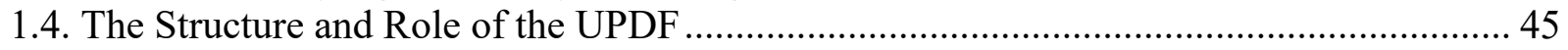

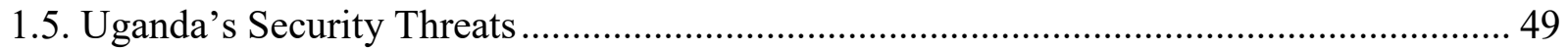

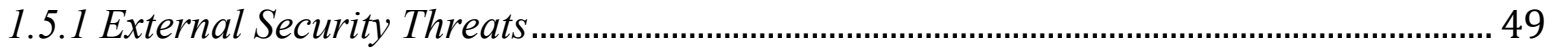

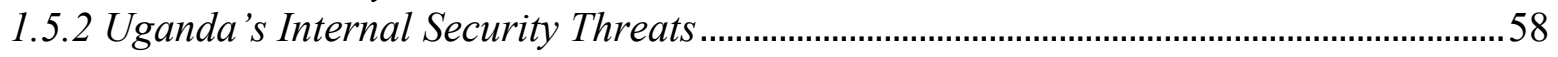

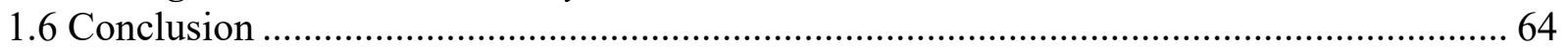

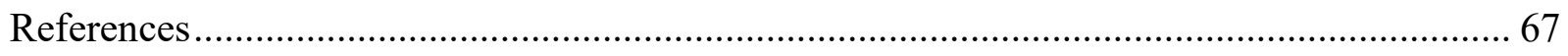

Chapter 2. The Demand for Defence Spending in Uganda: A Time-Series Analysis .................. 70

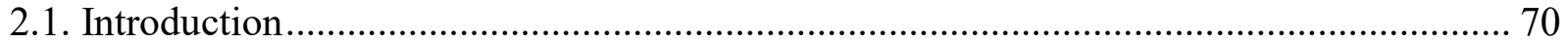

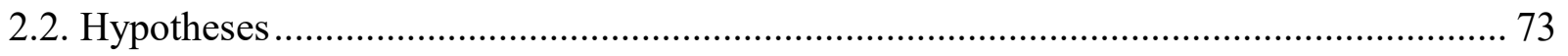

2.3. Variable Descriptions and Data Sources....................................................................... 77

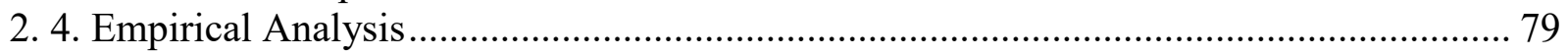

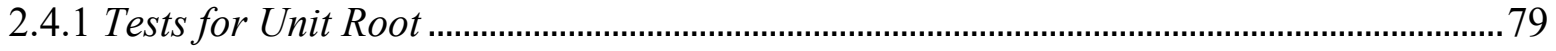

2.4.2 Test of Co-Integration ………………………………...................................................... 80

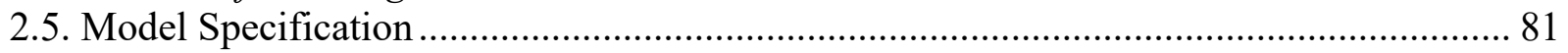

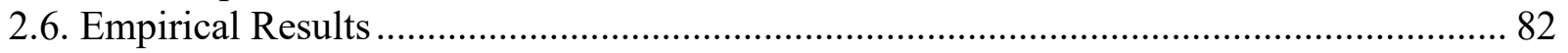

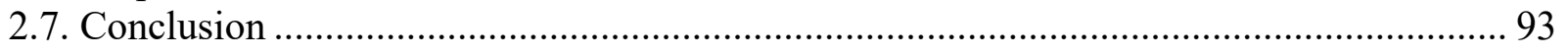

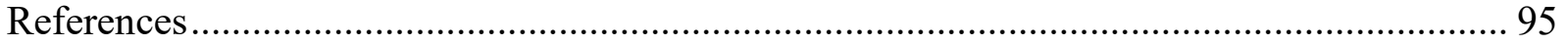

Chapter 3. The Demand for Military Spending in Sub-Saharan Africa: A Panel Analysis........... 96

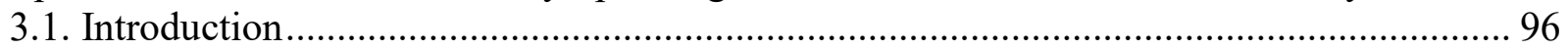

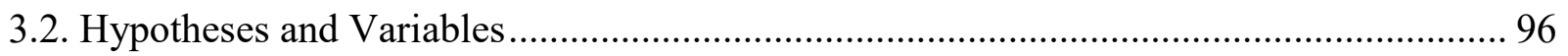

3.3. Model Specification ..................................................................................................... 101

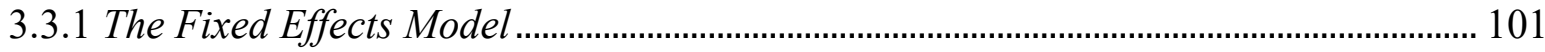

3.3.2 The Dynamic Panel Data Model ................................................................................. 105

3.4. Post Estimation and Robustness Tests....................................................................... 109

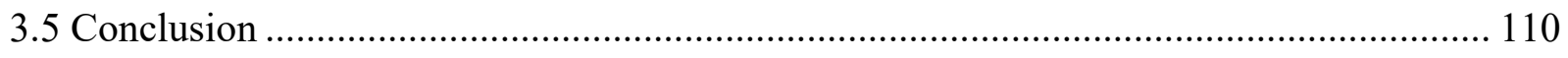

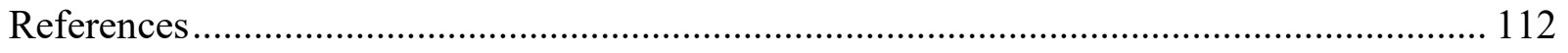

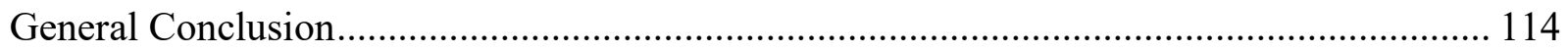




\section{General Introduction}

Military expenditures ${ }^{1}$ (in constant 2015 US dollars) have been generally increasing in Sub-Saharan Africa (SSA) since the mid-1990s, despite numerous development challenges facing governments and populations in the region. Statistics from the Stockholm International Peace Research Institute (hereafter SIPRI) show that between 1980 and 2015, defence spending increased by 71 percent, rising from US\$ 12.4 billion in 1980 to US\$ 21.2 billion in $2015^{2}$. Figure \# 1 exhibits the trend of military spending in the SSA region.

Figure \# 1. Military Spending in Sub-Saharan Africa (billion, constant 2015 US\$)

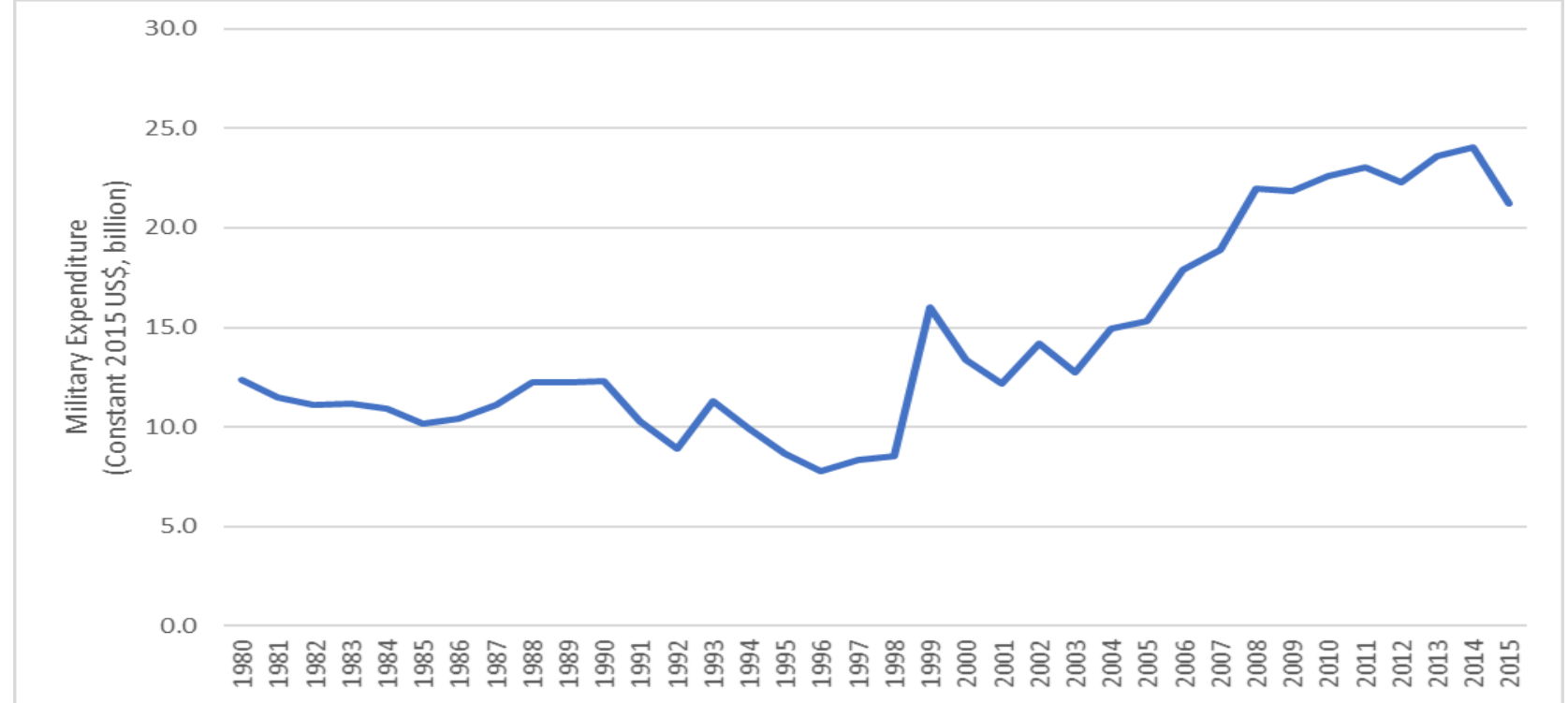

Source: SIPRI Military Expenditures Database

Aside from this observed general pattern, there are substantial variations in both military spending (absolute values) and military burden (defined as share of military expenditures to GDP) across countries, across sub-regions, and over time. For instance, Figure 2 below shows

\footnotetext{
1 Throughout this research, I adopt SIPRI's definition of military expenditures as, where possible, "all current and capital expenditure on: i) the armed forces, including peace keeping forces, ii) defence ministries and other government agencies engaged in defence projects, iii) paramilitary forces when judged to be trained, equipped and available for military operations, military space activities, as well as expenditures on personnel (all expenditures on current personnel, military and civil, retirement pensions of military personnel, social services for personnel and their families), operations and maintenance, procurement, military research and development, military construction, and military aid (in the military expenditures of the donor country). See SIPRI at http://www.sipri.org/research/armaments/milex/milex database/definitions.
}

${ }^{2}$ Dollar figures refer to real constant dollar figures (base year $=2015$ ) unless otherwise specified. 
that 12 of the 29 countries included in the sample had a higher defence burden than the remaining 17 countries (compared to the sub-continent's average military burden of 2.5 percent over the period of 1988-2016), while figure 3 shows countries that spend below the average.

Figure \# 2. Countries with Higher Average Military Burden (1988-2016)

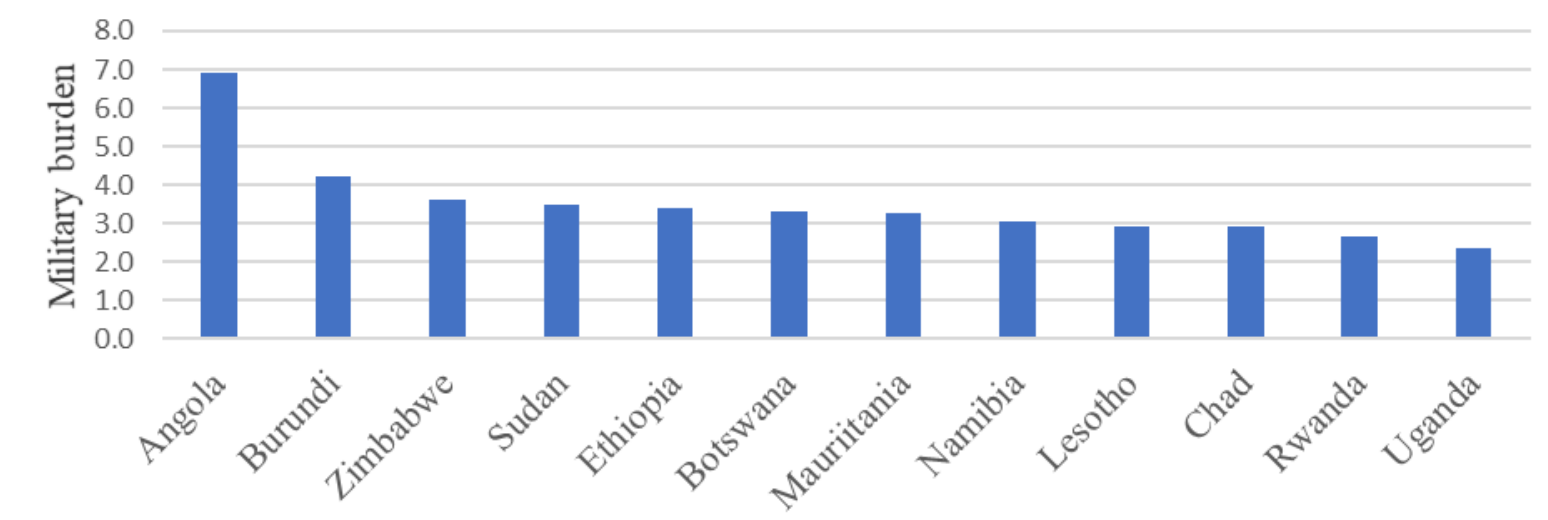

Source: Author's calculations from SIPRI Military Expenditures Database

Figure \# 3. Countries with Lower Average Military Burden (1988-2016)

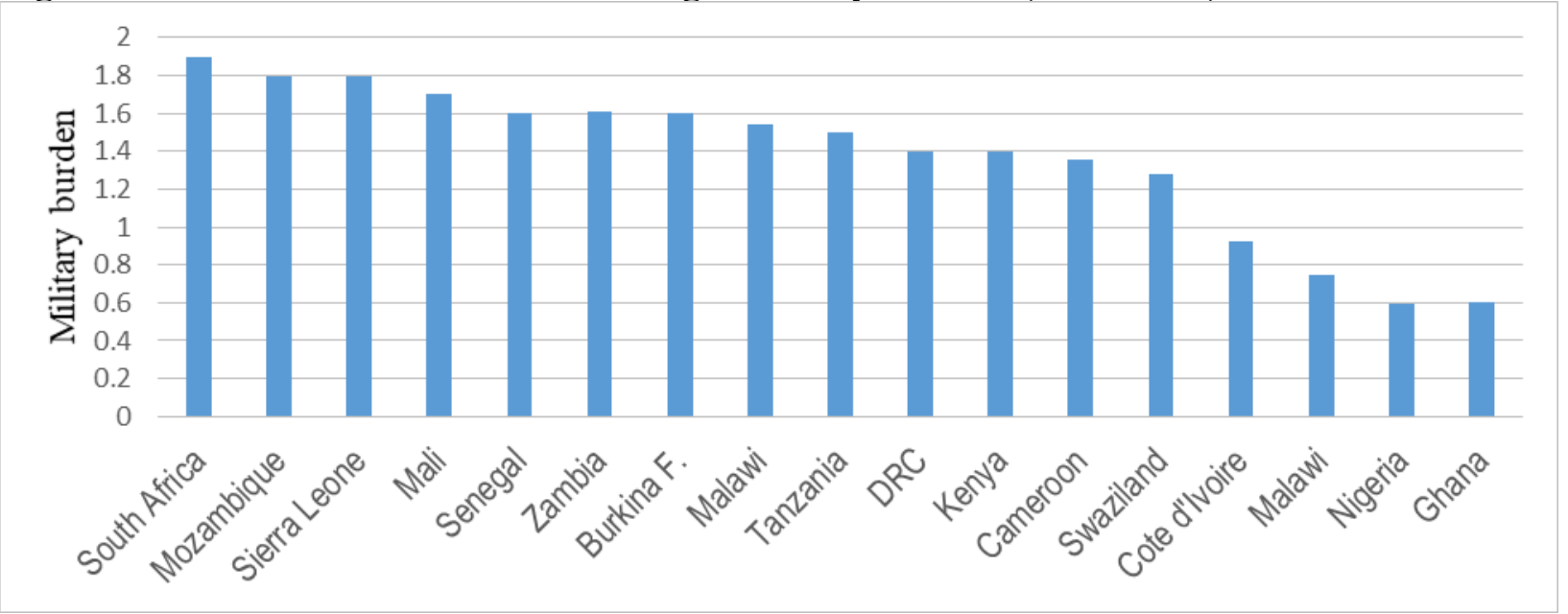

Source: Author's calculations from SIPRI Military Expenditures Database 
Figure \# 4. Average Military Burden at Sub-Regional levels (1988-2016)

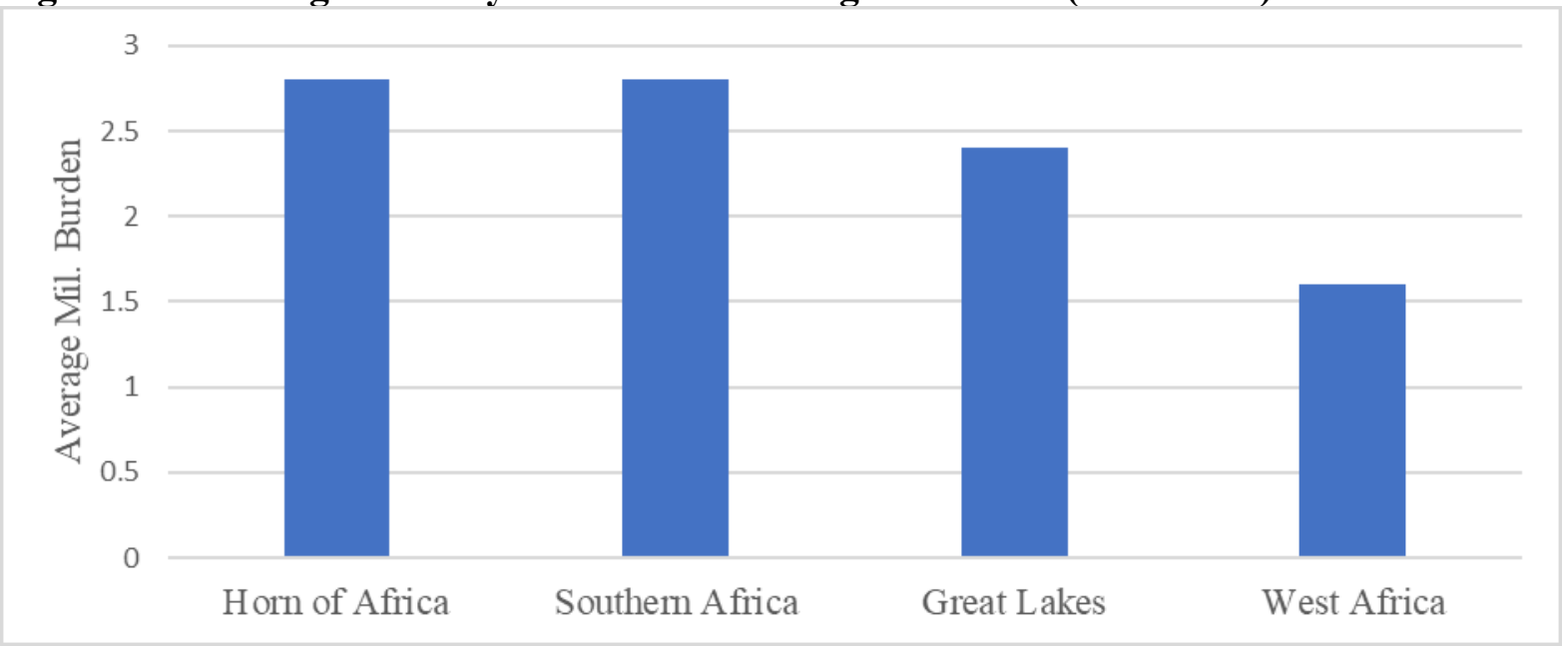

Source: Author's calculation from SIPRI Military Spending database

Figure 4 portrays the military burden at sub-regional levels and shows that the Horn of Africa $^{3}$ and the Southern-Africa ${ }^{4}$ sub-regions have an average military burden higher than other sub-regions. The African Great Lakes sub-region (including Burundi, the DR Congo, Rwanda, Tanzania, and Uganda) comes second with an average military burden of 2.4 percent, while West Africa $^{5}$ has the lowest average defence burden (1.6 percent).

There are also substantial variations within each sub-region that are worth noting. For instance, figure 5 below shows that within the Horn of Africa, Sudan and Ethiopia have the highest military burden (3.5 and 3.4 percent, respeectively). They are followed by Uganda (2.4 percent), while Kenya has the lowest defence burden (1.8 percent). Figure 6 shows that Burundi has the highest average military burden in the Africa Great Lakes sub-region (4.2 percent). Rwanda comes in the second position with an average military burden of 2.7 percent, followed

\footnotetext{
3 The Intern-Governmental Authority for Development (IGAD) defines the Horn of Africa as the region comprising Djibouti, Eritrea, Ethiopia, Kenya, Somalia, South Sudan, Sudan, and Uganda. However, I exclude Djibouti and Somalia in the sample because they lack data on military spending for many years.

${ }^{4}$ Comprising Botswana, Lesotho, Malawi, Mozambique, Namibia, South Africa, Swaziland, Zambia, and Zimbabwe.

${ }^{5}$ Comprising, Burkina Faso, Cameroon, Chad, Cote d'Ivoire, Gambia, Ghana, Mali, Mauritania, Nigeria, Senegal, and Sierra Leone.
} 
by Uganda with an average military burden of 2.4 percent, while the DR Congo and Tanzania have the lowest average military burden (1.5 percent and 1.4 percent, respectively).

Figure \# 5. Military Burden of Countries in the Horn of Africa (1988 - 2016)

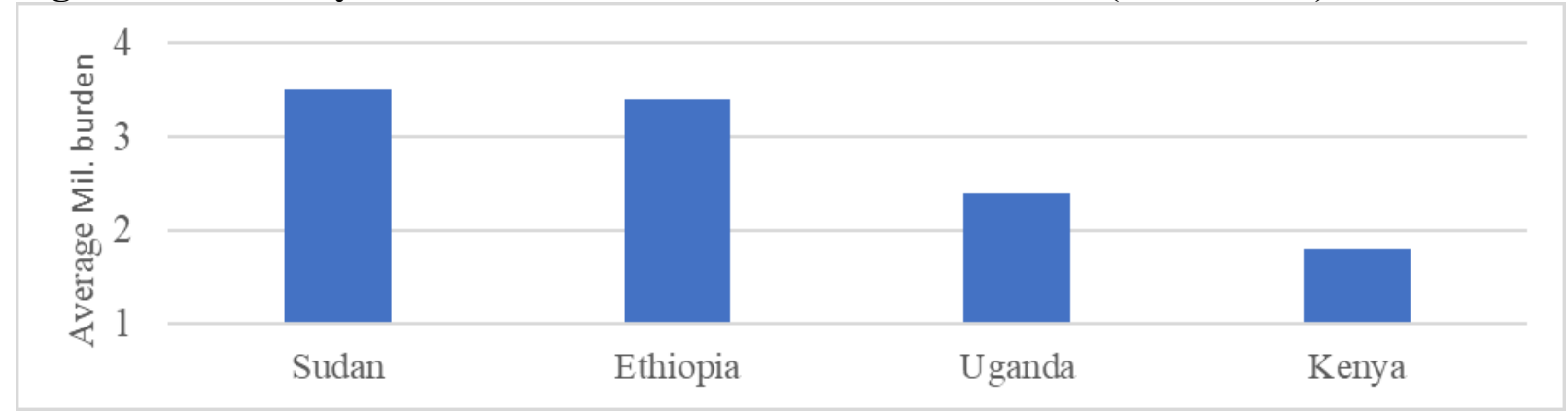

Source: Author's calculation from SIPRI database

Figure \# 6. Average Military Burden in the African Great Lakes Region (1988-2016)

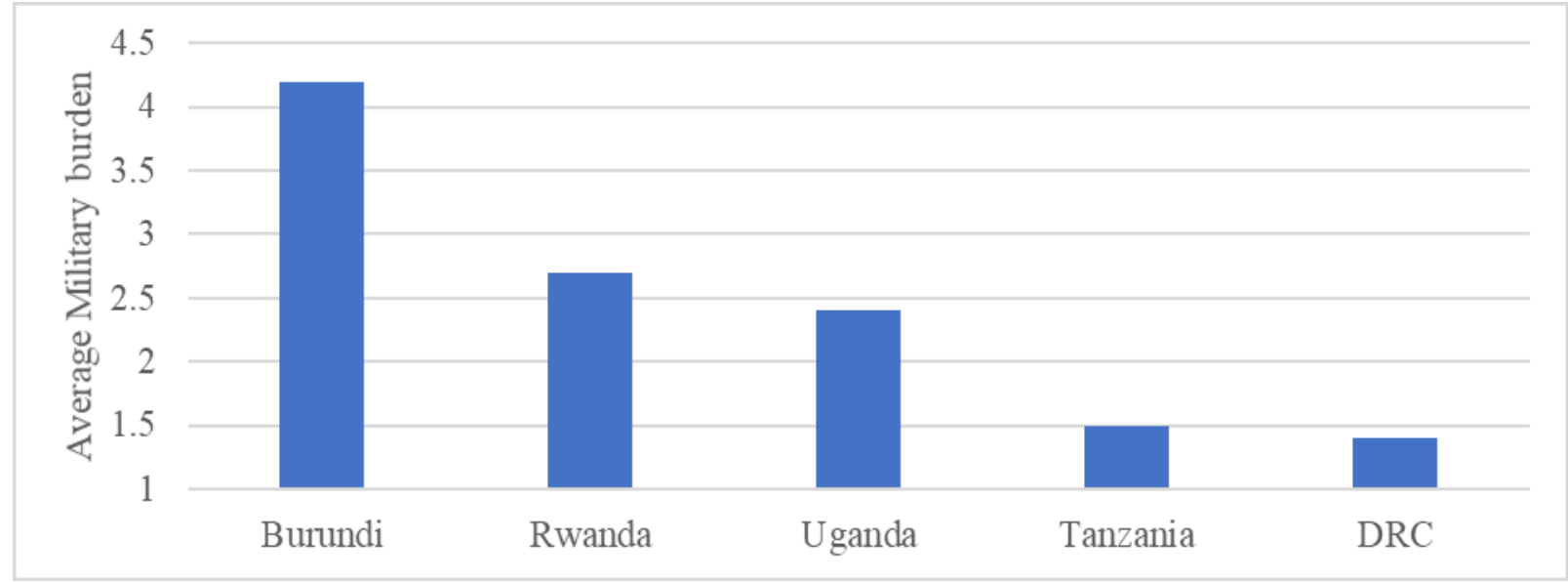

Source: Author's calculation from SIPRI database

Figures 7 and 8 portray variations of military burden within the West Africa and Southern Africa sub-regions, respectively. Figure 7 indicates that Mauritania has the highest average military burden (3.2 percent of GDP), followed by Chad. Surprisingly, Nigeria and Ghana, the more advanced economies in the region have the lowest militay burdens $(0.8$ percent and 0.6 percent, respectively). 
Figure \# 7. Average Military Burden in West Africa (1988-2016)

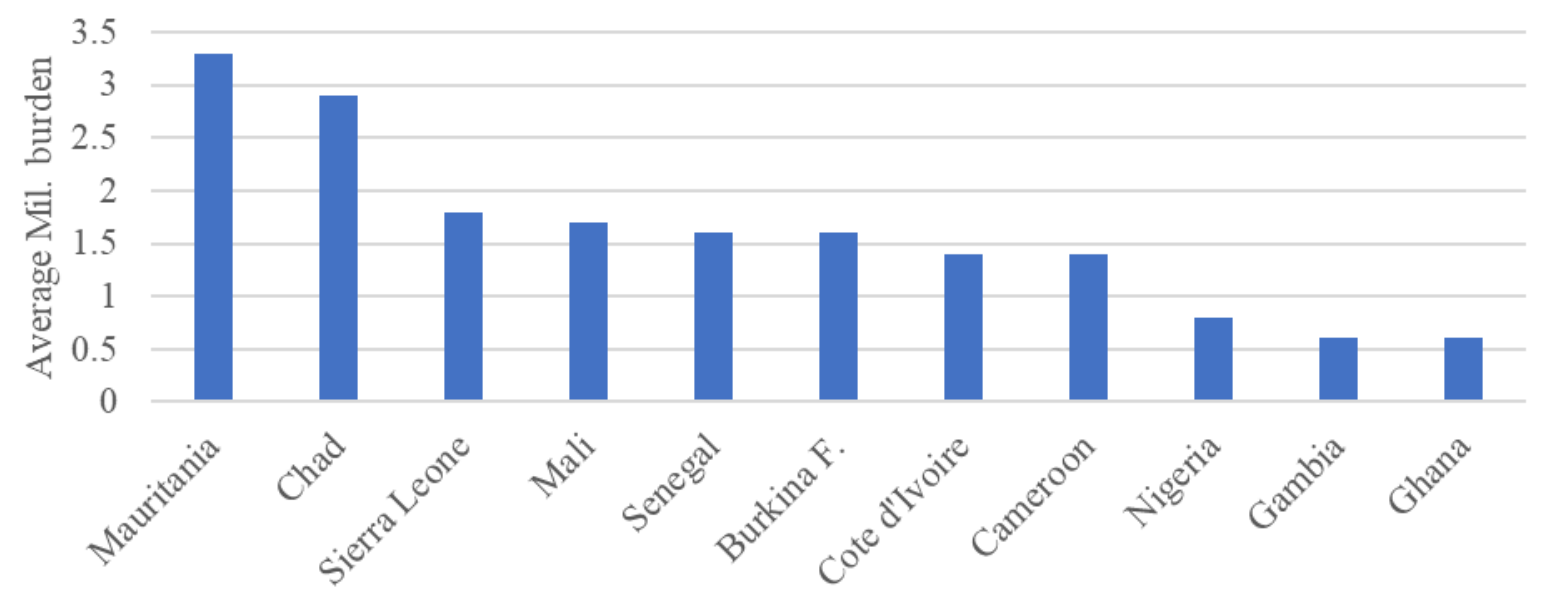

Source: Author's calculation from SIPRI database

Finally, Figure 8 shows that Angola has the highest average military burden in the Southern-Africa sub-region (6.9\%), followed by Zimabwe (3.6 percent); whereas South Africa, one of the richest nations in the region, has an average military burden of nearly 2 percent..

Figure \# 8. Average Military Burden in Southern Africa (1988-2016)

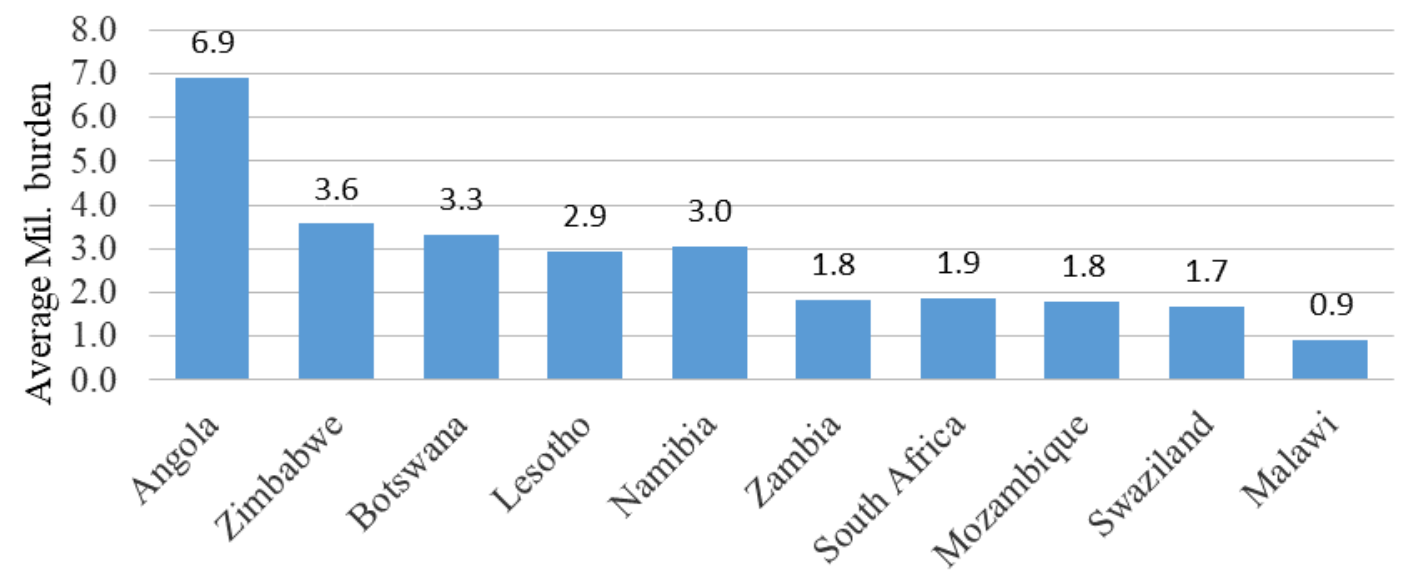

Source: Author's calculation from SIPRI database 
In addition to the observed variations at sub-regional levels, there are also high levels of volatility in the levels of military expenditures ${ }^{6}$ within countries and across time. For instance, Figures 9 to 14 portray such volatility of defence spending in levels and as a proportion of GDP in some selected countries.

Figure \# 9. Military Expenditure in Angola (1988 -2016)

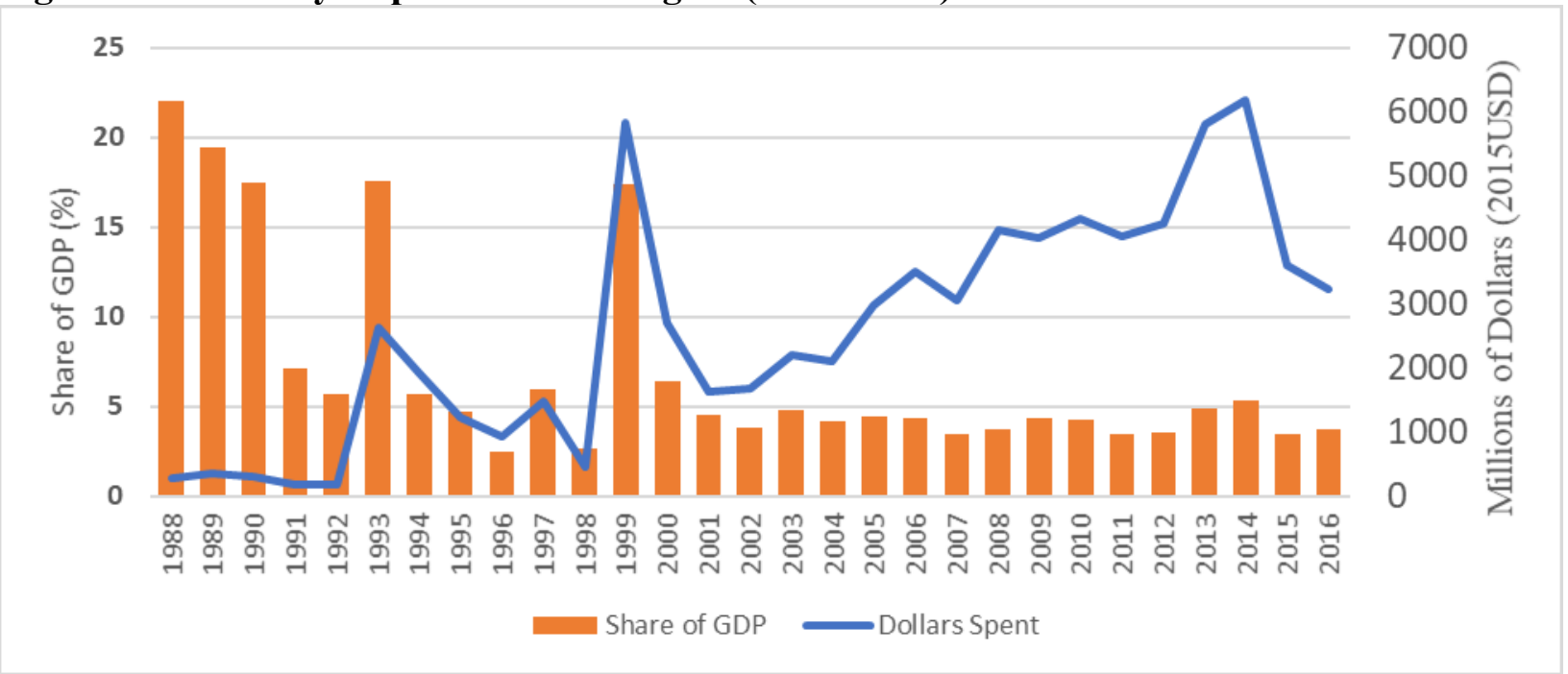

Source: SIPRI Military Expenditures database

Figure \# 10. Military Expenditure in Ghana (1988-2016)

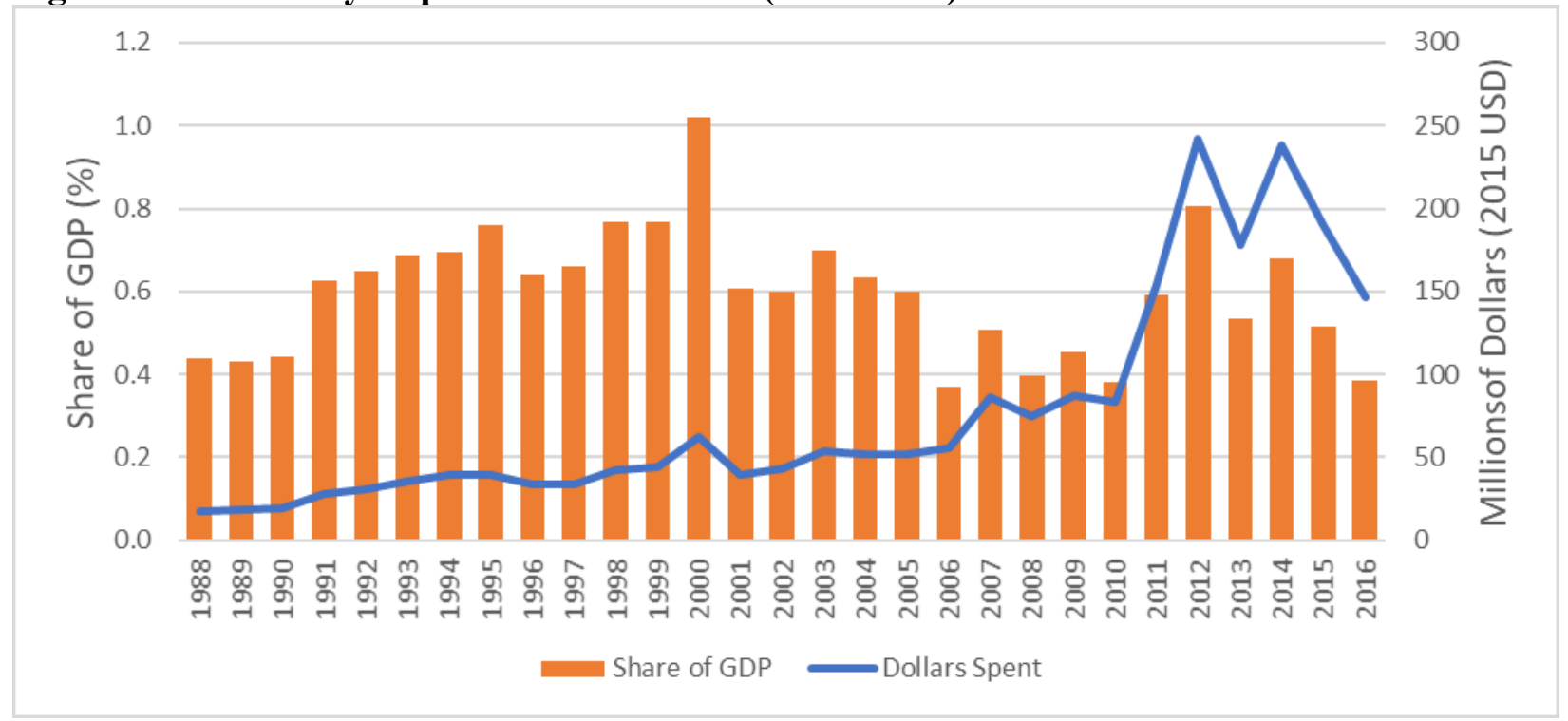

Source: SIPRI Military Expenditures database

\footnotetext{
${ }^{6}$ It is important to note that I use the level of military expenditures at country level because it is the policy variable; while I use military burden (proportion of GDP) for comparing across-countries.
} 
Figure \# 11. Military Expenditure in Nigeria (1988-2016)

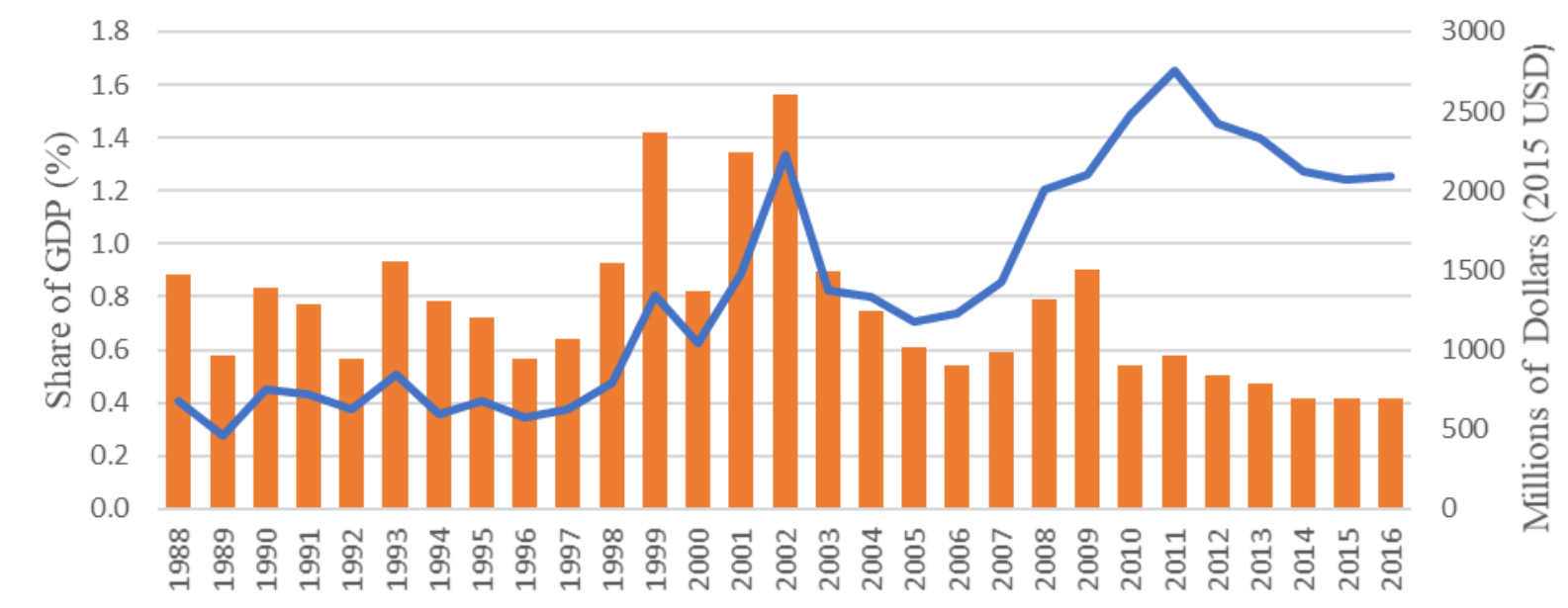

Source: SIPRI Military Expenditures database

Figure \# 12. Military Expenditure in Ethiopia (1988-2016)

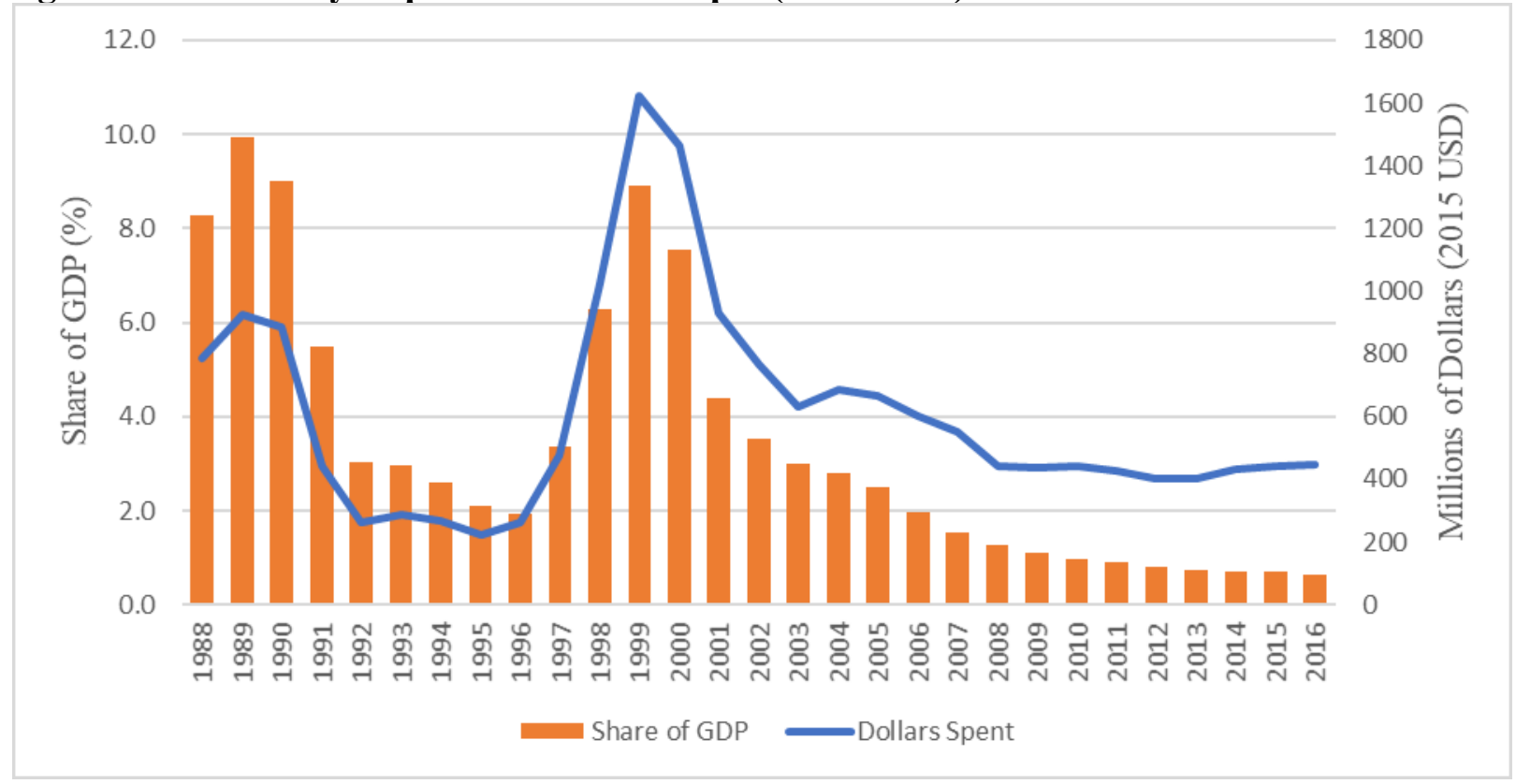

Source: SIPRI Military Expenditures database 
Figure \# 13. Military Expenditure in Rwanda (1988-2016)

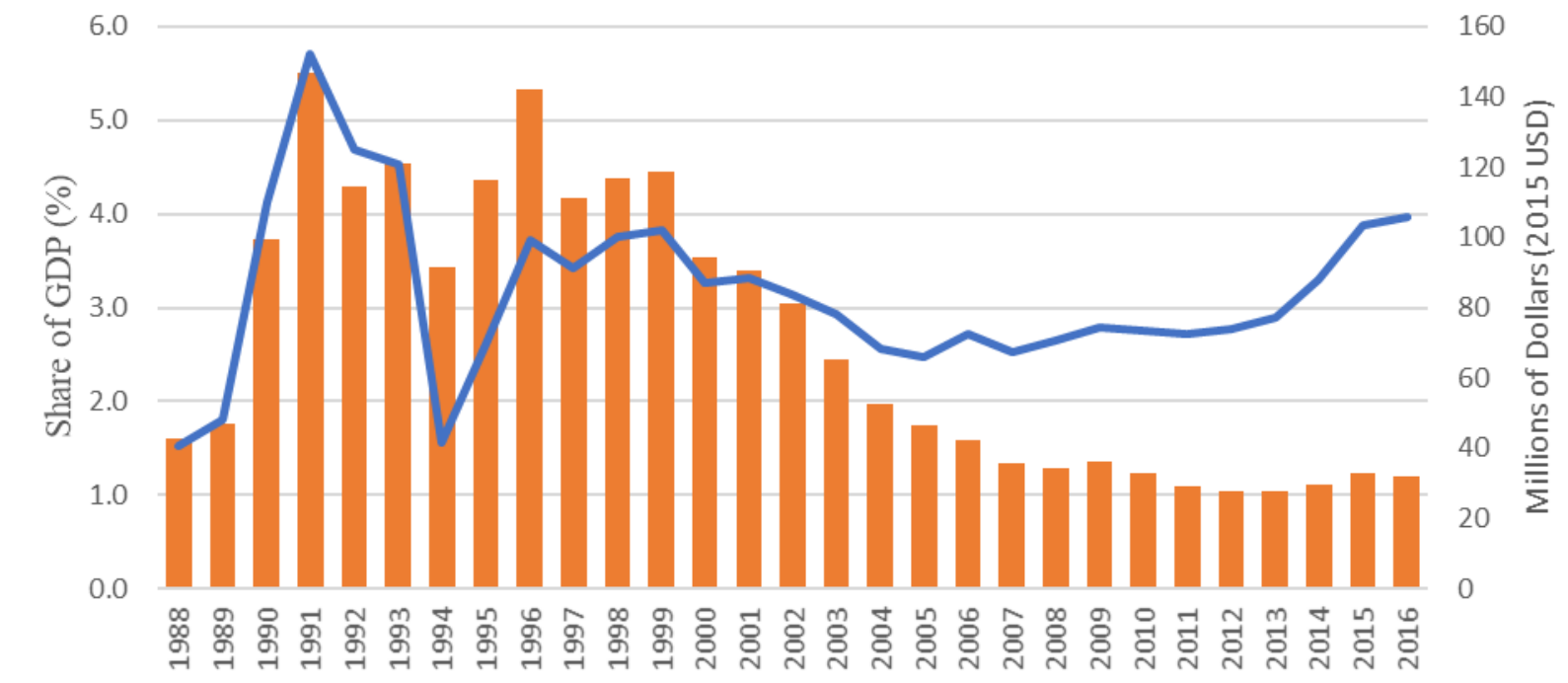

Share of GDP Dollars Spent

Source: SIPRI Military Expenditures database

Figure \# 14. Military Expenditure in South Africa (1988-2016)

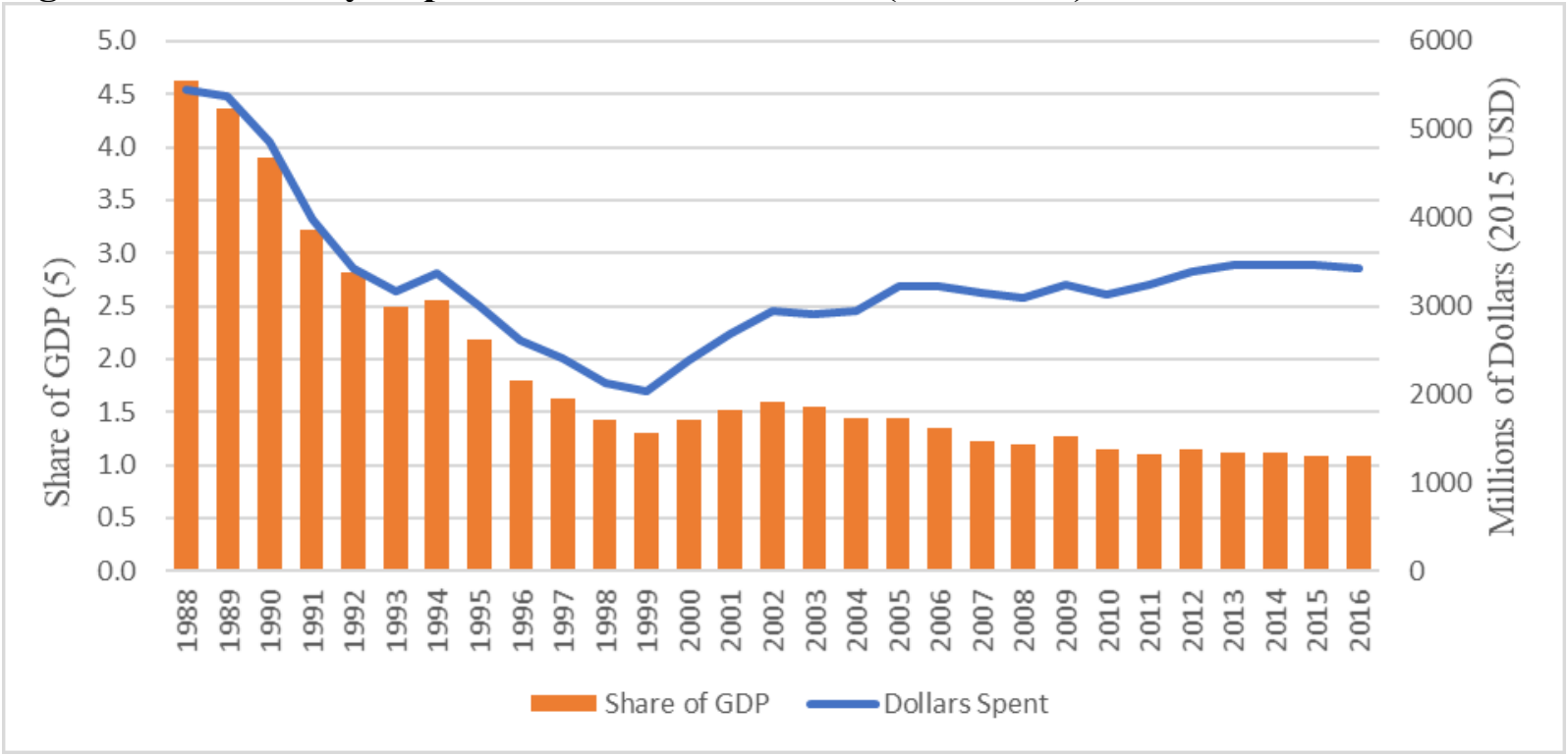

Source: SIPRI Military Expenditures Database 


\section{Research Question and Relevance}

As shown above, military expenditures in Sub-Saharan Africa exhibit important variations: a general trend of growth over time, significant differences between countries and between sub-regions, and distinct patterns of spending over time between and within countries. Hence, the research question that is the focus of this thesis is as follows: Why is there such variation in military expenditures in Sub-Saharan Africa, across time, across countries and sub-regions? Answering this question is the main purpose of this research. Specifically, I seek to empirically identify the key national, sub-regional and regional determinants of military spending in Sub-Saharan Africa. I hope to be able to explain the trend in regional military spending over time, the inter-country and inter-sub-regional levels and patterns of expenditure, and the within country variations over time for key states.

From a public policy perspective, understanding why the levels of military expenditures and their growth in Sub-Saharan Africa are on the rise is important for several reasons. On the one hand, military expenditures are crucial for states because they represent investment in the production of order and security, two public goods that are conducive to development when states sufficiently provided them (Rotberg, 2003 and 2012). Research has shown that in countries where military expenditures are high, states have the ability to effectively control their territories; which is not the case in countries where they are low (Herbst, 2000). From the perspective of international relations, realists argue that a state's military capability is its main instrument for achieving national security. Within the realist paradigm of IR, given the anarchical nature of the international system, every state has the obligation to ensure its own survival against external security threats. Therefore, military spending is crucial in ensuring the state's capability to defend its territory and citizens from foreign aggression. Sub-Saharan Africa provides an 
interesting case for applying this theory, since traditional inter-state conflict is rare, and so our conception of this traditional approach needs to be broadened to incorporate the military's role in the context of external threats from foreign actors, external threats arising from internationalized internal conflicts, and internal threats in the form of civil wars and insurgencies.

On the other hand, military expenditures are generally seen as a resource diversion away from other forms of more productive investment and beneficial consumption, and thus they have a negative impact on development (Smith, 1977; Deger and Smith, 1983; Faini et al., 1984, Chan, 1988; Dommen and Maizels, 1988; Chowdhury, 1991; and Dunne, 1996). This resourcediversion argument maintains that the more countries spend on the military, the more they reduce the amount of resources available for productive sectors of the economy that have the potential for fostering sustainable growth and poverty reduction. The policy dilemma is that developing countries need to strike the balance in the allocation of scarce resources between the military and sectors that foster development.

Based on the above discussion and given the widespread poverty in Sub-Saharan Africa, it is thus important to understand the drivers of increases in military spending in the subcontinent. On the one hand, despite the observed increases in military expenditures, many countries in the sub-continent still lack the capacity to protect their own territories from either foreign aggression (for example in the DRC) or from domestic insurgencies (for instance in Central African Republic, the DRC, Mali, and Nigeria). ${ }^{7}$

On the other hand, poverty is widespread all over Sub-Saharan Africa. For instance, statistics from the World Bank's Development Indicators show that, in 2015 under-five mortality

\footnotetext{
${ }^{7}$ Since 2011, numerous armed groups have been challenging state authority in Central Africa Republic (see Kłosowicz,2016). Similarly, from 1996 to date, national and foreign armed groups are still operating in eastern Congo and the government has failed to dismantle them. In Nigeria, the government has not succeeded yet to eradicate Boko Haram, a terrorist Islamist group that has extended its terrorist activities in Cameroon and Chad (see Afoaku, 2017).
} 
and maternal mortality were, respectively 78.3 per 1,000 births and 547 per 100,000 live births. Moreover, only 38 percent of the population have access to electricity, while only 24 percent of people use safely managed drinking water services. Furthermore, SSA lacks adequate infrastructure to support economic growth. Roads, telecommunications, and energy infrastructure are lacking in most of countries, consequently hindering the development of a successful private sector, which is the main driver of economic prosperity. With such enormous development challenges, increases in military expenditures, whether for the purchases of arms and ammunitions or provision for the military apparatus, represent a particularly serious diversion of resources from development priorities.

Striking the balance between development and security is assisted, some might argue distorted, by the role of foreign assistance. Hence, another reason that makes the study of the determinants of military expenditures in Sub-Saharan Africa compelling is the region's reliance on foreign assistance for development. The SSA region remains the major recipient of foreign aid disbursed by donors. To illustrate, over the period of 2007-2016, SSA received US\$ 239.7 billion of ODA, which amounts to 28.1 percent of total ODA disbursed to all developing countries (OECD Statistics) ${ }^{8}$. Over the same period, four of the ten top country-recipients of foreign assistance were in SSA (Cote d'Ivoire, Ethiopia, Kenya, and Tanzania) ${ }^{9}$. It is important to emphasize that foreign development assistance to SSA is an important source of revenue for recipient countries. For example, statistics on aid show that over the period of 2000-2016, the proportion of Net ODA to Gross National Income (GNI) that SSA as a whole received from donors amounted to 4 percent (see World Bank Development indicators databank on Net ODA).

\footnotetext{
${ }^{8}$ See OECD Statistics, available at https://public.tableausoftware.com/views/AidAtAGlance/DACmembers?:embed=y\&:display count=no?\&:showVizHome=no\#1 ${ }_{9}$ In the year 2016 alone, 8 of 10 top ODA recipient countries were in Sub-Saharan Africa (The DRC, Ethiopia, Kenya, Mozambique, Nigeria, South Sudan, Tanzania, and Uganda). See OECD Aid to Africa at http://www.oecd.org/dac/financingsustainable-development/development-finance-data/Africa-Development-Aid-at-a-Glance-2018.pdf
} 
Even though in many fundamental ways security and development are complementary and mutually reinforcing, in discussions of resource allocation in Africa, particularly in SSA, they are more often framed as being in conflict. The external community has expressed strong views on military expenditures in SSA, with many observers often coming down strongly in favor of prioritizing development expenditures and emphasizing the need to reduce military spending to a lower level. For instance, Koffi Annan, the former United Nations SecretaryGeneral, recommended to governments of SSA countries to reduce their military expenditures to below 1.5 percent of their GDP and to commit to zero growth in military burden for a period of 10 years (see United Nations, Report of the Secretary-General, UN document A/52/871S/1998/318, 13 Apr. 1998). The rationale for such a recommendation was to underline the importance of promoting development in this poorest region of the world where insecurity tied in part to weak government control of the territory is one of the major causes of under-investment and more generally under-development.

Therefore, in addition to the domestic forces that shape military expenditures, African countries, particularly those in the SSA region, are also particularly vulnerable to external pressures that influence how they approach spending in the security sector.

\section{Literature Review}

Following the seminal work of Richardson (1960) and Benoit (1973 and 1978), various scholars have examined the determinants of military expenditures in both developed and developing countries. Results from such studies are mixed and sometimes inconclusive or statistically insignificant. According to Dunne et al. (2004), the empirical methodology used by researchers as well as the time span of the studies are the reasons for such mixed results. 
Table \# 1 below summarizes the main findings of previous studies on the demand for military expenditures that included African countries in their samples.

There are two groups of studies of the determinants of military spending (Dunne and Mohammed, 1995 and Dunne and Perlo-Freeman, 2003a). The first group focuses solely on security and consists of the arms race models developed by Richardson (1960). These models focus on the military expenditures of potential enemies (or allies) and examine military expenditures in an action-reaction framework. However, Deger (1986), Smith (1989), and Mohammed (1992) have shown that these arms race models have proven empirically unsuccessful in explaining the demand for military expenditures, especially in developing countries (see also Dunne and Mohammed, 1995).

The second group of studies comprises socio-economic, political, and strategic variables (Maizels and Nissanke, 1986; Dunne and Perlo-Freeman, 2003a \&b; Dunne et al., 2008; Gadea et al., 2004; Yildirim and Sezgin, 2005; Collier and Hoeffler, 2006 \& 2007; and Nikolaidou, 2008). The socio-economic variables include population, the level of national income, trade, and foreign aid. The effect of population ${ }^{10}$ on military spending is not clear. On the one hand, some studies found that it is negatively correlated with both the level of military expenditures and military burden (proportion of GDP). Several reasons might explain this finding. First, a large population size offers a security buffer (see Dunne and Perlo-Freeman, 2003a\&b, Dunne et al., 2008; and Wang, 2013). Nevertheless, this hypothesis has not been explored and empirically tested in more detail, making the case for such an investigation interesting. Second, countries with larger populations may face higher demands for civilian consumption rather than security needs (Dunne and Freeman, 2003b; Collier and Hoeffler, 2002

\footnotetext{
${ }^{10}$ The reason why population is included in models of the demand for military spending is that "while defence may be a public good, its consumption is probably not, so it is per capita consumption that matters for welfare" (Smith, 1995, p. 71).
} 
$\&$ 2006). The third reason is that countries with a smaller size of population may have to spend more on high-technology weapons rather than relying on large armies (see Dunne and PerloFreeman, 2003b). On the other hand, its effect has proven to be positive. Wang (2013) explains that the reason for such a positive effect is that a large population makes higher defence spending more affordable and demanded (see also Hill, 1978; Dudley and Montmarquette, 1981).

Regarding the measures of national wealth, research have found inconclusive results. On the one hand, Dunne and Perlo-Freeman (2003a\&b) and Dunne et al. (2008) found that the size of Gross National Product (as a measure of national income) has an insignificant effect on the level of military spending to GDP ratio, i.e. the military burden. On the other hand, Dunne et al. (2008) found GNP to have both a positive and significant effect on military expenditures. Collier and Hoeffler (2007), using Gross Domestic Product per capita as a measure of a country's income, found it to have a positive and significant effect on military expenditures. One possible explanation for this finding is that as countries become richer, their capacity to collect taxes increases with their level of development and will therefore have a surplus of resources to direct toward security.

Foreign aid is another important variable found in the empirical literature on the demand for military expenditures. Maizels and Nissanke (1986) as well as Collier and Hoeffler (2007) found that foreign aid has a positive and significant effect on military expenditure. This finding implies some leakage of foreign aid to military purpose through the government budget of the receiving governments. Collier and Hoeffler (2007) argue that on average, 11.4 percent of development aid leaks into defence budgets in aid recipient countries.

Political factors included in the studies of the demand for military spending focus on the institutional nature of a country's regime, democracy and autocracy (Dunne and Perlo-Freeman, 
2003 a\&b; Collier and Hoeffler, 2007; Dunne et al., 2008). These studies found that the type of political regime is correlated with military spending. In fact, democracy is found to be negatively associated with military expenditures, presumably because of the nature of its polity. Regimes that are democratic, governed by the principles of the rule of law and with greater citizens' participation in the decision-making process, tend to spend less on the military. In contrast, autocracy is positively correlated with military spending. According to Maizels and Nissanke, 1986), autocratic regimes tend to spend more on the military since they rely more on the use of force to suppress internal threats and political dissent. An extension to this argument is the distinction between autocratic leaders who are (or were) in the military, and those who have no such connection. It is very likely that a military ruler may have a particularly strong incentive to prioritize defence spending. Further analysis may be necessary to test this explanation.

Collier and Hoeffler (2006) find that military lobbies also influence the level of military spending in a given country. They argue that since the military retains a significant political influence on the budgetary decisions in most countries, "a higher level of expenditures enables a large size of the military, implying better prospects of promotions, higher salaries and larger bureaucratic empires" (p.10). However, there appears to be less empirical research on the influence of the military on defence budget in sub-Saharan Africa.

Strategic variables comprise external wars, civil wars, external threats, internal threats, security webs, potential enemies and regional security dynamics as captured with the use of regional dummies (see Dunne and Perlo-Freeman, 2003a \& b; Dunne et al., 2008; Collier and Hoeffler, 2006 and 2007). Indicator variables for external and civil wars are used to identify each country's participation in a war. In Dunne and Perlo-Freeman, (2003a\&b), Dunne et al. (2008), and Collier and Hoeffler (2007), external war is treated as a dummy variable that takes a value of 
1 if a given country has been involved in an international war and zero otherwise. In these studies, it is revealed that (not surprisingly) participation in a war is positively correlated with military spending. For instance, Collier and Hoeffler (2006) reveal that a civil war raises military spending by about 1.8 percent of the country's GDP.

In contrast, the civil war variable is measured differently. In Dunne and Perlo-Freeman (2003a\& b) and Dunne et al. (2008), it is defined as an index variable that ranks from 0 to 4 for each country-year, using conflict databases. Level zero simply means an absence of militarized confrontation between two armed groups or an armed group with a non-violent group such an opposition; whereas level 4 means a generalized civil war. In contrast, Collier and Hoeffler (2007) treat civil war as a dummy variable taking the value of 1 if a country faced an internal conflict that caused at least 1,000 battle deaths per year over the duration of the conflict and zero otherwise. Regardless of how this variable is measured, research shows that it has a positive and significant effect on the level of military expenditures.

In other work, Collier and Hoeffler (2006) define the internal threat variable as the predicted probability of a civil war breaking out. They provide in their study a detailed methodology measuring this probability. They found that it has a positive and significant effect on military spending. They reveal that countries facing a 30 percent risk of civil war during the coming five years are likely to increase their military spending by 1.2 percent of GDP in comparison to a similar country that does not face the same risk. Moreover, they find that an active civil war raises the military expenditures by 1.8 percent of GDP.

Another strategic variable found in the literature is labeled the "security web", a concept developed by Rosh (1988) that captures the effect on a country's military spending of security threats arising from a neighbourhood. According to Rosh, security threats are posed by 
neighbouring countries and as such security is the most important factor determining a country's military expenditures. It is thus the fear of external security threats that compels policy makers in a given country to monitor the level of military spending in their neighbourhood. The reason for such monitoring is that governments are uncertain about the behaviour of their neighbours, whose military spending may be perceived as a security threat, thereby leading to the increase of their own military burden (security dilemma problem). Dunne and Perlo-Freeman (2003a) use different techniques to measure the effect of the security web along with potential enemies (countries with a higher potential for conflict within a security web) on military spending in a given country. Using static panel data, they found that the security web has an insignificant effect but that the presence of potential enemies has a significant effect. In contrast, when using dynamic panel regressions, they found both variables to be positive and statistically significant. Despite this finding, research is not clear as to whether the sensitivity of military spending depends on the relative size of the neighbour and the home country. Therefore, this gap needs more empirical testing to uncover the direction of causality and the exact nature of the association between spending and threat. A caveat is worth pointing out regarding the measurement of the security web. In Dunne and Perlo-Freeman (2003b), it is defined as the total military spending within the web, but not as the average of countries' military spending (in proportion of GDP) as defined in Collier and Hoeffler (2007). The definition adopted by Dunne and Perlo-Freeman has the advantage of being a better proxy for the security threat posed by neighbouring countries. They argue that average defence spending capture only countries' efforts in developing their respective militaries. In contrast to Dunne and Perlo-Freeman, Collier and Hoeffler (2007) use another approach to measure the impact of the security web on military spending. They distinguish between a neighbourhood threat and an emulation variable. They 
define the neighbourhood threat variable as the sum of a given country's neighbours' military expenditures divided by the home country's GDP. In contrast, the emulation variable is in accordance with Rosh's (1988) security web definition. In Collier and Hoeffler (2007), only the emulation variable is significant, not the neighbourhood variable. They argue that the level of security is better captured by both external and internal variables, rendering thereby insignificant the effect of the neighbourhood variable.

Table \# 1. Determinants of Military Expenditures: An Overview of the Literature

\begin{tabular}{|c|c|c|c|}
\hline \multicolumn{4}{|c|}{ Paper \# 1 Dunne and Mohammed (1995) } \\
\hline $\begin{array}{l}\text { Region } \\
\text { and Period }\end{array}$ & Methodology & Independent Variables & Effects of IV on the DV \\
\hline $\begin{array}{l}\text { Sub- } \\
\text { Saharan } \\
\text { Africa }(13 \\
\text { countries) } \\
\\
1967-1985\end{array}$ & $\begin{array}{l}\text { Various } \\
\text { techniques: } \\
\text { OLS, Cross- } \\
\text { Section and } \\
\text { Pooled Time- } \\
\text { series data } \\
\text { analysis }\end{array}$ & $\begin{array}{l}\text { GDP per capita; } \\
\text { government spending/GDP; } \\
\text { trade/GDP, armed } \\
\text { forces/population; military } \\
\text { regime dummy; civil war } \\
\text { dummy }\end{array}$ & $\begin{array}{l}\text { Model 1: GDP per capita (-); Lagged } \\
\text { GDP/Cap (+); Govt Spending to GDP (-); } \\
\text { Trade (-). Military regime and Civil War: }+ \\
\text { but insignificant. } \\
\text { Model 2: GDP per capita }(+) \text { but } \\
\text { insignificant; government spending/GDP } \\
(+) \text {; armed forces/population }(+) \text {; trade }(-) \text {. } \\
\text { Model 3: GDP per capita }(+) \text {; armed } \\
\text { forces/population }(+) \text {; civil war }(+) \text {; } \\
\text { military regime and trade }+ \text { but } \\
\text { insignificant. }\end{array}$ \\
\hline \multicolumn{4}{|c|}{ Paper \# $2 \quad$ Collier and Hoeffler (2002 and 2007) } \\
\hline $\begin{array}{l}\text { Developed } \\
\text { and } \\
\text { developing } \\
\text { countries } \\
1960-65 \\
1995-99\end{array}$ & $\begin{array}{l}\text { Pooled cross- } \\
\text { section data }\end{array}$ & $\begin{array}{l}\text { Population, external war } \\
\text { dummy; civil war dummy; } \\
\text { external threat dummy; } \\
\text { probability of civil war } \\
\text { outbreak; military spending } \\
\text { by neighbours; democracy; } \\
\text { GDP per capita; 1995-9 } \\
\text { dummy; Israel dummy; } \\
\text { Aid/GDP ratio }\end{array}$ & $\begin{array}{l}\text { All variables significant at } 10 \% \text {. } \\
\text { International war }(+) \text {; civil war }(+) \text {; } \\
\text { External threat }(+) \text {; neighbours' military } \\
\text { expenditures }(+) \text {; population }(-) \text {; internal } \\
\text { threat }(+) \text {; GDP per capita }(+) \text {; Democracy } \\
(-) \text {; Israel }(+) \text {; Foreign aid: positive, but not } \\
\text { significant. }\end{array}$ \\
\hline \multicolumn{4}{|c|}{ Paper \# $3 \quad$ Dunne and Perlo-Freeman (2003a) } \\
\hline $\begin{array}{l}\text { Developing } \\
\text { countries } \\
\text { During Cold- } \\
\text { War (1981- } \\
1988) \\
\text { Post CW } \\
(1990-1997)\end{array}$ & $\begin{array}{l}\text { Cross-section } \\
\text { data analysis } \\
\text { Log-linear } \\
\text { model }\end{array}$ & $\begin{array}{l}\text { Population; GNP; external } \\
\text { war dummy; civil war } \\
\text { dummy; military spending } \\
\text { by neighbours, potential } \\
\text { enemies, and enemies } \\
\text { (three variables); Great } \\
\text { power enemy dummy; } \\
\text { democracy score; Middle } \\
\text { East dummy; China } \\
\text { proximity dummy. }\end{array}$ & $\begin{array}{l}\text { External War }(+ \text {, but insignificant in post } \\
\text { Cold War period); Civil War }(+) \text {; log } \\
\text { population }(-) ; \log \text { military spending by } \\
\text { neighbours }(+) \text {; log military spending of } \\
\text { potential enemies }(+) \text {; log military spending } \\
\text { by enemies }(+) \text {; democracy }(-) \text {; } \\
\text { China-dummy }(+) \text {; Middle-East dummy } \\
(+) \text {; Great Power enemy (-); Log GNP (- } \\
\text { but insignificant). }\end{array}$ \\
\hline
\end{tabular}




\begin{tabular}{|c|c|c|c|}
\hline \multicolumn{4}{|c|}{ Paper \# 4, Dunne and Perlo-Freeman (2003b) } \\
\hline \multirow[t]{2}{*}{$\begin{array}{l}\text { Developing } \\
\text { Countries } \\
(1991-1997)\end{array}$} & \multirow[t]{2}{*}{$\begin{array}{l}\text { Panel data } \\
\text { analysis } \\
\text { Arellano \& } \\
\text { Bond (1991) }\end{array}$} & \multirow{2}{*}{$\begin{array}{l}\text { Model 1: External war } \\
\text { dummy; civil war dummy; } \\
\text { Great Power Enemy } \\
\text { dummy; GNP; population; } \\
\text { Trade; military spending by } \\
\text { potential enemies; military } \\
\text { spending by neighbours; } \\
\text { democracy . } \\
\text { Model 2: Excludes the } \\
\text { security-web of non-hostile } \\
\text { countries and use military } \\
\text { spending by enemies. }\end{array}$} & $\begin{array}{l}\text { Fixed-Effects: } \\
\text { External war }(+) \text {; Civil war }(+) \text {, Great } \\
\text { Power enemy }(+) \text {; Potential Enemies }(+) \text {, } \\
\text { Log population }(-) \text {; Log GNP }(-) \text {; Log trade } \\
(-) \text {, democracy }(-) \text {, Log military spending } \\
\text { by neighbours }(-) \text {, Other milex }(+) \text {. }\end{array}$ \\
\hline & & & $\begin{array}{l}\text { Dynamic Effect Model } \\
\text { Log population (-); Log trade }(+) ; \text { Log } \\
\text { GNP (-); External war }(-) \text {; Civil war }(+) \text {; } \\
\text { Log military spending by enemies }(+) ; \\
\text { democracy }(-) \text {; Great Power enemies }(+)\end{array}$ \\
\hline \multicolumn{4}{|c|}{ Cases-studies (country levels) } \\
\hline \multicolumn{4}{|c|}{ Paper \# 1 Batchelor, P., Dunne, P., and Lamb, G. (2002) } \\
\hline $\begin{array}{l}\text { South Africa } \\
(1963-1997)\end{array}$ & $\begin{array}{l}\text { OLS } \\
\text { estimations }\end{array}$ & $\begin{array}{l}\text { Log of real military } \\
\text { spending and Log of share } \\
\text { of military spending in } \\
\text { output }\end{array}$ & $\begin{array}{l}\text { UN arms embargo (dummy, -), Angola war } \\
(\text { dummy, +) ANC regime (dummy, -) }\end{array}$ \\
\hline \multicolumn{4}{|c|}{ Paper \# 2, Abdelfattah et al. (2014) } \\
\hline $\begin{array}{l}\text { Egypt } \\
(1960-2009)\end{array}$ & $\begin{array}{l}\text { Dynamic } \\
\text { model, } \\
\text { cointegration }\end{array}$ & $\begin{array}{l}\text { Log of Egypt's military } \\
\text { burden and real military } \\
\text { spending }\end{array}$ & $\begin{array}{l}\text { Lagged military burden }(+) \text {, GDP }(-) \text {, } \\
\text { Israel's military spending }(+) \text {, net export to } \\
\text { GDP }(-)\end{array}$ \\
\hline \multicolumn{4}{|c|}{ Paper \# 3, Barros, P. (2016). } \\
\hline $\begin{array}{l}\text { Angola } \\
(1992-2012)\end{array}$ & ARDL & $\begin{array}{l}\text { Log of Angola's monthly } \\
\text { military spending }\end{array}$ & $\begin{array}{l}\text { GDP/cap (+), DRC's military spending (+), } \\
\text { Congo-Brazzaville's military spending (-), } \\
\text { Oil rent/GDP (+ but not significant). }\end{array}$ \\
\hline
\end{tabular}

Source: Summarized by the Author

\section{Research Gaps}

The studies cited in the previous section have contributed substantially to our understanding of the determinants of military spending in developing countries. Nonetheless, there are still numerous gaps that this research seeks to fill to advance our understanding of military spending in Sub-Saharan Africa.

The first main gap in our knowledge is about the process leading to the determination of the level of and the composition of the defence budget. The studies on the demand for military spending cited above use quantitative methodologies, particularly econometrics, but none has used a qualitative approach to understand how military planners determine the defence budget, what factors they consider in that process, and what expenditures make up the defence budget. 
This research looks at the process in more detail by examining a case-study of Uganda's defence budget.

Second, there has been little investigation of the determinants of military spending for specific countries in the Sub-Saharan Africa region. Apart from Barros's (2016) survey of Angola's defence sector from 1992 to 2012, Abdelfattah et al. (2014) study of Egypt's defence spending and Batchelor, Dunne, and Lamb (2002) study on the demand for military spending in South Africa, I am not aware of any other published study on military spending at country level in Africa. This study fills that gap by examining the drivers of military spending in Uganda. Dune and Perlo-Freeman (2003b) remark that studying individual countries is the best way of understanding changes in military expenditures across time because such expenditures respond differently to changes in variables across-countries and across time.

Third, none of the previous studies has focused on a comprehensive analysis of SubSaharan Africa using the most comprehensive and up-to-date data available. The study by Dunne and Mohammed (1995) is the only one that focused on the SSA region alone, but only studied 13 countries $^{11}$ for the period of 1967-1985. Dunne and Perlo-Freeman (2003a) included 31 SubSaharan African countries in their study of the determinants of military spending in developing countries over two short time periods: during the Cold War (1981-1988) and after the Cold War (1990-1997). In another study, Dunne, Perlo-Freeman, and Smith (2008) included 12 countries of Sub-Saharan Africa, out of 98 countries included in their sample, over the period of 19811997. This study focuses exclusively on the largest sample of SSA countries for which reliable time series data on military spending are available over the period of 1988-2016. A focus on SSA is important given the serious development challenges faced there, the regional emphasis on

\footnotetext{
${ }^{11}$ Including Benin, Central African Republic, Ethiopia, Kenya, Mali, Niger, Rwanda, Somalia, Sudan, Tanzania, Togo, Uganda, and the Democratic Republic of the Congo (then Zaire).
} 
avoiding inter-state wars despite the imposition of problematic borders, and the instability caused by internal security threats and civil wars.

\section{Theoretical Framework and Assumptions}

Research on the demand for military expenditures requires a clear theoretical framework to allow for the specification of causality, functional form, relevant variables, and the testing of implied restrictions (Dunne and Mohammed, 1995). The reason for such an approach is that a well-defined formal model allows the definition of assumptions and testing of hypotheses.

The neoclassical analytical framework considers the state as a rational actor that maximizes a national social welfare function subject to a budget constraint (see Dunne and Mohammed, 1995; Dunne and Perlo-Freeman, 2003a\&b; Collier and Hoeffler; 2004; Dunne, Perlo-Freeman, and Smith, 2008; Markowski and Massimiliano Tani, 2005). Dunne and Mohammed (1995) observe that the national social welfare function can be determined by the state based on citizens' preferences as aggregated through different voting rules. Under this logic, military expenditures are determined by "balancing their opportunity cost and the security benefits they provide" (Dunne and Mohammed, 1995, pp. 334-335). Using this optimization approach yields models based on relative prices, resource constraints, and perceptions of threats.

Much of this information, especially prices, is unavailable or problematic in the SSA context. In examining the demand for military spending in developing countries, their specific nature must be taken into consideration because in many such countries, military expenditures are often generated by the internal logic of the state, independent of economic conditions (Dunne and Mohammed, 1995). First, political structures in Africa often differ from those of the wealthier countries for which these spending models were developed. Many SSA countries have been dominated by authoritarian governments, often with military rulers. This characteristic may 
well dilute the effects of more traditional politics. In addition, several SSA countries suffer from internal divisions that both complicate political discourse and create potentially severe internal security difficulties. Finally, the lower average levels of wealth and income make developmentsecurity trade-offs in SSA more complex. Many of the standard defence expenditure models based on optimizing behavior will work poorly at boundaries or thresholds where basic survival introduces discontinuities in smooth, twice differentiable utility functions.

This is not to say that studies using these models cannot yield insights for analyzing defence spending in Africa. Given the data limitations for these cases, however, it does not seem worthwhile to try and extract more nuances from these models for the analysis here. Instead, I build on the insights of these models that have informed previous empirical research, and add insights that are appropriate for policy studies and for Africa. The first consequence is that the study here focuses on the level of military spending rather than other measures such as the military burden (defence spending as a proportion of aggregate income) ${ }^{12}$. This focus reflects the reality of policy discussions in which the budget-making process targets spending, not spending as a share of the budget or of income. The second consequence is that the construction and interpretation of key variables, such as security threats, is undertaken with sensitivity to the SSA context. Different types of political regimes or the presence of military leaders may imply an understanding of what constitutes a security threat that differs from what might be observed in more stable democratic settings. Internal security threats may play a particularly important role in SSA, while external threats need to reflect the sub-regional dynamics that dominate the SSA security environment.

\footnotetext{
${ }^{12}$ I follow Sandler and Hartley (1995) who emphasize that, if the objective of the research is to estimate the demand function of military spending (which is the case of this study), then the level of military spending is the appropriate dependent variable, rather than military burden.
} 
Consequently, the analysis in the thesis is guided by a few basic assumptions and expectations. These are often formalized as hypotheses, especially in chapters 2 and 3 where there are specific statistical tests of significance. The first two substantive chapters deal with Uganda, which offers a specific case to identify the details of budgetary processes and concepts of security threats. In general, there is a presumption that regime stability is the primary consideration in determining the level of defence spending in Uganda, and that there are both domestic and internal security threats as well as external risks generated by the sub-regional "security web". In addition, in the Ugandan case, the budgetary process - while systematized will be tightly controlled by the President given the nature of the regime and the fact that he rose to power as the military leader of the victorious side in the civil war.

Given the importance of civil conflict in many SSA countries, including Uganda, the assumption I take to the study is that internal unrest will play an important role in defence spending. The more internal violence there is, or if a full-blown civil war is in progress, I expect that Uganda's military budget will also rise.

In addition to domestic security threats, Uganda is located in a volatile sub-region of SSA. Several neighboring states have experienced civil wars in which Uganda has been implicated or involved (Sudan, South Sudan, Rwanda and DRC), while others have faced threats emanating from other states, such as Kenya's exposure to the risks emerging from the breakdown of order in Somalia. Following from the existing literature on defence spending, I expect to see a positive relationship between military spending in neighboring states and that of Uganda. This relationship captures the notion of the "security web" in order to account for regional security dynamics in contemporary Sub-Saharan Africa. Dunne and Perlo-Freeman (2003a) define a country's security web as "all other countries capable of significantly affecting 
country X's security" (p. 28). Many external factors may affect a country's security. For instance, civil wars in the neighborhood may cause refugee inflows, increasing competition over scarce resources such as land, food and water. Refugees' camps can also be sanctuary for rebel recruitment, drugs and arms trafficking, all of which are illegal activities that require the host country to increase its policing efforts to avoid insecurity. Moreover, state fragility and an ensuing lack of state authority in a neighbour may jeopardize a country's domestic security. A domestic rebel group may take advantage of the absence of state authority next door and use it as a safe haven or base from which to threaten and attack a country. A positive correlation between a country's defence budget and military spending by its neighbours (individually or collectively) may also be an indication of emulation, arms race, or common threats from regional sources. In the Uganda case study, I examine both collective military spending by neighbouring countries, as well as investigate the relationship with individual states. In the larger panel study of several SSA states, I focus on the generalized version of the security web variable and add up the military spending by neighbours.

While the focus of this thesis is on notions of security and how they may affect military spending in SSA, the analysis also affords the opportunity to investigate the role of other factors, including political economy variables. The first of these is the political structure of the country, noting that past research has often found that autocratic regimes spend more on the military than do democratic regime (Maizels and Nissanke 1986; Looney 1988; Rosh 1988; Hewitt 1992; Dunne and Perlo-Freeman 2003; Goldsmith 2003; Fordham and Walker 2005; Acemoglu, Ticchi, and Vindigni 2010). I use the Polity2 index of the Polity IV project, which ranges from a low of -10 (most extreme institutionalized autocracy) to a high of 10 (most extreme institutionalized democracy). The proposed reason why autocrats spend more on the military 
than democrats do is that the former lack popular legitimacy and rely on force to suppress dissent, while the latter are accountable to their public who demand more social spending than defence expenditure. Moreover, Bueno de Mesquita, Siverson, and Smith (1999) found that autocrat rulers are less risk-averse regarding wars or military confrontations than democratic rulers are. Given the failures of democratic process and lack of democratic institutions in many SSA countries, the prominence of neo-patrimonial structures and of centralized states (Adebayo, 2012 and Cheeseman, 2015), it is relevant to include the polity2 variable to account for its potential effect on defence budget.

I also examine the role of development assistance. In some ways, this variable captures a key aspect of the security-development dilemma for resource allocation. On the one hand, more development assistance provides additional budgetary resources for the state to use, and assuming that security and defence constitutes a "normal good" from the government's perspective there is an expectation that military spending will increase as ODA inflows increase. On the other hand, donors, especially traditional donors that are members of the Development Assistance Committee of the Organisation for Economic Co-operation and Development, often object to the expansion of defence budgets by aid recipients. In some instances, they attempt to limit the extent to which resources are shifted from development priorities to security using conditionality backed up by the threat of withdrawing financial support. Which of these two impulses dominate in SSA is unclear. While SSA countries often suffer severe resource constraints, they are also often more susceptible to pressure from the ODA donors upon whom they rely for financial assistance.

Other political economy variables that I test include the incidence of coups and the presence of heads of government who have a military background. State rulers drawn from the 
military may be expected to lavish more spending on defence, though of course they may also be able to use their military credentials to resist such spending. Which pressure dominates may well depend on the leader's political strength and the degree to which they rely on military support for maintaining their position of power. Coups are even more complex. The issue of timing is critical, as a coup may alter the level of military spending the year that it occurs. Low military spending could trigger a subsequent coup, though the threat of a coup may also motivate a government to increase defence spending in an attempt to placate the military. At best, I hope to discover if any correlation exists at all, leaving the more complex question of causality to future researchers.

\section{Thesis Structure}

This dissertation comprises three substantive chapters. The first one examines qualitatively the process for determining the defence budget in Uganda, relying on key informant interviews and supporting documents. The choice of Uganda as the case study is explained in detail in the next chapter, but it has many useful characteristics: a long history of both internal and external conflict, located in the volatile Great lakes sub-region, and with a government and President that has been in power for over 30 years. The second chapter extends the analysis of Uganda by using time series quantitative analysis to examine the determinants of military spending. The dynamic quantitative model adds value because of the non-stationarity of the time series data used in the model. These first two chapters complement each other by comparing the qualitative and quantitative results to see to what extent they agree or differ in their findings. The final chapter uses panel-data econometrics to examine the level of military spending in a large group of sub-Saharan African countries. The analysis of this larger sample is informed by the 
earlier chapters on Uganda and provides an opportunity to examine an important element of the security-development dilemma in this is critical region of the world. 


\section{References}

Chan, S. (1988). "Defense burden and economic growth: Unraveling the Taiwanese Enigma." The American Political Science Review, Vol. 82, No. 3, pp. 913-920

Collier, P. and Hoeffler, A. (2002). "Military Expenditures: Threat, Aid and Arms Race”, World Bank, Working Paper No.2927 (November), accessed at http://elibrary.worldbank.org/doi/pdf/10.1596/1813-9450-2927

Collier, P. (2006). "War and Military Expenditures in Developing Countries and their Consequences on Development", The Economics of Peace and Security Journal, Vol. 1. (1), pp. $10-13$

Collier, P. and Hoeffler, A. (2007). "Unintended Consequences: Does Aid Promote Arms Race?" Oxford Bulletin of Economics and Statistics, Vol.69 (1), pp. 0305-9049

Chowdhury, Abdur. (1991). "A Causal Analysis of Defense Spending and Economic Growth", Journal of Conflict Resolution, Vol. 35 (1): pp. 80-97

Deger, S. and Smith, P. (1983) "Military Expenditure and Growth in Less Developed Countries," Journal of Conflict Resolution, Vol. 27(2): pp. 335-353.

Dommen, E. and Maizels, A. (1988). 'The Military Burden in Developing Countries,' Journal of Modern African Studies, Vol. 26(3): pp. 377 - 401

Dunne, P. and Mohammed, N. (1995). "Military Spending in Sub-Saharan Africa: Some Evidence," Journal of Peace Research, Vol. 32 no. 3, pp. 331-343

Dunne, P. (1996) "Economic Effects of Military Expenditure in Developing Countries: A Survey', in Gleditsch et al. (edited) Contributions to Economic Analysis, Vol. 235, (Oxford: Elsevier, North-Holland): pp. $439-464$.

Dunne, P. and Perlo-Freeman, S. (2003). "The Demand for Military Spending in Developing Countries: A Dynamic Panel Analysis," Defence and Peace Economics, Vol.14, Issue 6, pp.

Dunne, P. and Perlo-Freeman, S. (2003). "The Demand for Military Spending in Developing Countries," International Review of Applied Economics, Vol. 17, Issue 1, pp.

Dunne, P. and Perlo-Freeman, S. and Smith, R. (2008). "The Demand for Military Expenditure in Developing Countries: Hostility versus Capability," Defence and Peace Economics, Vol. 19, Issue 4, pp.

Faini, R., Annez, P. and Taylor, L. (1984) "Defense Spending, Economic Structure and Growth: Evidence among Countries and Over Time', Economic Development and Cultural Change, Vol. 32(2): pp. $487-498$.

Gadea, D., Pardos, E., and Perez-Fornies, C. (2004). "A Long-Run Analysis of Defence spending in the 
NATO Countries (1960-99),” Defence and Peace Economics, Vol.15, Issue 3, pp.231-249.

Smith, R. (1995). “The Demand for Military Expenditure”, in Harley, K. and Sandler, T. (eds.), Handbook of Defense Economics (Amsterdam: Elsevier), pp. 70-87

Richardson, L. (1960). Arms and Insecurity: A Mathematical Study of the Causes and Origins of War (Pittsburgh, PA: Homewood). 


\section{Chapter 1. The Study of the Military Budget in Uganda}

\subsection{Introduction}

Conducting research on military budget is often a difficult task because of the secrecy surrounding the defence sector. Often accurate information on military spending is classified and not publicly accessible. As a result, there is a scant discussion on the process of creating and approving the defence budget in the academic literature on military spending in developing countries. Most studies use quantitative analysis to examine the factors that influence the demand for defence spending in those countries (Fredrickson and Looney, 1986; Dunne and PerloFreeman, 2003a and 2003b; Dunne, Perlo-Freeman, and Smith, 2008; Abdlefattah et al., 2014), but those studies overlook the analysis of both the process and structure of the defence budget. This paper fills that gap by examining the process leading to the determination of the military budget drawing on Uganda as a case-study.

Uganda is a landlocked country in Eastern Africa. It is an interesting case study for three main reasons. First, it has a long history of civil wars and military coups, and the military elite has often exerted substantial control or influence over the political system (Ravenhill, 1974; Decalo, 1990; Omara-Otuunu, 1987 and 1998; Twaddle and Bernt Hansen, 1998; KiyagaNsubuga, 1999; Tangri and Mwenda, 2003 \& 2010; Rubongoya, 2007; Hayness, 2007; Carbone, 2008; Kobusingye, 2010; Tripp, 2010, Kagoro, 2013ab \& 2015; Otunnu, 2017). Second, Uganda has a strong military presence in regional conflicts, whether in the central Africa region or in the Horn of Africa (see Reno, 2002; Prunier, 2004 and 2009; and Karungi, 2011). Its interventionist foreign policy in such conflicts as those Burundi, the Democratic Republic of Congo, Somalia and South Sudan has put pressure on its military budget. Third, Uganda has been one of the major beneficiaries of foreign aid in Sub-Saharan Africa. Over the period of 1985 to 2015, it received an average of \$US 1.12 billion of net official development assistance (World Bank 
Development Indicators) ${ }^{13}$. This amount represents an average of $3.8 \%$ of all net ODA received by the SSA over the same period, which is very close to Uganda's $4 \%$ share of the population of SSA (World Bank's Development Indicators, 2016).

The objective of this paper is twofold. First, it aims to comprehend not only the process of the formulation of Uganda's defence budget and its structure, and the actors involved in that process and, more importantly, to understand which of those actors has the final decision over the level of the defence budget. Two advantages emerge from such an analysis. First, given the secrecy typically surrounding defence expenditures, the paper the extent to which there is transparency in the defence budget process. The military sector, as with any other government department, should not be immune to the governance principles of public finance, and the government should be held accountable for the management of scarce public money it allocates to the defence sector (Gupta, de Mello, and Sharan, 2002). Second, the analysis shows the bargaining power of the national actors involved in the budget process, specifically the civilmilitary power relationship. Understanding the bargaining of power helps determine who has the final decision on the level of the defence budget.

The second objective of the paper is to examine the security threats - internal and external -- that Uganda faces in the short and medium terms and that military planners take into consideration in the preparation of the defence budget. In so doing, I follow MacDonald's (1997) approach of security threats analysis in his study of military spending in developing countries. The linkage between the process of creating the defence budget and threats assessment is evident because understanding the process leading to the determination of military spending is contingent upon the understanding the nature of security threats the country faces or is likely to

\footnotetext{
${ }^{13}$ See Net official development assistance received (constant US\$ 2015), World Bank Development Indicators, retrieved at http://databank.worldbank.org/data/reports.aspx?source=world-development-indicators\#
} 
face in the short, medium or long term, and the role the military should play in addressing those threats. In fact, studying security threats is important because research has shown that their nature is a predictor of how military expenditures are determined. Dowdle (1992) found, for instance, that in African nations, an internal active threat such as a civil war greatly influences the military budget because of the risk it poses to the survival of the regime. Additionally, a clear understanding of the linkage is an important element of the principle of adequacy of resources and threats because it allows for a successful acquisition of military capability and recruitment of manpower, both of which are crucial elements of military spending, and thereby enables the military to fulfill its mission of protecting the country against foreign aggression (see MacDonald, 1997).

This chapter is organized as follows. Section 1 presents the research methodology, while section 2 discusses the process and structure of creating the military budget in Uganda. Section 3 discusses the external and internal security threats facing Uganda and Section 4 concludes.

\subsection{Research Methodology}

I used a qualitative approach to gather data for the analysis of this study. Denzin and Lincoln (2011) explain that a qualitative approach is a situational activity involving an interpretive and naturalistic approach to the world. They point out that the benefit of this approach is that it allows researchers to examine the subjects of the study in their natural settings, attempting thereby to make sense of them or interpret phenomena in terms of the meaning people bring to them.

Two reasons made this approach suitable for this study. First, as an evaluative research, the study is primarily concerned with how the dynamic of formulating the defence budget works. Ritchie and Ormston (2003) teach that "in order to carry out an evaluation, information is needed 
about the process and the outcomes and qualitative research contributes to both" (p. 33). The second reason is the sensitivity of the topic and the need to get people's explanations and perceptions of the subject being examined. Hennink et al. (2011) observes that researchers need a specifically defined approach to uncover the evidence sought by the study. In a country like Uganda that has a long history of civil wars and where the military influences the political system through its embeddedness with the ruling party, statistics on the defence budget alone are not enough to understand the whole story behind military expenditures. As Palys (2003) writes, "validity requires intimacy," which means, "understanding people's perceptions requires getting close to research participants or informants or collaborators" (p. 11). Talking directly to respondents, specifically to military officials who have deep knowledge of Uganda's defence sector was therefore crucial. Their perceptions of Uganda's national security and defence sector helped shed light on what is important for the defence budget. This insight is not captured directly through the examination of statistics of the defence budget.

I gathered the information that forms the basis of this chapter through structured interviews I conducted during the fieldwork in Kampala (Uganda's capital city) from July 21 to August 22, 2016. The purpose of the fieldwork was to get firsthand information on both the process of and the security threats that influence the defence budget in Uganda from defence experts and technocrats who have deep knowledge of Uganda's security environment. In addition to the sensitivity of the subject of the research, I chose the interview approach because of its numerous advantages. It allows for a dialogue between the researcher and the respondents, a clarification of any confusion about some questions being asked, and the possibility of building a long-term relationship with respondents (see Palys, 2003: 149-159). 
During the fieldwork, I conducted 30 interviews with research participants, including: i) junior and senior commanders of the Uganda People's Defence Forces ${ }^{14}$ (the Ugandan army, hereafter UPDF); ii) members of parliamentary committees on defence and internal affairs, finance, and national economy; iii) academics, iv) public servants; and v) members of the civil society organizations and the media. Most research participants requested anonymity. Figure \# 15 below show the distribution of research participants by profession. Talking to all these people was very beneficial because of their deep knowledge of Uganda's politics and security landscape.

\section{Figure \# 15. Distribution of Research Participants by Profession}

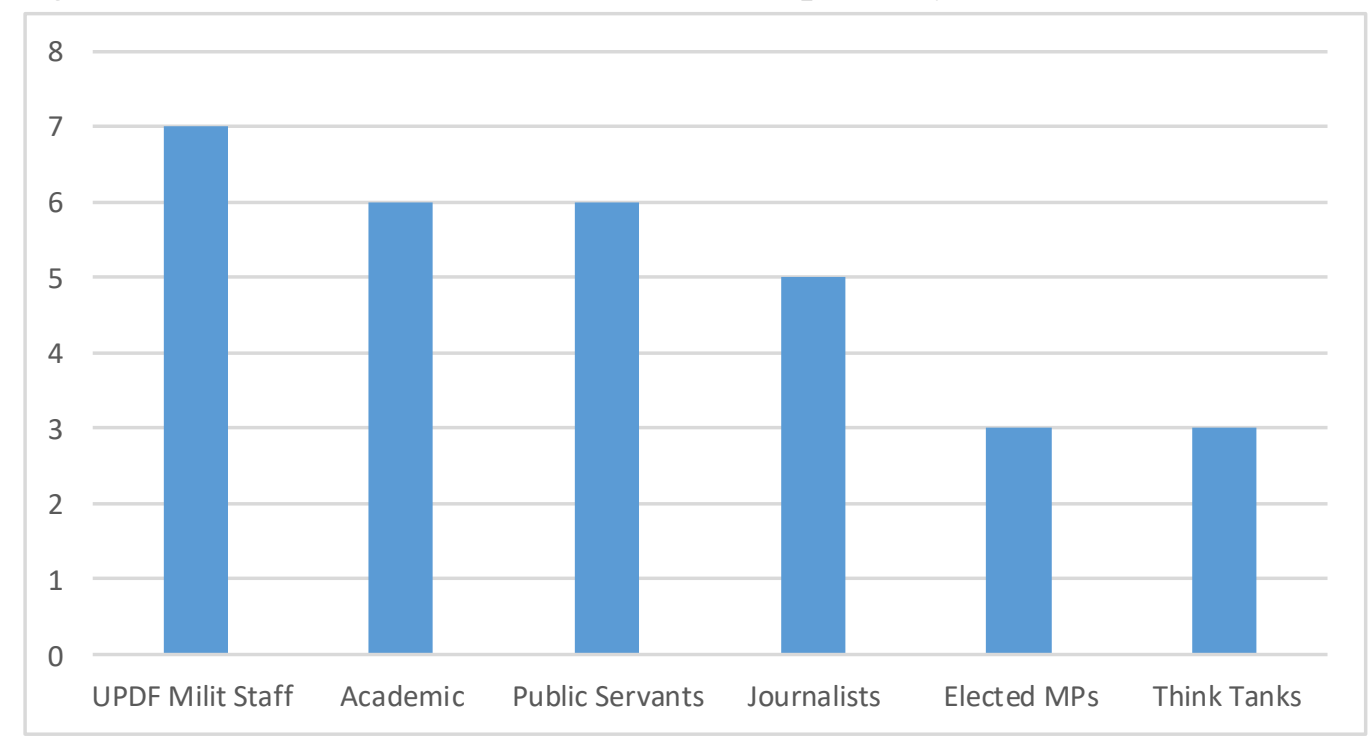

Source: Fieldwork in Kampala, July 21-Augsut 22, 2016.

The figure above shows that the most key informants came from the military, followed by academics and public servants. Journalists also provided very valuable information for this research. $^{15}$

\footnotetext{
${ }^{14}$ The average number of years in the army for UDPF staff I interviewed is 22 years.

${ }^{15}$ Since I was aware of the relationship between the media and the government, I made extra efforts to corroborate the accuracy of information journalists provided.
} 
From the perspective of research ethics, I must emphasize that the Carleton University's Research Office reviewed the interview materials (questionnaire and consent form) and issued the research ethics clearance. I also received a research clearance from the Office of the President of Uganda as well as from the Ugandan National Council for Science and Technology (UNCST), which is the national institution granting research permits for both nationals and foreign researchers in Uganda. Dr. Charlotte Karungi Mafumbo of Makerere University acted as the research field supervisor and assisted in the identification of research participants, specifically those from the military. She has conducted research on Uganda's security sector and accepted to facilitate my academic project. She introduced me to the Chieftaincy of Military Intelligence (CMI) at the ministry of defence to get the clearance to speak to the military. The CMI reviewed and approved of my research materials and provided names of army commanders I could contact. Non-military participants were identified on a snowballing process. Before traveling to Uganda, I prepared a list of potential research respondents from background materials I consulted on Uganda's security. Dr. Karungi reviewed the list and recommended additional participants. When I approached them, they too recommended other participants whom I could contact because of their expertise on the research topic.

Finally, throughout this study, I use the Stockholm International Peace Research Institute's (SIPRI) ${ }^{16}$ definition of military expenditures. Based on SIPRI's definition, military expenditure data include all current and capital expenditure on: (a) the armed forces, including peacekeeping forces; (b) defence ministries and other government agencies engaged in defence projects; (c) paramilitary forces, when judged to be trained and equipped for military operations; and (d) military space activities. This includes expenditure on: personnel (salaries of military and

\footnotetext{
${ }^{16}$ See details at https://www.sipri.org/databases/milex/sources-and-methods\#definition-of-military-expenditure
} 
civil personnel, retirement pensions of military personnel, and social services for personnel); operations and maintenance; procurement; military research and development; military infrastructure spending, including military bases; and military aid (in the military expenditure of the donor country). SIPRI exclude such expenditures on civil defence and current expenditures on previous military activities (veterans' benefits, demobilization, conversion and weapon destruction). SIPRI provides estimates on military expenditures in local currencies, in real \$US values (i.e. constant US dollars), as a percentage of GDP and per capita. The coverage of SIPRI's figures is comprehensive and consistent across countries.

A caveat is noteworthy. Although SIPRI estimates are commonly used, they do not necessarily reflect with complete accuracy the level of military expenditures. Hewitt (1991) points to one major limitation. He argues that, because some countries that receive suppliers' credits and other commercial credits to purchase foreign military equipment fail to report these acquisitions in their defence budgets, one should therefore assume that SIPRI data underreport the purchases of foreign military equipment.

\subsection{The Process and Structure of Military Budget in Uganda.}

The purpose of this section is to explain the process of the military budget in Uganda and to shed light on the structure of that budget. In so doing, the section sheds light on how the defence budget is generated, who is involved in that process, and more importantly, who has the final decision in the process and on the level of defence expenditures, demonstrating thereby the balance of power among national actors who engage in the military budget process. By analyzing the structure of the defence budget, this study contributes to our understanding of military expenditures in Sub-Saharan Africa because that aspect is often overlooked in the academic literature on the demand for military spending, 


\subsubsection{The Process of Generating Uganda's Defence Budget ${ }^{17}$.}

To begin with, it is noteworthy to say that the process of generating the military budget in Uganda is embedded in the legal framework for the national budget process, which is enshrined in the Constitution of 1995, the Local Government Act of 1997, and the Public Finance Management Act (PFMA) of 2015. The budget of the government of Uganda is made of sectoral allocations set by the Ministry of Finance (hereafter MoF) in the Medium-Term Expenditures Framework (hereafter MTEF). The sectoral allocations are derived through a consultative process at national level involving all stakeholders. The preparation of the national budget starts in September of the current year and ends with the Budget Speech, delivered by the MoF at the Parliament in June of the following year. The budget becomes effective on the first of July after its approval by Parliament. ${ }^{18}$

Before the delivery of the Budget Speech, parliamentary committees examine the budget proposal as submitted by the MoF and invite representatives of ministries and national departments under their respective commissions to answer specific questions pertaining to the budget. It is important to mention that during this examination phase of the budget proposal at the Parliament, members of civil society organizations and the media whose work is related to the management of public finances are invited to participate in the process. The participation of civil society organizations, such as the Kampala-based Civil Society Budget Advocacy Group (CSBAG), ${ }^{19}$ signals some sense of citizen engagement in the process as well as some sense of transparency and accountability. Members of civil society organizations who participate in the budget process at parliamentary review stage take an active role in the examination of the budget

\footnotetext{
17 The information described in this sub-section originates from the interviews I conducted during the fieldwork.

${ }^{18}$ It is useful to note that all research participants explained that the level of Uganda's military spending is not determined as a fixed percentage of GDP. This is an important methodological issue, since several quantitative analyses estimate defence spending as a proportion of GDP rather than simply the expenditures themselves.

${ }^{19}$ see more information on this organization at http://csbag.org
} 
proposal and make recommendations for the government to take into consideration in the final budget proposal. The purpose is to guarantee that citizens' demands are taken into consideration in the national budget.

At the Ministry of Defence (hereafter, MoD), the process of generating the defence budget starts in September as well when the MoF launches the process of formulating the national budget by sending a Budget Call Circular (hereafter, BCC) to all ministries and government agencies. The BCC identifies the government policy guidelines for the coming budget and indicative numbers, based on the macroeconomic framework. Based on the BCC, the MoD prepares its Sector Budget Framework Paper (hereafter SBFP) that takes into consideration the defence sector's priorities and demands by stakeholders and submits it to the MoF by November 15.

It is important to understand the internal process within the MoD that leads to the formulation of the defence budget. Internally, the $\mathrm{MoD}$ has what is called the Top Management Committee (TMC). This committee is composed of the most senior policy makers (civilians and military) and defines the Ministry's Strategic Priorities (hereafter, MSP) for the coming financial year. The MSP forms the basis upon which the ministry elaborates its SBFP. The MoD's Chief of Planning and Policy, a military personnel, prepares the MoD's SBFP based on submissions from defence's Chiefs and End users who compile the needs of their respective forces and submit them to the Chief of Planning. The SBFP must be in line with the priorities set by the TMC.

It must be clear that submissions from UPDF's Chiefs and end users are estimates of expenditures gathered by the army's Chiefs (heads of the army's specific wings/departments), following instructions given by the army's Chief of Defence Forces (CDF). The most senior 
policy makers in the MoD and the top commanders of the UPDF discuss the MoD's SBFP during the Budget Conference before they send it to the MoF. The MoD's sectoral budget along with other ministries and agencies' proposals are thereafter consolidated into one national budget framework paper. The MoF, with the approval of the cabinet, then submits the national framework paper (NFP) to Parliament by December 31st.

The Parliament, through its sectoral committees, then reviews and approves the NFP by February of the next year. After Parliament has approved the NFP, the MoD and UPDF senior commanders have to appear before the Parliamentary Committee on Defence and Internal Affairs (PCDIA) to answer the committee's queries on the proposed defence SBFP. The MoD prepares its Ministerial Policy Statement (MPS) to submit to the PCDIA by the 15 th of March. The MPS is the document that forms the basis for the parliament's scrutiny and debate on the defence budget and provides a link between the ministry's strategic priorities and the proposed budget allocations. During these parliamentary meetings, the MoD and UPDF leadership not only answer committee's members' questions, but also seek to persuade them to accept the estimates of the defence sector, based on the security assessment of both internal and external threats as well as based on the UPDF's needs in terms of staff, soldiers, logistics, military intelligence, and other classified operational needs. Classified spending of the defence sector is made of all spending that is pertinent to the defence sector and the stability of the regime, but that cannot be made public.

\subsubsection{On Classified Defence Expenditures}

A brief discussion on classified defence expenditures is necessary. One respondent explained that classified expenditures include such spending as the purchase of strategic weapons, expenditures for military intelligence, financial support provided to armed groups in 
the region that are supported by the UPDF, and other presidential spending deemed secret and thus hidden in the defence budget. Another respondent informed me that classified spending often includes expenditures that are under direct control of the President and which he always gets because he is the Commander-in-Chief. That respondent explained that the defence budget is in fact the "President's personal budget and as such he has the final decision on it and always gets what he wants in it." This claim corroborates what nearly all research participants mentioned about the President's influence over the defence budget.

There is a general agreement among respondents' answers that the President of Uganda has direct influence over the defence budget and the final decision on its level. He is informed of its process at all levels and approves of the final defence budget proposal that is sent to the MoF. No item in the defence budget can be removed or added without his approval. Additionally, some participants revealed that whenever members of the opposition demand cuts in the proposed defence budget, they always fail because other committee members push back. It is worth pointing out here that the NRM, which has been the ruling party since 1986, has always had a majority in Uganda's parliaments under the Museveni regime. NRM members of the Parliament are always supportive of the President's priorities, of which the security sector is the biggest one. In addition, it is important to note that the military's high command designates 10 UPDF commanders (from Colonels to Generals) to be members of the sitting parliament. The military background of the President as well as the demands for the security and stability of his regime make the defence sector his top priority.

After the Parliament has approved the MoD's SBFP, the MoF issues a final Budget Call Circular $(\mathrm{BCC})$ to ministries and agencies with concretized MTEF numbers that will form the final national budget that will be re-examined and approved by the Parliament. Based on the final 
$\mathrm{BCC}$, the MoD prepares and submits its final sectoral budget estimates to the MoF for consideration in the national budget. The MoF consolidates the final budget estimates and presents the budget to the Parliament by April 1st. The Parliament then scrutinizes the budget and approves it by May 31st.

\subsubsection{Structure of Uganda's Defence Budget}

Table 2 below presents the basic structure of Uganda's defence budget for the last eight financial years.

Table 2. Structure of Defence Budget Allocations (Billions, Uganda Shillings)

\begin{tabular}{|l|r|r|r|r|r|r|r|r|}
\hline Category & \multicolumn{1}{|c|}{$2009 / 10$} & \multicolumn{1}{|c|}{$2010 / 11$} & $2011 / 12$ & \multicolumn{1}{|c|}{$2012 / 13$} & $2013 / 14$ & $2014 / 15$ & $2015 / 16$ & $2016 / 17$ \\
\hline Salaries & 200.6 & 244.2 & 265.1 & 325.2 & 338.1 & 388.8 & 388.8 & 410.4 \\
Other Recurrent & 231.8 & 231.8 & 230.1 & 230.1 & 320.1 & 360.2 & 470.3 & 467.4 \\
Development & 25.1 & 137.7 & 442.7 & 348.7 & 347.8 & 356.6 & 701.3 & 614.21 \\
Total Budget & 457.5 & 613.6 & 938.0 & 904.0 & $1,006.1$ & $1,105.6$ & $1,560.4$ & $1,492.0$ \\
\hline
\end{tabular}

Source: Parliament of Uganda, Approved Budgets, Archives (several years)

This table shows that overall, from 2009 to 2016, Uganda's defence budget increased by 226 percent and allocations for defence development recorded the highest increase of 2347 percent. Allocations for salaries and other recurrent increased by 104 percent and 101 percent respectively. Uganda's manpower is estimated to be around 55,000 plus an unknown number of paramilitary forces who are paid from the defence budget. Other recurrent expenditures encompass such expenditures as food, uniforms, medical, housing (military barracks), classified, and pensions. Development expenditures include such spending as military infrastructure, and the production of small arms and ammunitions. ${ }^{20}$ For the purpose of illustration, Tables 3 and 4 show the share of classified expenditures in other recurrent expenditures and the total defence

\footnotetext{
${ }^{20}$ Three research participants revealed that Uganda has a small weapon industry that produces small weapons and ammunitions.
} 
budget, respectively. Clearly, classified expenditures account for the largest share of other recurrent expenditures over the period of 2010-2017.

Table 3. Proportion of Classified Expenditures in Other Recurrent Expenditures

\begin{tabular}{|l|r|r|r|r|r|r|r|r|}
\hline \multicolumn{1}{|c|}{ Category } & $2009 / 10$ & $2010 / 11$ & $2011 / 12$ & $2012 / 13$ & $2013 / 14$ & $2014 / 15$ & $2015 / 16$ & $2016 / 17$ \\
\hline Other Recurrent & 231.8 & 231.8 & 230.1 & 230.1 & 320.1 & 360.2 & 470.3 & 467.4 \\
\hline Classified Exp. & 122.19 & 122.20 & 128.87 & 180.20 & 127.00 & 299.38 & 342.25 & 377.95 \\
\hline \% of Classified Exp. & 52.7 & 52.7 & 56.0 & 78.3 & 39.7 & 83.1 & 72.8 & 80.9 \\
\hline
\end{tabular}

Source: Author's calculation from data collected for Table 2.

Table 4. Proportion of Classified Expenditures in the Defence Budget

\begin{tabular}{|l|r|r|r|r|r|r|r|r|}
\hline Category & $2009 / 10$ & $2010 / 11$ & $2011 / 12$ & $2012 / 13$ & $2013 / 14$ & $2014 / 15$ & $2015 / 16$ & $2016 / 17$ \\
\hline $\begin{array}{l}\text { Total Budget (billions of } \\
\text { Uganda Shillings) }\end{array}$ & 457.5 & 613.6 & 938.0 & 904.0 & $1,006.1$ & $1,105.6$ & $1,560.4$ & $1,492.0$ \\
\hline $\begin{array}{l}\text { Classified } \\
\text { Expenditures (billions of } \\
\text { Uganda Shillings) }\end{array}$ & 122.19 & 122.20 & 128.87 & 280.20 & 127.00 & 299.38 & 342.25 & 377.95 \\
\hline$\%$ of Classified Exp. & 26.7 & 19.9 & 13.7 & 31.0 & 12.6 & 27.1 & 21.9 & 25.3 \\
\hline
\end{tabular}

Source: Author's calculation from data collected for Table 2.

Figure \# 16 shows the trend of defence spending vis-à-vis other ministries' allocations. The Figure shows that until recently defence spending has tended to grow more slowly than other key spending categories. In turn, Figure \# 19 shows the proportion of sectoral allocations in the national budget in different years, and clearly indicates the decline in defence spending from over $17 \%$ of the budget in $1994 / 5$ to under $9 \%$ by $2015 / 16$. 
Figure \# 16. Trend of Defence Allocations vi-a-vis Development Spending

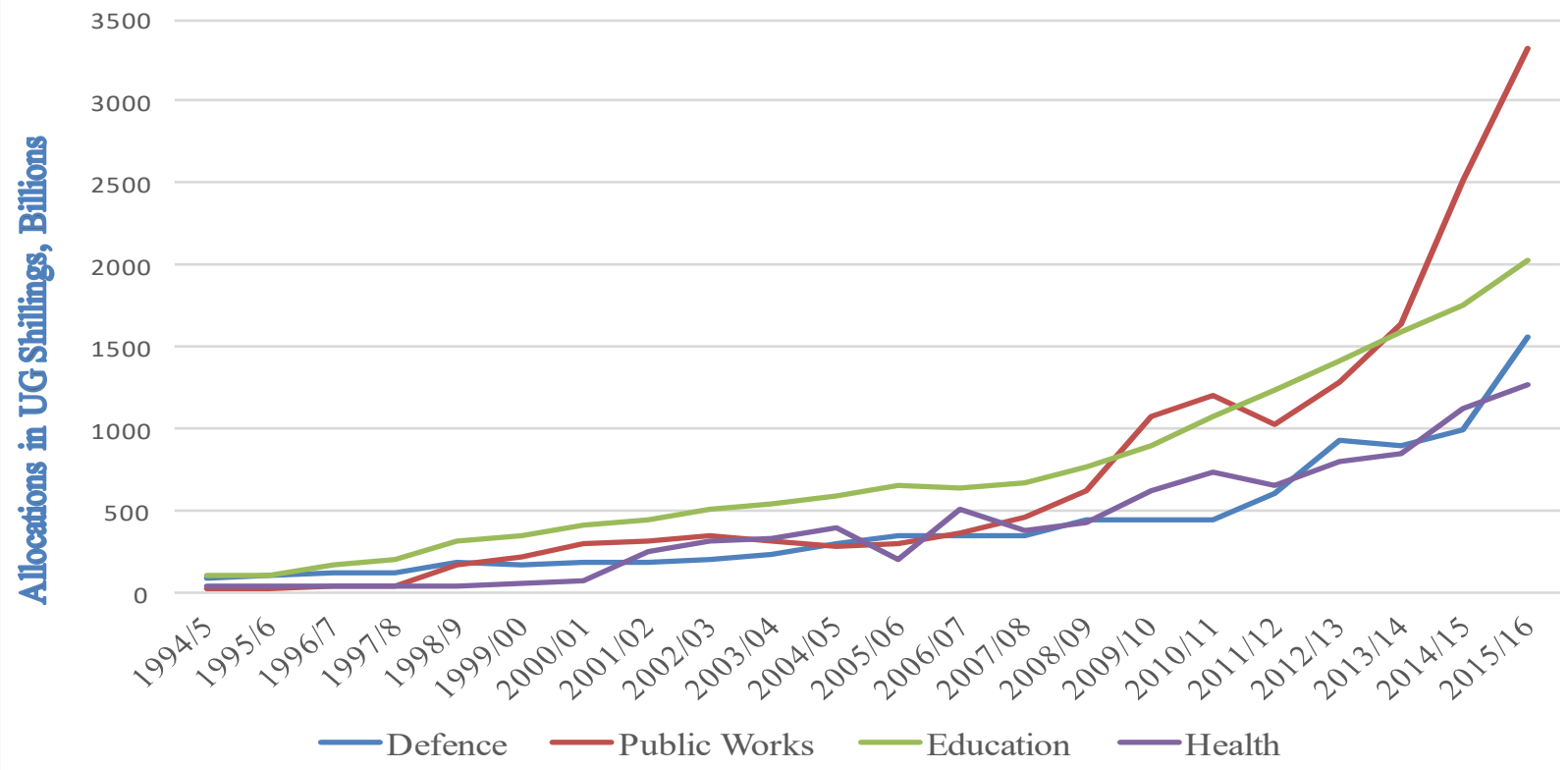

Source: Ministry of Finance, Planning and Economic Development -

Background to the Budget \& Approved Estimates for various Fiscal Years.

Figure \# 17. Proportions of Sectoral Allocations in the National Budget (\%)

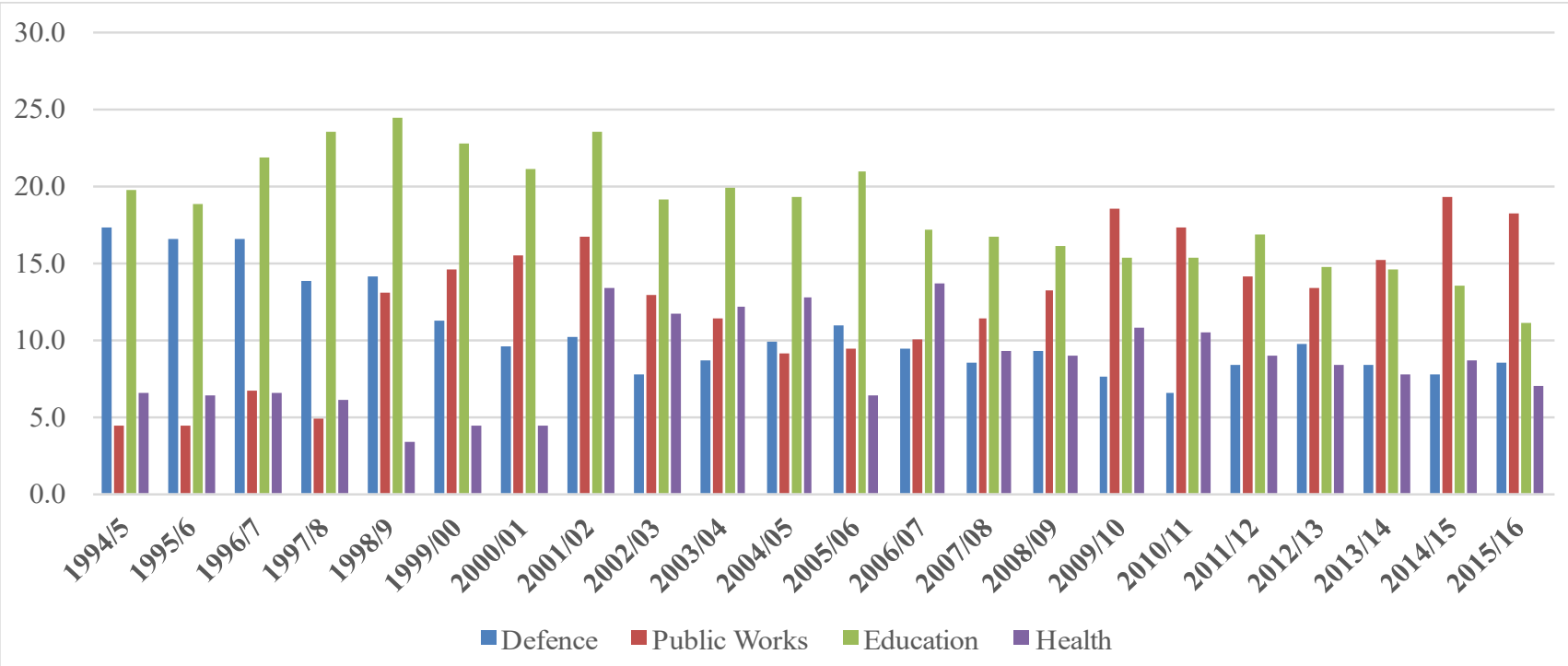

Source: Same as for Figure \# 16.

A key message that arises from Figures 16 and 17 above is that military expenditure in Uganda do not outweigh other development programs and that their share of the national budget 
has been declining over time. ${ }^{21}$ This pattern is contrary to the argument made by some international organizations that developing countries tend to spend more on the defence sector than on development programs. In 1998, Mr. Kofi-Annan, then Secretary General of the United Nations, called on African countries to reduce their purchases of arms and munitions to below 1.5 per cent of their GDP and to commit themselves to zero growth in military expenditure for a period of 10 years (United Nations, Document A/52/871-S/1998/318). The underlying reasoning is that African countries divert resources away from development by spending more on the military sector, thereby impeding efforts for poverty reduction. This argument does not seem as relevant in the case of Uganda, where defence expenditures, though growing, have not kept pace with increased spending in other areas of government activity, including those most associated with development.

\subsection{The Structure and Role of the UPDF}

The Uganda People's Defence Forces (UPDF) constitute Uganda's national army. Per Article 209 of the Constitution of Uganda (1995), the UPDF has the following four functions:

(a) to preserve and defend the sovereignty and territorial integrity of Uganda;

(b) to cooperate with the civilian authority in emergency situations and cases of natural disasters;

(c) to foster harmony and understanding between the defence forces and civilians; and

(d) to engage in productive activities for the development of Uganda.

The UPDF is under the direct authority of the MoD, which is the political entity that oversees all policy matters pertaining to national defence. The MoD has two distinct branches: the civilian branch and the military branch. The civilian branch, which is under the authority of

\footnotetext{
${ }^{21}$ This claim must be taken with caution because Uganda receives military aid from the US and other foreign partners, but those subsidies are directly provided to the $\mathrm{MoD}$, not to the central government. Also, the MoD under-reports its expenditures for secret defence reason. For instance, many research participants pointed out that the budgetary allocations to the defence sector were the highest relative to other sectors between 1997 and 2002 when Uganda invaded and supported rebellions in the Democratic Republic of the Congo. But this is not reflected in the Ministry of Finance Approved Budgets documents.
} 
the "Permanent Secretary" of defence, oversees the ministry's administration, accounting, and finance. The mandate of the civilian branch is to support and facilitate the mission of the armed forces. The UPDF form the military branch and is under the command of the Chief of Defence Forces (CDF). Both the Minister and the Permanent Secretary are civilians appointed by the President with the approval of the Parliament. The CDF is a senior military official (a general) appointed by the President, who can also remove him at any time, depending on internal politics within the army and NRM. Although the CDF oversees the military command and administration of the UPDF, the President remains the Commander-in-Chief, as prescribed by the Constitution of 1995 (chapter 7, section 98.1). The UPDF comprises the land forces, air forces, as well as two small departments of navy and marines. ${ }^{22}$ Figure 18 below shows the structure of the MoD.

Figure \# 18. The Structure of Uganda's Ministry of Defence

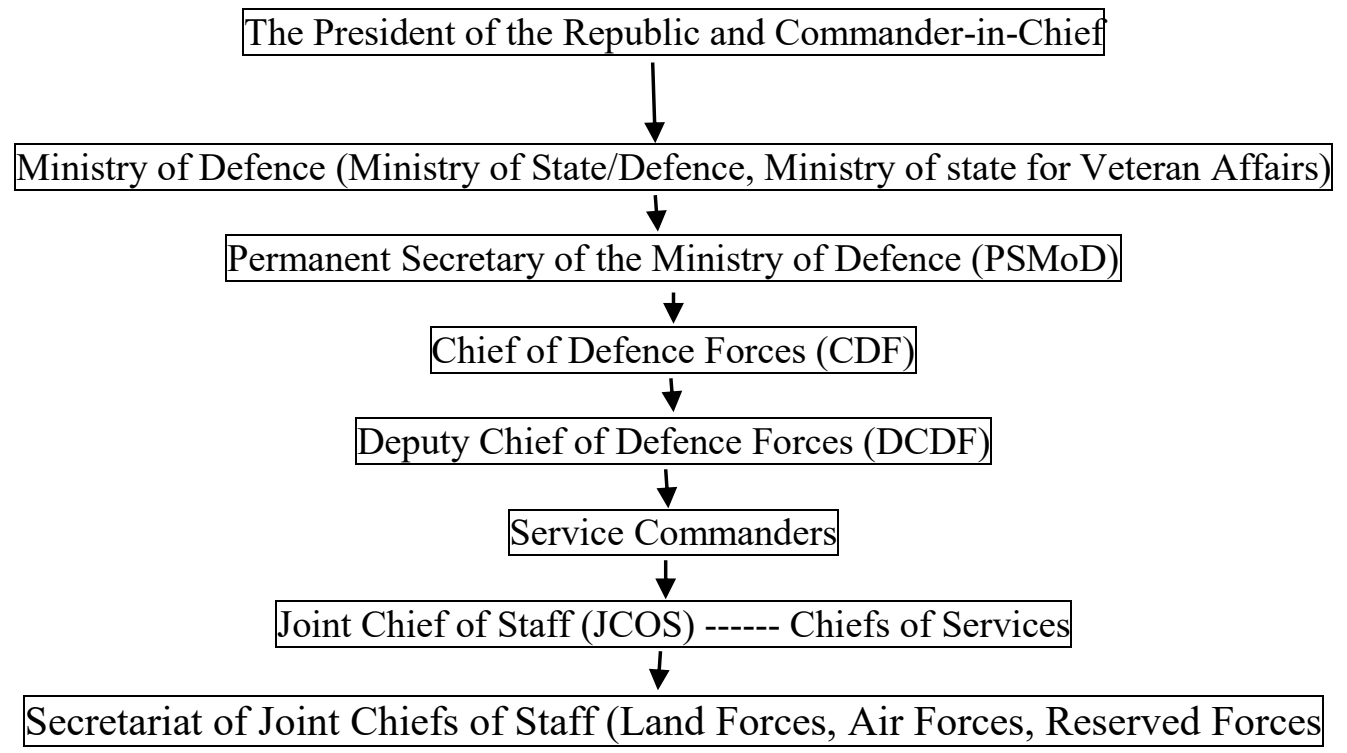

To understand the process leading to the formulation of military spending, it is necessary to also understand the nature of security threats the country faces or is likely to face in the short,

\footnotetext{
22 Uganda does not have large navy and marine forces because it is a landlocked country. Its marine forces have a very limited mission that consists of patrolling the borders along lakes Victoria and Albert that form part of Uganda's borders with the Democratic Republic of Congo, Kenya and Tanzania.
} 
medium or long term, and the role the military should play in addressing those threats. The reason for such a linkage between security threats and defence budget is that the acquisition of military capability and recruitment of manpower, which are both crucial elements of military spending, must align with the principle of adequacy ${ }^{23}$. In that regard, the policy makers in the defence sector need to address the following four questions ${ }^{24}$ :

i) What are the real threats (perceived and serious threats) that the country faces?

ii) How and when do those threats emerge?

iii) How could the army mitigate these threats?

iv) Is the military capability being procured appropriate to address the emerging threats?

The fifth question is the basis of the principle of the adequacy that requires that the government acquire the right capability that will allow the army to address the emerging security threats, but without unnecessary military purchases and recruitment. Therefore, the principle of adequacy requires that the level of defence spending provide security while minimizing any waste of scarce public resources that the government could otherwise use to fund development programs that also have a direct impact on citizens' lives.

Given the influence of the UPDF and the keen interest of the President in the defence budget, it can be difficult to apply the principle of adequacy with complete success, since there will likely be a tendency to overspend on the military. One senior military official (who requested anonymity) mentioned that Uganda's defence budget does not necessarily reflect the real needs of the defence sector. He mentioned, for example, that most often arms acquisitions for the UPDF are made without consideration of what the army really needs to defend the nation and contracts for procurements do not follow the rules of transparency set forth by the

\footnotetext{
${ }^{23}$ Interview with one Ugandan army General on $13^{\text {th }}, 2016$.

24 Ibid
} 
government and the army High Committee on arms acquisition. That respondent explained that some expenditures on such items as second-hand weapons, food, and uniforms are the result of rent seeking within the army and constitute a waste of public resources that the government could otherwise use for other programs. ${ }^{25}$

In terms of military development, what is required is the understanding of the country's posture as well as that of its potential allies and enemies. This assessment is very crucial because the military posture is a key determinant of success in overcoming national threats. Ends must be adequately linked to available means, as one UPDF commander emphasized. Since resources are scarce, it is therefore imperative that policy makers use the available means efficiently. Figure 19 below portrays the linkage between the country's strategic vision, the mission assigned to the army based on the nature of the threats and the resources that need to be mobilized for the army's performance.

Figure \# 19. Linkage between the Army's Vision and Mission ${ }^{26}$

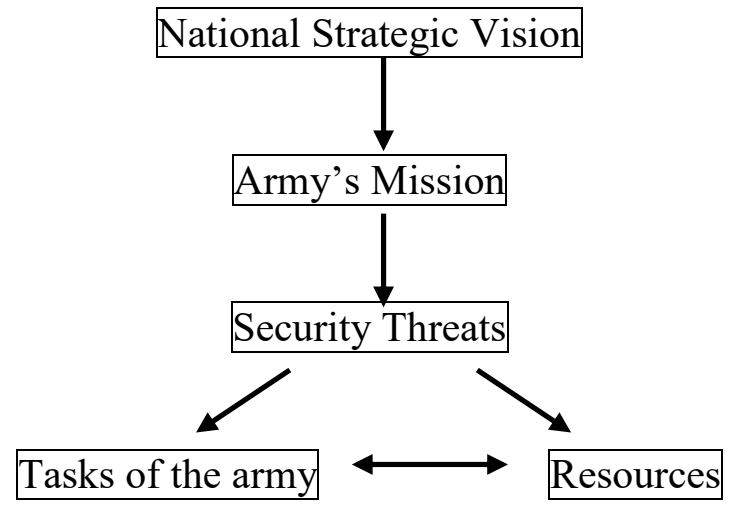

The strategic vision for Uganda's defence sector is outlined in its Defence White Paper. This is the policy document that defines the nation's interests, objectives and pathways for possible reforms of the defence sector. It also defines what kind of military procurement projects

\footnotetext{
${ }^{25}$ Interview with one UPDF commander on August $13^{\text {th }}$.
}

${ }^{26}$ Interview with one Ugandan army General on $13^{\text {th }}, 2016$ 
will be undertaken to beef up the country's military capability. However, as several interviewees emphasized, the UPDF had purchased military equipment that were not envisioned in the Defence White Paper. For instance, five respondents indicated that the purchase of 8 Sukhoi fighter jets from Russia in 2011 for a total cost of US\$ 740 million was not planned in the White Paper. ${ }^{27}$ The danger of overlooking the vision is that the policy makers in the defence sector will likely not be able to design specific tasks for the army and will not mobilize the necessary resources required for the defence budget. ${ }^{28}$

\subsection{Uganda's Security Threats}

\subsubsection{External Security Threats}

The nature of Uganda's external security threats reflects its location as a landlocked country surrounded on all sides by neighbours that are frequently exposed to significant levels of internal or external conflict. This location makes Uganda vulnerable to spillover effects from the political instability in any of its neighbours. Uganda shares borders with five other states: The Democratic Republic of the Congo (DRC) to the west, South Sudan to the north, Kenya to the east, and Rwanda and Tanzania to the south. All research participants ranked as Uganda's primary external security threats the political instability in the DRC and South Sudan and the inability of their governments to exercise effective control of their territory.

In fact, political instability, mainly as the result of civil wars in the DRC and South Sudan, adversely affects Uganda's security in many ways. It causes massive refugee flows into Uganda, thereby creating competition over natural resources between refugees and local inhabitants. Uganda hosts more than a million refugees from South Sudan, eastern DRC, Rwanda, and Burundi. That high number of refugees compounds the already existing problems

\footnotetext{
${ }^{27}$ Interviews on: July $28^{\text {th }}$ and $30^{\text {th }}$ (Café Javas); August $3^{\text {rd }}$ (Daily Monitor), August $5^{\text {th }}$ (at Protea Hotel) and August $30^{\text {th }}$ at one participant's residence.

${ }^{28}$ Comments from an interview with one Ugandan army General on August $13^{\text {th }}, 2016$.
} 
of access to such limited resources as water, food, and land in the areas where refugees settle. Uganda has a progressive refugee policy in the region, which allows refugees to have access to a plot of land to carry out agricultural activities to generate some income. Moreover, the lack of territorial control in the region gives an opportunity for armed groups potentially hostile to the Ugandan regime to exploit ungoverned spaces in order to conduct criminal activities and increase their capability to attack and destabilize Uganda. The cases of the Lord's Resistance Army (LRA) of Joseph Kony and the Allied Democratic Forces (ADF), armed groups that are both hostile to President Museveni and which have operational bases in eastern DRC and Sudan, are good illustrations of this concern.

Another senior military official (who requested anonymity) indicated that Uganda is also concerned about two other issues arising from political instability in the neighbourhood. First, there is the possibility of recruitment of armed combatants from refugee camps by foreign nonstate actors who intend to conduct military operations to destabilize the governments in their countries of origin. Monitoring such criminal activities imposes a heavy burden on Uganda in terms of resources (financial, intelligence, and materials). Second, the circulation of small and light weapons (SLWs) in the ungoverned spaces in the DRC and South Sudan makes it easier for weapons to end up in the hands of criminal groups either in Uganda or in the region, allowing them to organize violence within Ugandan territory. Therefore, the political instability in any of the neighbouring countries has adverse consequence on the regional security. For instance, when a civil war occurs, and government forces lose control of a certain portion of national territory to rebel groups, armed militias may spring up and take advantage of ungoverned spaces to conduct their criminal activities and organized violence that can destabilize another country. The civil war in Rwanda and its ensuing genocide is a good example of this regional effect, as it has 
adversely affected the security situation in eastern DRC. The current Rwandan government has alleged that the presence of former Rwandan Hutu soldiers in the DRC constitutes a threat to its own stability, thereby leading to its support of various armed Tutsi-led rebellions in eastern DRC.

With respect to the DRC, Uganda's specifics concern is the inability of the Congolese government to effectively control and police the province of North Kivu (in the eastern part of the DRC). The reason for this concern is that the ADF, a Ugandan insurgent group that has transformed into a terrorist organization, operates in the territory of Beni in North Kivu. The ADF has been active in Beni since the mid-1990s after it was pushed out of Uganda by the UPDF following several years of fighting in western Uganda. Jamil Mukul, a Ugandan citizen, created the ADF in western Uganda in the 1980s after the demise of late President Idi Amin. It was initially comprised of various groups hostile to President Museveni. The number of its combatants is estimated to be between 1,200 and 1,500. Although the ADF is out of Uganda, it has room to expand its operational capability from its bases in eastern DRC and continues to recruit in Uganda and Sudan through its sleeper cells. ${ }^{29}$ Therefore, the ADF, as a consequence of the weakness of the Congolese state, represents a major security threat to Uganda. The inability of the Congolese government to effectively control its province of North Kivu allows the ADF to conduct guerrilla operations that kill and displace innocent Congolese civilians and increase its capability to cause harm to Uganda's national security interests. It is both the weakness of the Congolese state and the presence of the ADF that are of concern for Uganda's security, consequently. The implication for Uganda's security arising from the DRC's weakness illustrates the potential for paradox in Sub-Saharan security relations. Specifically, in the absence of

\footnotetext{
${ }^{29}$ Information obtained through interviews at the Ministry of Defence's Head Quarter (Mbuya, Kampala).
} 
significant interstate conflict and rivalries, a country may be more concerned by a neighbour's weakness and inability to control its territory than by its military strength.

With respect to South Sudan, Uganda's primary concern is the potential fall of President Salva Kiir's regime into the hands of his former Vice-President Riek Machar who has ties to Sudan and its President, Omar al Bachir. If South Sudan falls under the control of a proKhartoum regime, it is very likely that armed groups such as the Lord Resistance Army and Allied Democratic Forces will establish operational bases there and expand their capability to destabilize Uganda. According to research participants, both Uganda and Sudan perceive each other as hostiles ever since South Sudan's war for secession in the late 1980s. Sudan was opposed to the independence of South Sudan and provided military support to the antisecessionist rebel movements. Also, Uganda's military intelligence services claim to have strong evidence of the Khartoum regime's military and financial support to the LRA and the ADF. Simultaneously, Sudan perceives Uganda as a hostile country because of its longstanding support for the South Sudanese independence movement. Under President Museveni, Uganda's government has provided substantial military and financial support to the Sudanese People's Liberation Army (SPLA) since the late 1980s. After South Sudan became independent in 2011, Uganda has continued to provide substantial military and financial support to the South Sudanese President Salva Kiir and its army against its domestic opposition, led by his former VicePresident Riek Machar who turned rebel.

Another external security threat Uganda faces is transnational terrorism, particularly from Al-Shabaab, the Somali Islamist group that is affiliated with al-Qaeda. According to research participants, Uganda became the target of Al-Shabaab's terrorism activities in 2007 when it first deployed troops to Mogadishu (capital of Somalia) to participate in the African Union 
Peacekeeping Mission in Somalia (AMISOM). Uganda is the largest contributor of soldiers to AMISOM. According to the interview with General Katumba Wamala, Uganda's Chief of Defence Forces, there are about 6000 Ugandan soldiers deployed to Somalia to support the AMISOM mandate. ${ }^{30}$

In retaliation for the presence of Ugandan soldiers in Mogadishu, Al-Shabaab conducted two distinct deadly bombing attacks in Kampala in July 2010, killing 86 people and injuring close to one hundred more. ${ }^{31}$ The victims were civilians who gathered in two restaurants to watch the final game of the World Cup soccer tournament between Spain and Holland in South Africa. Ever since, Uganda has been a target of Al-Shabaab. Security officials are cognizant of threats posed by this terrorist group and monitor its activities to avoid other surprise attacks in Uganda.

Additionally, because of the contiguity of borders between Kenya and Uganda and the porous nature of those borders, Uganda is vulnerable to terrorism attacks in Kenya, another state that is the target of Al-Shabaab. Kenya shares about $900 \mathrm{~km}$ of borders with Uganda (to the north). Given the porosity of the borders, the traffic of illegal weapons and terrorists increase the level of the security threat that Al-Shabaab can pose to Uganda. Numerous reports have shown that weapons and Islamist militants easily cross over into Kenya from Somalia, thereby posing a threat to not only Kenya, but to Uganda as well. ${ }^{32}$ Terrorism is a concern of the Ugandan army (as well as of other internal security services) because the army has the Constitutional mandate to defend and protect the country's sovereignty. Acting in accordance with this mandate, the UPDF have fought such terrorist groups as the Lord Resistance Army of Joseph Kony in the Northern

\footnotetext{
${ }^{30}$ Interview at the UPDF Chief of Defence Forces Office on August 22, 2016.

${ }^{31}$ See Tumusiime K., A. "Looking back at the July 11, 2010 Kampala twin bombings," The Monitor (July 11, 2013), accessed online at http://www.monitor.co.ug/artsculture/Reviews/Looking-back-at-the-July-11--2010-Kampala-twin-bombings/6912321911248-15lsxjwz/index.html.

${ }^{32}$ Information obtained from an interview with one intelligence official who claimed anonymity.
} 
Province and the Allied Democratic Forces, an Islamist group that is now operating in remote areas in eastern DRC around the Ruwenzori Mountains.

From the perspective of an inter-state conflict, I asked research participants to discuss whether they perceive any of Uganda's neighbouring states as a threat to its security. Very specifically, they were asked to rank each of Uganda's five immediate neighbours on a scale of 1 (the least threat) to 4 (the most important threat) as a potential threat. For the most part the experts that were interviewed indicated that none of the neighbouring states represents a security threat to Uganda. The majority ( 80 percent of interviewees), military and civilians alike, perceive no risk of an immediate military conflict arising from either Rwanda, South Sudan, the DRC, Kenya, or Tanzania. Almost all respondents indicated that both Kenya and Tanzania are friendly states and the least threatening states to Uganda. Tanzania has historical ties to Uganda. It provided military support to President Museveni's NRM rebellion that seized power in 1986. In addition, economic ties between Uganda and Kenya are very strong as well. Kenya is the second largest trade partner of Uganda in the region. Moreover, Uganda accesses the Indian Ocean through Kenya, representing an important trade corridor for the Ugandan economy. Furthermore, the military alliance Uganda signed with Kenya and Rwanda in 2014 precludes, or greatly diminishes the risk of, a military confrontation between the three countries ${ }^{33}$. Table 5 shows Uganda's trade (exports and imports) with its neighbours.

\footnotetext{
${ }^{33}$ Interview with General Katumba on August $13^{\text {th }}$.
} 
Table 5. Uganda's Trade with its neighbours (US\$ millions, 2000-2016)

\begin{tabular}{|c|cccccc|cccccc|}
\hline Year & \multicolumn{7}{|c|}{ Exports to: } & & \multicolumn{5}{c|}{ Imports from: } \\
& \multicolumn{1}{|c}{ Kenya } & Tanz. & DRC & Rwanda & Sudan & $\begin{array}{c}\text { South } \\
\text { Sudan }\end{array}$ & Kenya & Tanz. & DRC & Rwanda & Sudan & $\begin{array}{c}\text { South } \\
\text { Sudan }\end{array}$ \\
\hline 2000 & 55.41 & 6.53 & 7.83 & 10.00 & 6.95 & na & 216.14 & 12.16 & 0.05 & 0.43 & 0.00 & na \\
2001 & 41.55 & 7.10 & 14.74 & 12.55 & 6.95 & na & 352.38 & 8.29 & 1.34 & 1.62 & 0.00 & na \\
2002 & 60.30 & 5.52 & 9.91 & 13.12 & 4.92 & na & 332.68 & 8.36 & 1.18 & 1.79 & 0.00 & na \\
2003 & 73.04 & 5.29 & 15.27 & 20.61 & 10.16 & na & 355.91 & 12.05 & 1.92 & 0.55 & 0.00 & na \\
2004 & 66.22 & 11.49 & 27.13 & 22.77 & 18.03 & na & 390.25 & 15.53 & 2.44 & 0.68 & 0.00 & na \\
2005 & 68.85 & 7.29 & 59.61 & 31.27 & 32.09 & na & 491.68 & 10.31 & 3.10 & 0.54 & 0.00 & na \\
2006 & 66.06 & 4.26 & 44.82 & 30.52 & 89.72 & na & 346.77 & 25.68 & 0.11 & 0.43 & 0.07 & na \\
2007 & 111.87 & 0.00 & 101.28 & 83.31 & 158.20 & na & 375.92 & 22.86 & 0.10 & 1.37 & 0.15 & na \\
2008 & 159.14 & 18.94 & 129.66 & 136.95 & 249.58 & na & 461.44 & 48.21 & 1.24 & 2.86 & 0.24 & na \\
2009 & 157.43 & 32.36 & 152.01 & 136.28 & 187.84 & na & 446.46 & 38.20 & 3.13 & 3.38 & 0.61 & na \\
2010 & 187.61 & 37.61 & 182.24 & 148.89 & 202.55 & na & 473.07 & 50.11 & 6.76 & 6.65 & 3.03 & na \\
2011 & 229.33 & 42.76 & 181.49 & 193.41 & 329.20 & na & 657.30 & 39.18 & 14.89 & 7.58 & 4.31 & 0.00 \\
2012 & 254.61 & 54.92 & 238.68 & 226.15 & 403.68 & 1.92 & 608.95 & 52.89 & 30.34 & 8.00 & 4.47 & 0.00 \\
2013 & 314.11 & 48.32 & 267.93 & 216.52 & 239.11 & 174.23 & 589.01 & 46.84 & 25.86 & 7.78 & 5.87 & 0.00 \\
2014 & 341.81 & 56.12 & 182.29 & 245.37 & 101.87 & 280.55 & 608.84 & 55.43 & 29.53 & 11.84 & 4.94 & 0.00 \\
2015 & 427.33 & 62.25 & 152.05 & 237.61 & 77.83 & 265.26 & 619.25 & 78.52 & 26.80 & 11.06 & 0.42 & 2.76 \\
2016 & 422.99 & 68.09 & 177.66 & 193.98 & 48.48 & 239.25 & 512.17 & 107.04 & 75.86 & 12.39 & 0.14 & 4.92 \\
\hline
\end{tabular}

Source: Bank of Uganda (Several Years)

However, twenty percent of respondents, essentially civilians, ranked Rwanda $3^{\text {rd }}$ as a threat to Uganda. The reason is that both Rwandan and Ugandan armies clashed three times $(1999,2000 \text {, and 2002) })^{34}$ in Kisangani, a northeastern city in the DRC's Oriental province. During those military confrontations, Rwanda inflicted serious casualties on Uganda, killing hundreds of its soldiers stationed in Kisangani. In retrospective, it is worth pointing out that Rwanda and Uganda both invaded the DRC from 1998 to 2003 to provide military support to the Congolese Rally for Democracy (CRD) rebel movement. The CRD was a Tutsi-led rebellion

\footnotetext{
${ }^{34}$ Human Rights Watch (August 2002). Democratic Republic of the Congo. War Crimes in Kisangani: The Response of Rwandan-backed Rebels to the May 2002 Mutiny, Vol.14. No.6. See also The New York Times (August 16, 1999). "Rwanda and Uganda Battling To Control Key City in Congo," available at http://www.nytimes.com/1999/08/16/world/rwanda-and-ugandabattling-to-control-key-city-in-congo.html; and The Economist (August 19 ${ }^{\text {th }}$, 1999). "Rwanda and Uganda. Old Friends, new war," available at http://www.economist.com/node/233381.
} 
against the late President Laurent Kabila of the DRC, which started in August 1998 after Kabila severed ties with Rwanda and Uganda, his former allies in the war that deposed the late Mobutu Sese Seko, the dictator who ruled the DRC (the Zaire) from 1965 to 1997.

The belief that Rwanda is a potential enemy to Uganda is mostly among civilians. None of the respondents from the military mentioned Rwanda as a potential enemy. When interviewed, military officers mentioned that Rwanda and Uganda share historical ties that make the occurrence of state-to-state confrontation less likely, despite the confrontations in the DRC. In fact, President Kagame of Rwanda grew up in Uganda as a refugee, attended a military academy abroad as a Uganda citizen, and was the head of Uganda's military intelligence under President Museveni in the late 1980s and early 1990s. In addition, many of the Rwandan army's senior commanders were combatants within President Museveni's NRM. Moreover, Uganda backed the Rwandan Patriotic Front, the Rwandan rebel movement led by President Kagame that seized power in Rwanda after the genocide of 1994. However, despite such an optimistic view on Rwanda, it is noteworthy to stress that one research participant, a senior military intelligence officer, mentioned that although the risk of war between Uganda and Rwanda is very low, Rwanda's demography may constitute a serious security threat to its neighbours over the longer term, including Uganda. The logic of this reasoning is that competition over such scarce resources as land will continue to grow in Rwanda, which will likely seek alternatives outside its borders to satisfy the demand of land of its growing population. In fact, Rwanda has the highest population density in the region, estimated in 2015 to be around 470 inhabitants per square $\mathrm{km}$ (see World Bank's World Development Indicators). Figure 20 below shows the distribution of population density in the region. Uganda has the third largest population density, while the DRC has the lowest (less than 35 people per square $\mathrm{km}$ of land). Whether demography represents an 
opportunity for, or a threat to, development is a matter of how policy makers in the respective countries choose to deal with it.

Figure \# 20. Population Density in the African Great Lakes Region

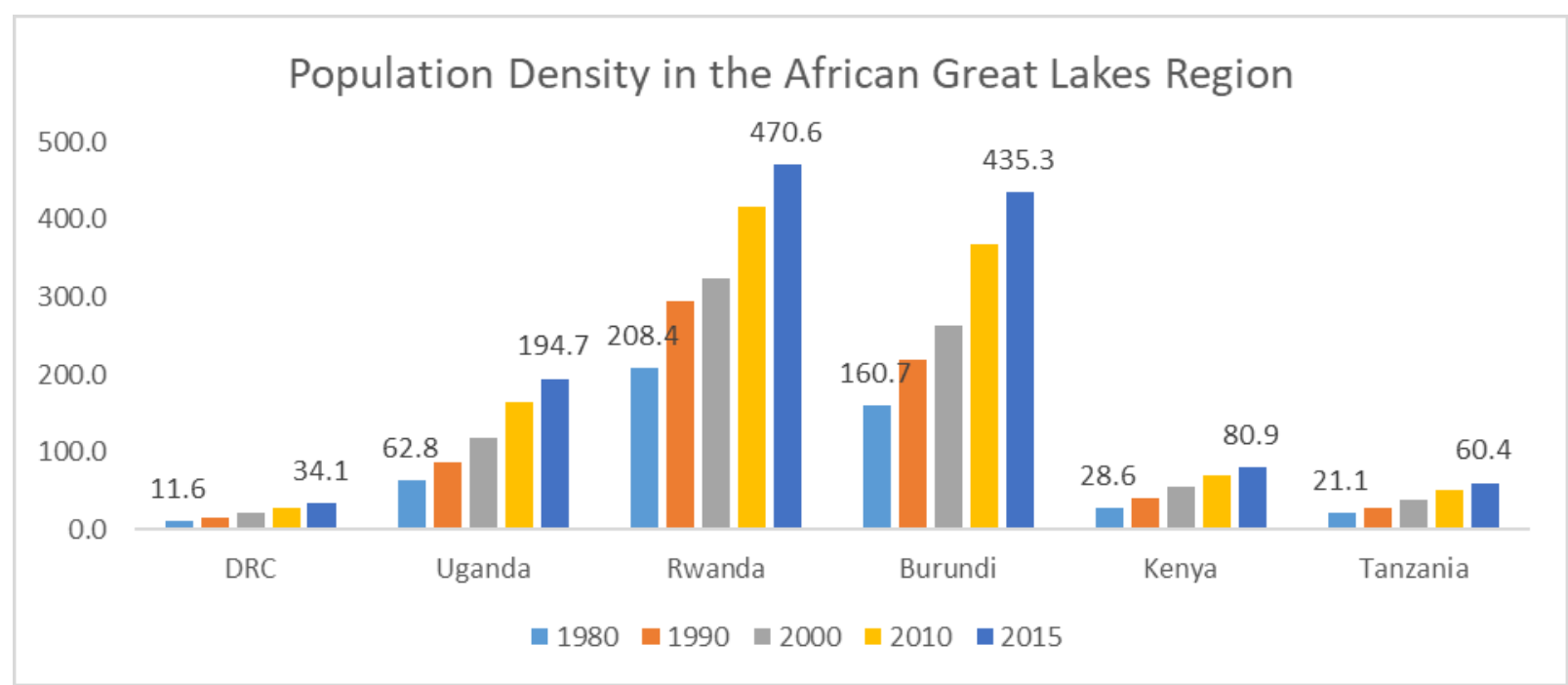

Source: World Bank, World Development Indicators

Finally, more than 60 percent of respondents identified Egypt as an external security threat to Uganda because of disagreements over the sharing of the water of the Nile River. Historically, Egypt and Great Britain signed a treaty in 1929 giving Egypt an annual water allocation of nearly 50 billion cubic meters against 4 billion cubic meters to Sudan. The treaty also granted Egypt "veto power" over any construction projects on the Nile by other riparian countries. In 1959, Egypt and Sudan signed a bilateral agreement over the use of the Nile water, raising Egypt's water allocations to 55 billion cubic meters and Sudan's allocations to 18.5 billion cubic meters. Both these agreements excluded other riparian countries for whom water is a critical resource for development (in terms of power generation and agriculture, for instance). At the time of the Anglo-Egypt treaty and Egypt-Sudan agreement, not all the other riparian countries were yet independent. ${ }^{35}$ After these countries became independent, they did not

\footnotetext{
35 There are ten permanent members to the Nile Basin Initiative, including Burundi, the Democratic Republic of Congo, Egypt, Ethiopia, Kenya, Rwanda, Sudan, South Sudan, Tanzania, and Uganda.
} 
acknowledge Egypt and Sudan's exclusive rights over the Nile water and have ever since sought to have rights equal to those of Egypt and Sudan. Several rounds of negotiation have been conducted between representatives of these countries for a political consensus. The Nile water is of critical importance to Uganda. President Museveni has launched major critical infrastructure development for power generation over the last ten years. For instance, in 2013, he launched the construction of the Karuma Hydropower Dam, which is being built on the Nile River to generate more electricity for Uganda. There are major disagreements between Egypt and Uganda over Ugandan power generation projects. Consequently, the Nile River represents a potential source of conflict in the region, including for Uganda.

\subsubsection{Uganda's Internal Security Threats}

This section discusses the different security threats that Uganda faces internally. It must be noted that because managing such threats is the primary responsibility of the police and not the army, public expenditures allocated to the police and the Internal Security Organization (the internal civilian intelligence agency in Uganda) for maintaining public order are not counted in the defence budget but are part of the broader security budget. However, given the risk that internal security threats may pose to the regime, the army can be mobilized to intervene if an uprising or other destabilizing event overwhelms the police. During the fieldwork, it was not

possible to find out how much expenditures allocated to the defence sector have been used to supplement the mandate of the police.

Interview questions related to this section asked research participants to identify and rank the most pressing internal security threats Uganda faces or may face in the short, medium, or long term. Very specifically, respondents were asked to say whether they see the potential for 
violence resulting from such issues as youth underemployment, interethnic conflict (linguistic or religious groups), or homegrown radicalization.

Most respondents indicated that the most pressing internal threat is youth unemployment. Uganda has one of the highest rates of youth unemployment in the world, estimated to be around 60 percent for the population aged between 18 and 30 years old (Uganda Bureau of Statistics, 2015). Three quarters of the population is below 30 years old and poorly educated. At least three reasons may explain Uganda's high youth unemployment: the inability of the domestic economy to create adequate employment opportunities for the youth, the inadequacy of the educational system relative to the skills required by employers, and the rapid demographic increase. Uganda's economy is very small and primarily dominated by subsistence agriculture that employs more than 85 percent of the country's labor force and accounts for more than 50 percent of GDP (Uganda Bureau of Statistics, 2016). With respect to the educational system, there is a firm belief among respondents that there is a mismatch between the skills taught to the youth at secondary and tertiary levels and the real needs of the society. Most respondents explained that the educational system does not provide students with sufficient employable skills that meet the needs of the labor market and the economy. For example, the educational system does not provide adequate training in entrepreneurial skills to allow university graduates to operate small and medium enterprises.

Youth unemployment, especially in urban areas, is a concern because political opponents of the regime can easily mobilize unemployed young Ugandans to destabilize the regime. This has already happened during recent presidential elections, for instance. Most of the supporters of Doctor Besigye, the main challenger to President Museveni, come from the youth in Uganda's major cities. One research participant indicated that President Museveni's share of vote among 
the youth in urban areas during the 2015 election was very minimal, compared to Besigye's and other candidates. The promises of employment opportunities for the youth by the opposition have been the key message of presidential campaigns. Another research participant from the military explained that the youth's access to the Internet and its many applications (WhatsApp, Facebook, etc.) represents a threat to the regime. In fact, access to the Internet facilitates communication among discontented groups and increases their ability to mobilize against the regime and conduct mass protests. The implication of youth unemployment on the military budget is the recruitment of the youth in paramilitary units. One research participant explained that there is a special fund in the defence budget for such a program ${ }^{36}$. That respondent indicated that the regime is cognizant of the dangers unemployed Ugandans may pose to the regime; but due to limited financial resources, there are not many options that the government has at its disposal to address the problem. Uganda is a small economy dependent on agriculture and with a very small private sector that cannot absorb a significant share of the unemployed youth.

With respect to the potential for ethnic conflict, 65 percent of respondents ranked it as the second internal security threat that Uganda faces. This finding shows that ethnic discrimination is still a major issue in Uganda, especially in the army (at strategic positions that support the regime, such as military intelligence, presidential guards, and logistics), public administration, and employment opportunities. Respondents who support the claim that ethnicity is still an obstacle to equality in Uganda said that one ethnic group, namely the Bahima sub-group from the Banyakore group from western Uganda, has more political and military power than any other group. The Banyakore, the group to which the president belongs, controls all strategic positions within Uganda's security sector (army, police, and internal and external security organizations) and public administration. Speaking on ethnicity, one respondent indicated during an interview

\footnotetext{
${ }^{36}$ Interview with one UPDF General on August 13 $3^{\text {th }}, 2016$.
} 
that only 1 out 6 army generals comes from groups other than the Banyakole ${ }^{37}$. Other researchers corroborate respondents' claims that ethnicity is still a major issue in Uganda's military politics. Omara-Otunnu (1987) provides ample evidence that ethnic factors have always been central in Uganda's politics and civil-military relations during pre-colonial time and after independence. Kagoro (2015) sees President Museveni, his NRM and the army as effectively indistinguishable. Lindemann (2011) reveals that the Banyakole hold more than 40 percent of the 23 UPDF's top command posts and about 30 percent of the top five army ranks. Heiberg (2010) studies the civilmilitary relations in Uganda and concludes that the Banyakole dominate the ethnic composition of the army by occupying strategic positions within the security apparatus.

It is worth mentioning that more than 73 percent of those interviewed for this research (22 participants) cited the President's longevity in office as a security threat to Uganda's stability. President Museveni has been in office since January 1986 following a five-year guerilla war (1981-1986) his National Resistance Army waged against Milton Obote and Tito Okelo's regimes. After ascending to power in Kampala, Museveni banned political parties and established a no-party democratic system tightly controlled by his NRM (see Carbone, 2008 and Tripp, 2010). Multiparty resumed in Uganda in 1996 and ever since, Museveni has won all the elections, changing the constitution to his advantage with the support of members of parliament from his NRM; and there is no sign whatsoever of him leaving soon (see Tangri and Mwenda, 2010).Some respondents pointed out that the President's monopoly of power has created a democratic deficit and uncertainty over how any power transition would unfold in the event of the President's death or incapacitation. Eight participants indicated that there is no consensus over the succession of President Museveni within the NRM.

\footnotetext{
37 The Banyakole form Uganda's second largest ethnic group representing 9.6 percent of population after the Baganda group, which represents 16.5 percent of population (see Uganda, CIA/The World Factbook, at https://www.cia.gov/library/publications/the-world-factbook/geos/ug.html
} 
His hold on power has even created disenchantment within the military. One third of research participants explained that Museveni lost the vote in all the military barracks during the 2015 elections. The respondents explained that some members of the army no longer support the regime and would consider a regime change. They elaborated that the fear of the regime being overthrown by some units of the army was so high during the 2015 election that the President recruited Congolese soldiers ${ }^{38}$ as mercenaries to ensure security in such towns as Busheni, Kanungu, and Ntungamu ${ }^{39}$ in western Uganda and other major strategic sites, such as the army's airfield in Kampala. Many respondents indicated that the lack of trust in the regular army motivated the President to create a Special Brigade Forces that is totally controlled by his son, Major-General Muhoozi Kainerugaba. This unit is well funded, trained, and equipped relative to other army's units and is mostly composed of more than 12,000 soldiers from the Banyakole ethnic group (see also Kagoro, 2013c). There is a general belief among respondents that the true motivation for creating that unit is specifically to protect the President and the regime against potential coups. Other respondents mentioned that the President's son is being prepared to take over power, should something fatal happen to his father. One interviewee mentioned that the logic behind Museveni's thinking is as follows: "If I collapse, we all collapse together." This line of reasoning implies that the elites within the Banyakole ethnic group and associates are concerned about losing power and are cognizant of the need for a collective response and protection in order to keep it. ${ }^{40}$

The implications of this political uncertainty on the defence budget are twofold: there is unequal funding and treatment of the army's units, and control of the army resources by the

\footnotetext{
38 The respondents based their claim on the fact that those soldiers were speaking French, a language not spoken in Uganda or any other neighbouring states, except in the DRC and Rwanda. However, President Museveni's allies in Rwanda are primarily English speaking, and it would be unlikely that the government would have brought in Francophone Rwandans.

${ }^{39}$ Ntungamu is President Museveni's hometown.

${ }^{40}$ I use collective as an adjective to refer to the dominant ethnic group, i.e the group that controls power in Uganda, which is believed to be the Banyakole.
} 
elites contributes to corruption and rent-seeking behavior within the army, particularly with regard to military procurements. The question of differential treatment of army units is well known in Uganda and could lead to larger defence budgets (in order to better fund some units) as well as a misallocation of resources leading to a less effective military. For instance, several interviewees asserted that the Presidential Guards Brigade (PGB) and the Special Forces Command (SFC) are better funded, trained, and equipped compared to other units of the UPDF and are not under direct authority of the Chief of Defence Forces, but rather is overseen by officers with family ties to the President. This preferential treatment of some units of the army is a major source of frustration among soldiers. One interviewee highlighted that the reason why most UPDF soldiers did not vote for Museveni in 2016 was that they feel neglected.

Corruption in the military is also a serious problem because it increases the size of the defence budget (see Gupta, de Mello, and Sharan, 2000). With respect to elite corruption in the army, Tangrir and Mwenda (2013) document various cases of corruption and embezzlement of the defence budget in the 1990s by senior army commanders with family ties to President Museveni and his wife, First Lady Janet Museveni. They document how several senior defence officials, civilian and military, have enriched themselves through illegal purchases of obsolete military war materials and by awarding contracts to themselves and their associates without competition. For instance, these authors show how Major General Salim Saleh, Museveni's younger brother, had used UPDF resources for self-enrichment. In 1996, while commander of the counter-insurgency operations fighting the Lord Resistance Army (LRA), General Saleh awarded his aviation company a monthly tender of USD 400,000 to supply commodities to UDPF soldiers in the north. On another occasion, Tangri and Mwenda (2013) argue that Saleh personally convinced President Museveni to bypass legal procedures of the MoD to grant a 
lucrative contract to an associated British company called Consolidated Sales Corporation (hereafter CSC) to supply four Mi-24 attack helicopters to the UPDF. The four helicopters delivered to Uganda turned out to be useless, but cost USD 12 million, while their true cost was estimated to be USD 7 million. Saleh received about a million dollars' commission for facilitating the purchase of the MI-24 helicopter gunships. Tangri and Mwenda (2013) also document that it was customary for several UDPF commanders to illegally award themselves contracts of supplying foods, ammunitions, and other commodities to UPDF soldiers engaged in war zones, whether in Uganda or in regional conflicts, at overblown charges. Another scheme of corruption documented by Tangri and Mwenda (2013) is the listing of ghost soldiers on the military payroll, thereby inflating the size of the army. According to these authors, Several UPDF commanders close to Museveni had kept for many years the names of deceased soldiers on the army payroll to enrich themselves. It is estimated that between the 1990s and up to 2003, the number of ghost soldiers in the UPDF was around 15,000 (see Tangri and Mwenda, 2013: 69-89).

\subsection{Conclusion}

This chapter discusses three important issues related to Uganda's defence budget. It first analyses the process leading to the formulation of the military budget, the actors who have the final decision in that process, and the structure of the defence budget. The analysis from the fieldwork shows that in principle Uganda's military budget is embedded in the process of the national budget, thereby demonstrating that Uganda's military is treated as a normal and integral part of the government and society. However, the analysis also shows that the President of the Republic, to a larger degree through his ruling party, exercises significant power over the military budget including having the final decision on its level. The analysis also shows that 
there is a lack of transparency in the defence budget caused by classified expenditures. The exact amount of these expenditures as well as their use are not revealed to the public, except to the Auditor General of the Republic. The power the President has over the defence budget and the classified expenditures impede the ability of the Parliament to discharge effectively its mandate to provide budget oversight and checks and balances within the system. The implications of this problem are twofold: an increased likelihood of corruption and rent seeking within the military, and the weakening of political and economic institutions that are in charge of not just defence and security, but also other critical social and political projects such as national development.

Second, the data show that the defence budget, while increasing in level, has grown somewhat more slowly than other key components of the national budget, such as expenditures on education, public infrastructure, and health. Overall, defence spending has fallen from over $17 \%$ of the national budget in $1994 / 5$ to around $8 \%$ in $2015 / 16$. The evolution of the defence budget, therefore, suggests that it has not dominated other areas of spending that are more immediately associated with social and economic development.

Third, the analysis identifies the different external and internal threats Uganda faces, which in turn could be expected to the level of defence spending and the process by which it is approved. The external security threats Uganda faces are twofold. First, political instability in both the DRC and South Sudan, and, second, transnational terrorism from Al-Shabaab in Somalia. Political instability in the DRC and South Sudan is the generally perceived as the primary source of Uganda's external security threat for several reasons. Instability in its neighbours has resulted in refugees' inflows into Uganda, the presence of armed groups hostile to the Ugandan regime, such as the Allied Democratic Forces and the LRA in ungoverned spaces in eastern DRC, and the circulation of small and light weapons that may end up in the hands of 
organized criminal groups that can threaten the regime. From an interstate conflict perspective, however, the research shows that none of the states neighbouring Uganda is perceived as an immediate threat because the risk of a military confrontation is minimal. Internally, the most pressing security threats Uganda faces are threefold, namely youth unemployment, potential ethnic conflict, and the longevity of the President's tenure in office and the ensuing uncertainty over power transition should he die. Most research participants cited these three problems as threats to Uganda's security and development, though their effect on the level of the defence budget is unlikely to be dramatic, since the UPDF does not have primary responsibility for internal security. Instead, it is secondary linkages through problems such as favoritism and corruption in the military that may connect internal security concerns with defence spending.

To conclude, defence spending in Uganda generally follows a process of intragovernmental bargaining and political oversight over public expenditures. Despite the government's military roots, and the President's ultimate control over military spending, the defence budget has not overwhelmed other government priorities. In addition, the nature and level of internal and external threats to Uganda do not seem to be posing a serious challenge to its security. While there are several perceived threats that may influence Uganda's defence budget, the limited volatility of military spending over time suggests that overall there is a perception that Uganda's government has been able to provide a reasonable level of security without compromising its obligations to promote social and economic development as well. 


\section{References}

Abdelfattah M., Y.et al. (2014). "The Demand for Military Spending in Egypt," Defence and Peace Economics," 25:3, 231-245.

Carbone, G. (2008). No-Party Democracy? Uganda Politics in Comparative Perspective (Boulder, Co: Lynne Rienner Publishers).

Decalo, S. (1990). Coups and Army Rule in Africa. Motivations and Constraints. (London: Yale University Press).

Denzin N., K. (ed) (2011). The SAGE Handbook of Qualitative Research. (Los Angeles: Sage).

Dowdle, A. (1992). “A Cross-National Model of Military Spending in African Nations," Journal of Political and Military Sociology 20 (2), pp. 153-169.

Dunne, P. and Perlo-Freeman, S. (2003a). "The Demand for Military Spending in Developing Countries," International Review of Applied Economics (January), Volume 17, Issue 1

Dunne, P. and Perlo-Freeman, S. (2003b). "The Demand for Military Spending in Developing Countries: A Dynamics Panel Analysis," Defence and Peace Economics (December), Volume 14 , Issue 6.

Dunne, P., Perlo-Freeman, S. and Smith, Ron P. (2003). "The Demand for Military Spending in Developing Countries: Hostility versus Capability," Defence and Peace Economics (August), Volume 19, Issue 4

Fredrickson, P. and Looney, R. (1986). Defense Expenditures in Developing Countries: Some Further Empirical Evidence (Monterey, CA: U.S. Naval Postgraduate School).

Gupta, S., de Mello, L. and Sharan, R. "Corruption and Military Spending," in Abed T., G. and Gupta, S. (eds) (2002). Governance, Corruption, Economic Performance. International Monetary Fund (Washington, D.C).

Hennink M., M. (2011). Qualitative Research Methods. (Los Angeles: Sage)

Human Rights Watch. (1999). Hostile to Democracy: The Movement System and Political Repression in Uganda. (New York: Human Rights Watch).

Kagoro, J. (2013a). "The Military Ethos in the Politics of Post-1986 Uganda," Social Sciences Directory, Vol. 2. No.2, pp.31- 46.

Kagoro, J. (2015b). Militarization in Post-1986 Uganda. Politics, Military and Society Interpretation. LIT Verlag. 
Kagoro, J. (2013c). "Security Counterweights: A Power-Maximizing Sociopolitical Strategy in Uganda," Africa Peace and Conflict Journal, Vol. 5 (1), 1-13.

Kaguri, S. (1996). Roots of Instability in Uganda. (Kampala: Fountain Publishers).

Kobusingye, O. (2010). The Correct Line? Uganda under Museveni. (Central Milton Keynes: AuthorHouse).

Lindemann, S. (2011). "Just another Change of Guard? Broad-Based Politics and Civil War in Museveni's Uganda," African Affairs, Vol. 110 (440), 387 - 416.

Lindemann, S. (2011). "The Ethnic Politics of Coup Avoidance: Evidence from Zambia and Uganda," Africa Spectrum, Vol. 46, No. 2, pp. 3-41.

Looney L., R. "Internal and External Factors in Effecting Third World Military Expenditures," Journal of Peace Research 23, no. 3 (1989): 329-338.

MacDonald, B. (1997). Military Spending in Developing Countries (Ottawa, ON: Carleton University Press).

Karungi, Mafumbo C. (2011). Interventionist Foreign Policy: Uganda's Security Challenges: A Study (LAP LAMBERT Academic Publishing).

Mugisha, A. (2004). “Museveni’s Machinations," Journal of Democracy, Vol. 15 (2), pp.140144.

Mwenda M., A. (2007). "Personalized Power in Uganda," Journal of Democracy, Vol. 18 (3), pp. 23-37.

Omitoogun, W. (2003). Military Expenditure Data in Africa: A Survey of Cameroon, Ethiopia, Ghana, Kenya, Nigeria and Uganda, SIPRI Research Report No. 17 (Oxford: Oxford University Press).

Omara-Otuunu, A. (1987). Politics and the Military in Uganda, 1890 - 1985 (Basingstoke, Oxford: McMillan)

Omara-Otuunu, A. (1998). "The Currency of Militarism in Uganda," in Hutchful, Eboe and Bathily Abdoulaye (eds): The Military and Militarism in Africa (Dakar: CODESRIA).

Otunnu, O. (2017). Crisis of Legitimacy and Political Violence in Uganda, 1890 to 1979. Springer International Publishing (ebook).

Prunier, G. (2004). "Rebel Movements and Proxy Warfare: Uganda, Sudan, and the Congo (1986-99)," African Affairs, Vol. 103 (412), 359-383. 
Prunier, G. (2009). From Genocide to Continental War: the 'Congolese' Conflict and the crisis of contemporary Africa (London, UK: Hurst and Co).

Ravenhill F., J. (1974). "Military Rule in Uganda: The Politics of Survival," African Studies Review, Vol. 17 (1), pp. 229-260.

Reno, W. (2002). "Uganda's politics of war and debt relief," Review of International Political Economy, Vol. 9, No. 3, pp. 415-435.

Rubongoya, J. (2007). Regime Hegemony in Museveni's Uganda. Pax Musevenica. (New York: Palgrave MacMillan).

Ritchie, J. and Ormston, R. (2003). "The Application of Qualitative Methods to Social Research," in Ritchie, J. et al. (eds). Qualitative Research Practice. A Guide for Social Science Students and Researchers. (London: Sage). Chapter 2.

Tangri, R. and Mwenda, A. (2003). Military Corruption and Uganda Politics since Late 1990s," Review of African Political Economy, Vol. 30 (98), pp. 539-552.

-----------. (2010). "President Museveni and the Politics of Presidential Tenure in Uganda," Journal of Contemporary African Studies, Vol. 28 (1), pp. 31-49.

--------------. (2013). The Politics of Elite Corruption in Africa. Uganda in Comparative African Perspective (New York: Routledge).

Tripp M., A. (2004). "The Changing Face of Authoritarianism in Africa: The Case of Uganda," Africa Today, Vol 50 (3), pp. 3-26. (2010). Museveni’s Uganda. (Boulder, Co.: Lynne Rienner)

Twaddle, M. and Holger Bernt Hansen (1998). "The Changing State of Uganda," in Holger B., H. and Twaddle, M. (eds). Developing Uganda (Athens, Ohio: Ohio University Press).

United Nations, The causes of conflict and the promotion of durable peace and sustainable development in Africa, Report of the Secretary-General, UN document A/52/871-S/1998/318, 13 Apr. 1998, p. 7, URL <http://www.securitycouncilreport.org/atf/cf/\%7B65BFCF9B-6D274E9C-8CD3-CF6E4FF96FF9\%7D/Arms\%20S\%201998\%20318.pdf

Word Bank: World Development Indicators database 


\section{Chapter 2. The Demand for Defence Spending in Uganda: A Time-Series Analysis}

\subsection{Introduction}

The purpose of this chapter is to investigate the factors that influence the level of military expenditures $^{41}$ in Uganda, with a focus on the period of President Yoweri Kaguta Museveni's reign. Uganda's military spending under President Museveni grew from US \$ 172 million in 1986 to US\$ 398 million in 2016, an increase of 131 percent. During this period under observation Uganda spent on average US\$ 257 million (constant 2015 US dollars) on defence. This average hides some interesting variations, however. Figure 21 below exhibits significant fluctuations in the trajectory rather than a steady increase. There appears to be three different phases in Uganda's defence spending under Museveni. The purpose of this chapter is to investigate the source of defence budget variation between and within these phases, with a particular emphasis on the effect of internal and external security threats.

The first phase (1986-1992) exhibited a reduction of 43 percent, from US\$ 172 million to US\$ 98 million. This decline in spending occurred despite a dramatic increase in the number of Uganda's military personnel from around 20,000 in 1986 to 70,000 in 1992 (World Bank's Development Indicators). The increase in personnel occurred in large part because of the need to integrate the defeated soldiers of Milton Obote and members of other armed groups into a single unified army as part of a policy of national reconciliation after President Museveni took power in 1986.

The second phase is a sustained upward trend between 1993 and 2009. During this period, Uganda's defence spending increased steadily by 200 percent over about 16 years. The increase in spending, rising from US\$ 100 million to US\$ 300 million, reflected a growing role

\footnotetext{
${ }^{41}$ Research participants agreed that the definition of military expenditures in Uganda is consistent with SIPRI's definition.
} 
for Uganda's armed forces in regional conflicts as participant and peacekeeper, as well as its own internal civil conflicts.

Figure 21. Trend of Uganda's Military Expenditure, 1973-2016 (in million, constant 2015 US\$)

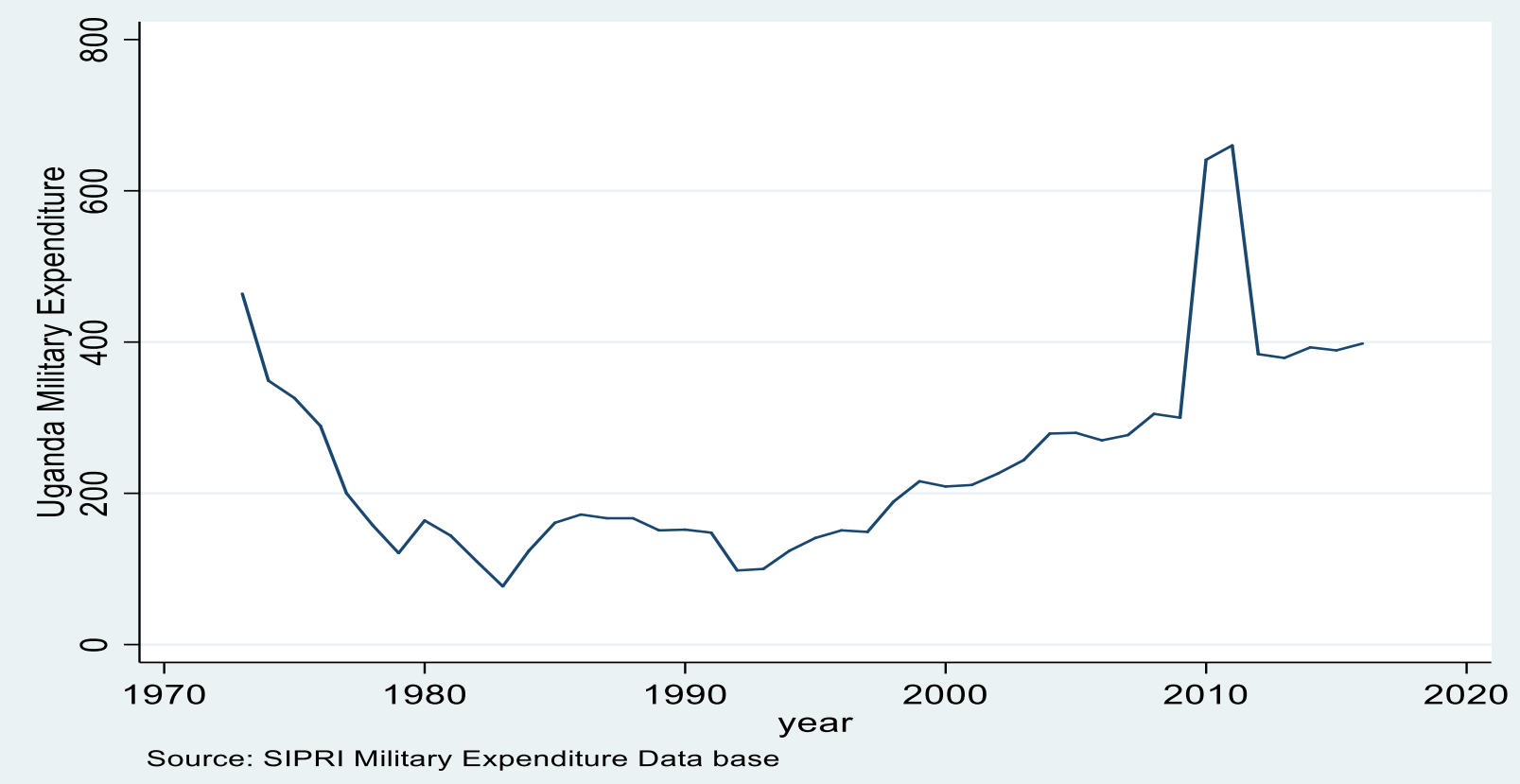

The third and final phase (2009-2016) is in part a continuation of the steady increase from 1993-2009, but it begins with a spike in expenditures in 2010-2011. This spike is caused primarily by the purchase of eight fighter Sukhoi jets from Russia. Research participants I interviewed during the fieldwork in Kampala in July and August 2016 identified two factors that may justify such a purchase. First, the prospect of additional revenues from the exploitation of oil discovered in the Lake Albert gave the President an impetus to modernize the Ugandan air force. According to interviewees, President Museveni instructed the Central Bank of Uganda to pay for the fighter jets using the Bank's reserve funds, anticipating that the government will use future oil revenues to cover the spending. Second, some interviewees identified the purchase of the Sukhoi as a deterrence to discourage any attack from Egypt caused by disagreements over 
water use from the Nile River, a critical resource for Uganda as well as downstream riparian states. Since Uganda's strategic depth is very small, and since Egypt has an overwhelmingly larger military, Uganda's government saw more advanced fighter jets as a critical strategic asset to deter any incursions which (in the absence of a land border) would likely have to come by air. While the increased spending for the jets was short-lived, Uganda's military expenditure had increased in real terms from around \$US 300 million in 2009 to about \$US 400 million.

Uganda's history of civil wars (see Lindemann, 2011), its military engagement in regional conflicts, and the availability of consistent time-series data on defence spending make it an interesting case for the study of the demand for military spending in Sub-Saharan Africa. Dunne and Perlo-Freeman (2003b) remark that studying individual countries is the best way of understanding changes in military expenditures across time because such expenditures respond differently to changes in variables across-countries and across time. Before proceeding, a caveat is worth emphasizing. Although there are data available for Uganda's defence spending since 1962 to date, the focus of this study is on Uganda under the regime of President Museveni's. Two reasons justify this choice. First, before President Museveni, Uganda lacked political stability as it experienced an unstable internal political environment marked by military coups and prolonged civil wars. This instability prevented Uganda from having a coherent national defence strategy that could justify a consistent strategy for the determination of the level of military spending. Second, understanding the motivations behind the demand for military spending under one regime may provide some interesting insights as to how the regime defines its security environment and the factors that it considers when determining the size of its military budget. 
The remainder of this chapter is organized as follows. The next section describes the hypotheses examined in the empirical analysis. Section 3 defines and summarizes the variables used in the model and identifies the data sources. Section 4 presents the empirical analysis, including the econometric features of the data and the description of the dynamic model, while section 5 discusses the empirical results. Section 6 provides the conclusions of the chapter.

\subsection{Hypotheses}

The quantitative methodology in this chapter complements the qualitative methodology in the previous chapter. Interviews, along with the findings of similar studies in other countries, inform the selection of explanatory variables and associated hypotheses, and the findings of the statistical analysis will be compared with responses collected from the fieldwork.

The first two hypotheses are derived from interviews conducted in Uganda ${ }^{42}$. The first of these deals with the external threat environment faced by Uganda. I follow Perlo-Freeman and Dunne (2008) in constructing a "security web" variable, which in this study is the sum of military expenditures of six immediate neighbours ("Security Web 1") because those countries form Uganda's security web. Rosh (1988) defines a nation's security web as neighbours and other countries that can affect its security. A second version ("Security Web") includes Egypt's defence spending as well. The security web variable accounts for regional strategic factors that can affect Uganda's security. Empirical studies by Rosh (1988), Dunne and Perlo-Freeman (2003a and 2003b), Collier and Hoeffler (2004), Dunne, Perlo-Freeman, and Smith (2008), show that the military spending of a nation's neighbours positively and significantly influences its own defence spending. Interview responses from the fieldwork support the incorporation of the security web variable in the analysis. As already explained, research participants explained that

\footnotetext{
${ }^{42}$ Although there appears to be a consensus from all research participants as to what the security threats Uganda faces are, participants from the military minimized the internal threats, while civilian respondents considered them as serious.
} 
security dynamic at the sub-regional level influences Uganda's level of security (see details in the chapter from the fieldwork). I use the same approach here as the base case, and thus define hypothesis 1 as the following:

Hypothesis 1: If the sum of the defence spending in neighbouring states increases, then Uganda's defence spending will increase as well.

There are a number of factors that may modify this hypothesis, however, and these are also explored here. First, interviews indicated that Uganda does not regard all of its neighbours as equal threats. Indeed, in some cases military spending in some countries (allies and countries whose military weakness can encourage civil conflict that can spill over into Uganda) may actually reduce the pressure on Uganda's military. In addition, the standard security web analysis that looks at total military spending in neighbouring states does not really reflect threat potential. For example, a very weak country that increases its defence budget may not really be seen as a challenge to a much more powerful state, and hence the latter need not react. Finally, the standard security web analysis may not apply as clearly to the African context, since interstate conflict is extremely rare due in part to the tacit understanding between Africa states that the colonial boundaries, however problematic, are not to be revised through military conflict. In my analysis, I therefore supplement the security web analysis with an examination of each neighbour's military spending separately. While not all the countries can be examined due to the relatively small sample, looking at individual states facilitates an examination of some of the details of the region's security dynamics.

The second hypothesis derived from the interviews deals with internal threats. Uganda's long history of civil conflict suggests that the military has a potentially important role in securing 
the government against internal armed opposition. Consequently, I identify the following hypothesis:

Hypothesis 2: If there is extensive internal civil conflict against organized armed groups, then Uganda's defence spending will increase ${ }^{43}$.

Interviews suggest that some care is needed in terms of formulating expectations about hypothesis 2. First, interviews indicated that the defence budget is not as responsive to civil conflict because the primary burden of countering domestic violence lies with other security agencies in Uganda, not the military per se. While the military provides a back stop in terms of securing the government, it may not be responsive to lower levels of civil conflict.

Finally, previous studies of military spending identify potentially important factors that can affect defence spending. The first of these factors is the capacity of the country's economy to support military spending. The importance of resource availability is reflected in hypothesis 3 :

Hypothesis 3: If GDP increases, then military spending will also increase.

The connection between GDP and the defence budget may not be immediate or stable. Defence spending reflects other pressures and security considerations rather than simply being a mechanical or automatic claim on the country's economic capacity. The size of the economy is a permissive factor that determines the ease with which defence spending increases can be accommodated. Past studies, however, and political economy arguments about budget processes, both suggest that defence spending will tend to increase fairly proportionately with GDP, and that military spending as a proportion of GDP will tend to be reasonably stable over the medium

\footnotetext{
${ }^{43}$ The civil war variable I use to operationalize this hypothesis is a dummy variable identifying years in which Uganda was experiencing internal conflict and is based on the interview responses and the Correlates of War database. I tried to use other potential variables such as the number of casualties at the battle field from the Correlates of War project, but consistent data were not available for several years in the period under examination.
} 
to longer term despite the fact that the budget process typically focuses on absolute spending levels, not spending as a share of GDP.

The last hypothesis reflects one of the important dilemmas about developing country budgeting: to what extent do security concerns deflect resources from spending on development? This dilemma is not just a concern for the governments of poorer countries that are trying to balance their responsibilities to protect their citizens and to improve their material well-being. The wealthier countries that provide development assistance may also be concerned with the extent to which their financial support ends up financing government activities (such as defence spending) that is not the original objective of the aid.

Hypothesis 4: As official development assistance (ODA) receipts increase, defence spending will also increase.

Hypothesis 4 reflects the potential fungibility of development assistance. If the relationship between ODA and defence spending is indeed positive, then it suggests that the recipient government can use the aid inflows as a substitute for their own resources and reallocate their own resources to other spending priorities. It is also possible that the relationship could be negative, which may reflect the influence of donors in influencing or constraining the spending decisions of recipient governments. Foreign assistance often comes with conditions attached that restrict the extent to which recipient governments can determine spending, and restricting defence spending is a popular target for donors. Of course, it is also the case that ODA inflows may be unrelated to defence spending in any stable manner, which may reflect either a balancing of fungibility and conditionality, or simply that the two are simply independent. 


\subsection{Variables' Description and Sources of Data}

Table 6 (below) provides a description of the variables and the sources of the data used in the analysis. The dependent variable is the level of military expenditures because defence policy makers who participated in the interviews during the fieldwork emphasized that they do not consider the share of defence expenditures to GDP (hence military burden) in the process of the military budget. For this chapter, the focus of the analysis is the period of 1986 to 2016 . The purpose of focusing on this time-period is to understand the determinants of military spending in Uganda under the dispensation of President Museveni who has been in power since January 1986. The main independent variables are defined in table 6, though it should be noted that in some of the robustness analysis slightly modified versions of these variables are used as well. It is also important to note that in operationalizing the model, the log of the continuous variables is used to capture non-linearities in the relationships and to transform the estimating coefficients into elasticities. 
Table 6. Variable Descriptions and Source of Data

\begin{tabular}{|c|c|c|}
\hline Variables & Descriptions & Source \\
\hline Uganda Milex & $\begin{array}{l}\text { Uganda's military expenditures (dependent } \\
\text { variable, in millions, constant } 2015 \text { USD) }\end{array}$ & $\begin{array}{l}\text { SIPRI Military } \\
\text { Expenditures database }\end{array}$ \\
\hline DRC Milex & $\begin{array}{l}\text { DR Congo's military expenditures (in millions, } \\
\text { constant } 2015 \text { USD) }\end{array}$ & SIPRI \\
\hline Rwanda Milex & $\begin{array}{l}\text { Rwanda's military expenditures (in millions, } \\
\text { constant } 2015 \text { USD) }\end{array}$ & SIPRI \\
\hline Kenya Milex & $\begin{array}{l}\begin{array}{l}\text { Kenya's military expenditures } \\
\text { constant 2015 USD) }\end{array} \\
\end{array}$ & SIPRI \\
\hline Tanzania Milex & $\begin{array}{l}\text { Tanzania's military expenditures (in millions, } \\
\text { constant } 2015 \text { USD) }\end{array}$ & SIPRI \\
\hline Sudan Milex & $\begin{array}{l}\text { Sudan's military expenditures (in millions, } \\
\text { constant } 2015 \text { USD) }\end{array}$ & SIPRI \\
\hline South Sudan Milex & $\begin{array}{l}\text { South Sudan's military expenditures (in millions, } \\
\text { constant } 2015 \text { USD) }\end{array}$ & SIPRI \\
\hline Security Web 1 & $\begin{array}{l}\text { The sum of military expenditures of Uganda's } \\
\text { neighbours (in millions, constant } 2015 \text { USD) }\end{array}$ & Compiled from SIPRI \\
\hline Security Web & $\begin{array}{l}\text { Security Web } 1 \text { plus Egypt's military expenditures } \\
\text { (in millions, constant } 2015 \text { USD) }\end{array}$ & Compiled from SIPRI \\
\hline Civil War & $\begin{array}{l}\text { A binary variable indicating the presence of } \\
\text { significant civil conflict in Uganda. }\end{array}$ & Fieldwork \\
\hline Real GDP & $\begin{array}{l}\text { Uganda's real GDP (at constant national prices, in } \\
\text { millions, constant } 2011 \text { US\$) }\end{array}$ & World Bank \\
\hline Net ODA & $\begin{array}{l}\text { Net development assistance received by Uganda } \\
\text { (in millions, constant } 2010 \text { USD) }\end{array}$ & World Bank \\
\hline
\end{tabular}

Table 7 below provides the summary statistics for the main variables used in the analysis.

As noted above, there are other variables that are tested for robustness of the results, but these are not reported here. Among the other variables tested are population, per capita GDP, and alternative forms of the civil war variable. Table 7 presents the characteristics of the raw data, not the log-transformed data used in the model estimation. 
Table 7. Descriptive Statistics of Variables

\begin{tabular}{lrrrrr}
\hline Variable & Obs & Mean & Std.Dev. & Min & Max \\
\hline Uganda Milex & 44 & 242.205 & 132.696 & 77 & 660 \\
DRC Milex & 44 & 137.614 & 119.759 & 21 & 503 \\
Rwanda Milex & 44 & 69.932 & 28.836 & 31 & 152 \\
Kenya Milex & 44 & 752.955 & 247.811 & 374 & 1370 \\
Tanzania Milex & 44 & 254.659 & 123.773 & 105 & 643 \\
Sudan Milex & 44 & 1673.955 & 1153.152 & 314 & 4923 \\
S.Sudan Milex & 11 & 1221.455 & 312.432 & 525 & 1730 \\
Egypt Milex & 44 & 5312.955 & 1288.171 & 3572 & 8055 \\
Security Web 1 & 44 & 3194.477 & 1764.732 & 1134 & 7662 \\
Security Web & 44 & 8507.25 & 2178.054 & 4955 & 12868 \\
Civil War & 44 & .636 & .487 & 0 & 1 \\
Real GDP & 44 & 29286.39 & 21760.18 & 9674.3 & 79906.8 \\
Net ODA & 44 & $8.84 \mathrm{e}+08$ & $5.49 \mathrm{e}+08$ & $5.50 \mathrm{e}+07$ & $1.80 \mathrm{e}+09$
\end{tabular}

\section{4. Empirical Analysis}

In this section, I present the key statistical tests that help to determine the estimation procedure. The data represents a time series of military expenditures and associated variables, implying that problems of correct inference can arise from the non-stationarity of the data. In addition, I test for the degree of cointegration. These tests are described below.

\subsubsection{Tests for Unit Root and Lag Order Selection}

Because the data in the estimated model are a time-series, econometric rules require that I first conduct the tests of stationarity of the variables (see Hill, Griffiths, and Lim, 2011; Becketti, 2013; Gujarati, 2006; Dougherty, 2011). The reason is that regressions of non-stationary timeseries can yield spurious estimates. To determine whether the series are stationary or not, I conducted the Augmented Dickey-Fuller (ADF) test for unit root. For this end, I had to determine the lag length of each variable. The results of this test are presented in Table 8 and indicate that all the series are non-stationary in their levels. 
With respect to the determination of the lag length, there was a discrepancy between the lag length suggested by the Akaike Information Criterion (AIC), the Final Predictor Error (FPE), the Hannan-Quinn Information Criterion (HQIC), and the Schwarz-Bayesian Information Criterion (SBIC) for the variables in models estimated in tables 10 and 11. For the variables in models 1 to 4 in Table 2.5, the AIC and FPE indicated 4 lags, while the HQIC and the SBIC indicated one lag. For the variables in models in Table 2.6 (models 5 to 10), only the SBIC indicated one lag, while the three other criteria indicated 4 lags. I therefore let the program (Stata $15^{\text {th }}$ edition) determine the lag length using the appropriate commands when running the regressions.

Table 8. Results of the Augmented Dickey Fuller Test for Unit Root

\begin{tabular}{|l|l|l|l|l|}
\hline \multirow{2}{*}{ Variable } & \multicolumn{2}{l}{ Level } & \multicolumn{2}{l|}{ First Difference } \\
\cline { 2 - 5 } & T-Statistic & P-value & T-Statistic & P-Value \\
\hline Log Uganda Milex & -1.671 & 0.4461 & -5.326 & $0.0000^{* *}$ \\
\hline Log DRC Milex & -1.963 & 0.3031 & -4.750 & $0.0001^{* *}$ \\
\hline Log Rwanda Milex & -2.050 & 0.2650 & -5.385 & $0.0000^{* *}$ \\
\hline Log Kenya Milex & -2.122 & 0.2356 & -3.540 & $0.0070^{* *}$ \\
\hline Log Tanzania Milex & -0.863 & 0.9931 & -3.173 & $0.0216^{*}$ \\
\hline Log Sudan Milex & -1.569 & 0.4989 & -4.755 & $0.0001^{* *}$ \\
\hline Log South Sudan Milex & -1.476 & 0.5456 & -3.713 & $0.0039^{* *}$ \\
\hline Log Egypt Milex & -1.493 & 0.5368 & -4.095 & $0.0010^{* *}$ \\
\hline Log Security Web & -1.161 & 0.6903 & -3.656 & $0.0048^{* *}$ \\
\hline Log Security Web & -1.043 & 0.7374 & -3.100 & $0.0266^{*}$ \\
\hline Log Real GDP & 2.885 & 1.000 & -3.274 & $0.0161^{*}$ \\
\hline LogNetODA & -1.641 & 0.4619 & -9.304 & $0.0000^{* *}$ \\
\hline
\end{tabular}

The reported $p$-value is the MacKinnon Approximate. Significant at $5 \%$ level $(*)$ and $1 \%$ level (**).

All of the variables are stationary in their first differences, however, which means that they are integrated of order one, I (1). I chose the ADF test instead of the normal Dickey-Fuller test to account for serial correlation of the variables.

\subsubsection{Test of Co-Integration}

Because the series are stationary in their first differences, I performed the Johansen Test of co-integration to account for the dynamic relationship between the variables. For this purpose, I had first to determine the optimal number of lags for each model to take into consideration in 
the analysis. I reject the null hypothesis of no co-integration based on the Trace and maximum Eigen Value statistics from the Johansen test and establish the presence of one co-integrating equation for both models 1 and 4 but two co-integrating equations for models 2 and 3. Table 9 below summarizes the results of the Johansen test.

Table 9. Summary of the Johansen Test of Co-integration

\begin{tabular}{|l|l|l|l|l|}
\hline Models & Max. Rank & Eigenvalue & Trace Statistic & Critical value (5 \%) \\
\hline 1 & 1 & 0.66720 & $21.6232^{*}$ & 29.68 \\
\hline 2 & 2 & 0.65708 & $10.6897 *$ & 15.41 \\
\hline 3 & 2 & 0.43301 & $12.8054^{*}$ & 15.41 \\
\hline 4 & 1 & 0.53979 & $26.7549^{*}$ & 29.68 \\
\hline
\end{tabular}

The presence of co-integrating equations lends credence to the hypothesis of the presence of a long-run relationship between the independent variable and its regressors.

\subsection{Model Specification}

Given that the variables are I (1), I estimate the error-correction model parameterizing the long-run coefficient using the autoregressive distributed lag model, which captures the dynamic relationship between the dependent variable and the explanatory variables. The general form of the ARDL model that I use in this study is of the following form ${ }^{44}$ :

\footnotetext{
44 Various versions of the general model were attempted. For example, I tried including the population variable in the regressions, but the coefficient was not statistically significant, implying that the population variable does not influence Uganda's defence budget. In general, the results reported below are consistent with those from these alternative estimations, while the inclusion of other variables such as GDP per capita did not identify other variables with statistically significant coefficient estimates.
} 


$$
\begin{aligned}
\text { Milex }_{\mathrm{t}}=\beta_{0}+ & \sum_{\mathrm{i}=1}^{\mathrm{m}} \beta_{\mathrm{i}} \Delta \text { Milex }_{\mathrm{t}-1}+\sum_{\mathrm{i}=0}^{\mathrm{m}} \alpha_{\mathrm{i}} \Delta \mathrm{SW}_{\mathrm{t}-\mathrm{i}}+\sum_{\mathrm{i}=0}^{\mathrm{m}} \gamma_{\mathrm{i}} \Delta \text { REALGDP }_{\mathrm{t}-\mathrm{i}}+\sum_{\mathrm{i}=0}^{\mathrm{m}} \delta_{\mathrm{i}} \Delta \text { SNetODA }_{\mathrm{t}-\mathrm{i}} \\
& +\lambda_{0} \text { Milex }_{\mathrm{t}-1}+\lambda_{1} \text { SW }_{\mathrm{t}-1}+\lambda_{2} \text { REALGDP }_{\mathrm{t}-1}+\lambda_{3} \text { NetODA }_{\mathrm{t}-1}+\lambda_{4} \mathrm{CW}_{\mathrm{t}}+\varepsilon_{\mathrm{t}}
\end{aligned}
$$

Where: Milex $x_{t}$ is the military expenditure (in logarithm), SW is the security web (in log), REALGDP is real Gross Domestic Product (in log), Net ODA is net official development assistance received (in $\log$ ) and $\mathrm{CW}$ is the dummy civil war variable. The terms $\beta, \alpha, \gamma$, and $\lambda$ are the coefficient estimates (elasticities) for each of the explanatory variables, the subscripts $t$ and $t$ 1 refer to the current and past time period t, and $\varepsilon$ is the error term.

The Auto-Regressive Distributed Lag Model (ARDL) is suitable for this analysis for many reasons. It takes into consideration the dynamic effects from the lagged explanatory variables and the lagged of the dependent variable. In addition, since the model includes sufficient number of lags of both the dependent and explanatory variables, it permits to eliminate the problem of serial correlation in the errors. Moreover, the model has policy implication as it enables to capture the multiplier effects of explanatory variables on Uganda's military expenditures (in the long run), which is the policy variable for this analysis.

\subsection{Empirical Results ${ }^{45}$}

The results of the ARDL estimations are presented in Tables 10 and 11 below. In Table 10, models 1 and 3 relates to the period of 1973 to 2016 (the full sample for which data are available), while models 2 and 4 examine the demand for military spending in Uganda under President Museveni (from 1986 onward). The purpose of separating those two periods is to distinguish how the coefficient estimates of the independent variables differ between the

\footnotetext{
${ }^{45}$ It is important to emphasize here that the focus of the interpretation of the relationship for all variables is over the long-run, not over the short-term. This is so because of the cointegrating relationship between the variables (see Pesaran, Shin, and Smith, 2001 for a technical discussion on the existence of a long-run/cointegrating relationship in ARDL models)
} 
Museveni period and earlier years. In model 1 and 2, the security web variable (denoted Security Web 1) relates to the sum of the defence spending of Uganda's immediate neighbours (the DR Congo, Kenya, Rwanda, Sudan, South Sudan, and Tanzania), while the security web variable in models 3 and 4 (Security Web) includes the defence expenditure of Egypt.

The estimation results reported in Table 10 demonstrate that the coefficient of the speed of adjustment for each model is negative, statistically significant and less than 1 in magnitude, indicating thereby that there is a long-run relationship between the dependent variable (Uganda's defence spending) and the explanatory variables. The coefficient of adjustment in model 1 and model 2 shows that, respectively, 68 percent and 79 percent of Uganda's defence spending reverts to equilibrium over a one-year period, while the coefficient in model 3 and 4 shows that nearly 70 percent and 74 percent of such spending revert to equilibrium over a one-year period. These speeds of adjustment are consistent with the general literature on defence spending and ARDL models in general, where the expectation is that the coefficient will be negative, between -1 and 0 , and statistically significant. In terms of this one important criterion, the model performs well.

In terms of hypothesis 1 , the coefficient estimates for the security web variable (lagged) are positive and statistically significant in all four models. As an elasticity, it indicates that, overall, a one percentage increase in the past year defence spending of neighbouring countries is associated with an increase in Uganda's defence spending of between 0.307 percent (model 1) and 0.70 percent (model 4). This response is higher when the security web includes Egypt's defence spending and is also higher under the Museveni regime. Therefore, I am unable to reject hypothesis 1 and conclude that security dynamics in the region directly influence Uganda's defence spending, albeit with an elasticity of response that is less than one. 
With respect to hypothesis 2 , the result is somehow not encouraging as the coefficient of the civil war variable is unexpectedly negative but statistically significant only for model 4 and not significant at all in the other three models. The expectation was that the coefficient would be positive and statistically significant under President Museveni's period because of the long civil war the Ugandan army had fight in the North against the Lord Resistance Army (LRA) between 1988 and 2007. Based on this result, I am unable to draw a persuasive conclusion regarding the effect of civil war on Uganda's defence budget.

Hypothesis 3 reflects the standard presumption that a state's resource capacity is positively related to defence spending. The hypothesis is supported by the results presented in the table. The coefficient of lagged real GDP, which is the elasticity of Uganda's defence spending to real GDP, is positive and statistically significant in all the four models, demonstrating that an increase in the size of the economy a year ago results in an increase in the next year defence budget. Specifically, the coefficient of real GDP indicates that a one percentage increase in Uganda's real GDP translates into, respectively, 0.60 percent (model 1), 1.583 percent (model 2); 0.50 percent (model 3); and 1.20 percent (model 4) increase in next year's defence spending ${ }^{46}$. It is useful to note that the elasticity of defence spending to real GDP is about double under President Museveni (models 2 and 4) relative to the period including the pre-Museveni regime. Overall, during Museveni’s government, defence spending as a proportion of GDP would have tended to increase conditional on other factors being held constant.

\footnotetext{
${ }^{46}$ Based on the elasticity of Uganda's defence spending under President Museveni period, one can conclude that defence spending is treated as a luxury good.
} 
Table 10. Estimation Results

\begin{tabular}{|c|c|c|c|c|}
\hline & Model (1) & Model (2) & Model (3) & Model (4) \\
\hline $\begin{array}{l}\text { ADJUSTMENT } \\
\text { Lagged Log Military } \\
\text { Expenditure }\end{array}$ & $\begin{array}{c}-0.680^{* * *} \\
(-5.83) \\
\end{array}$ & $\begin{array}{l}-0.794^{* * *} \\
(-4.80) \\
\end{array}$ & $\begin{array}{c}-0.698^{* * *} \\
(-6.88) \\
\end{array}$ & $\begin{array}{l}-0.741^{* * *} \\
(-5.10) \\
\end{array}$ \\
\hline $\begin{array}{l}\text { Long-Run Relationship } \\
\text { Lagged log real gdp }\end{array}$ & $\begin{array}{l}0.606^{* * *} \\
(4.14)\end{array}$ & $\begin{array}{c}1.583^{* * *} \\
(6.27)\end{array}$ & $\begin{array}{l}0.501^{* * *} \\
(3.81)\end{array}$ & $\begin{array}{l}1.204^{* * *} \\
(4.65)\end{array}$ \\
\hline $\begin{array}{l}\text { Lagged log security web } 1 \\
\text { (Without Egypt) }\end{array}$ & $\begin{array}{c}0.307^{* *} \\
(3.01)\end{array}$ & $\begin{array}{l}0.366^{* *} \\
(3.66)\end{array}$ & & \\
\hline Lagged log net ODA & $\begin{array}{l}-0.185 \\
(-1.66)\end{array}$ & $\begin{array}{c}-2.200^{* * *} \\
(-5.11)\end{array}$ & $\begin{array}{c}-0.0464 \\
(-0.46)\end{array}$ & $\begin{array}{c}-1.917^{* * *} \\
(-4.60)\end{array}$ \\
\hline Lagged civil war & $\begin{array}{l}0.210 \\
(1.28)\end{array}$ & $\begin{array}{c}-0.0694 \\
(-0.54)\end{array}$ & $\begin{array}{l}0.106 \\
(0.79)\end{array}$ & $\begin{array}{l}-0.398^{*} \\
(-3.09)\end{array}$ \\
\hline $\begin{array}{l}\text { Lagged log security web } \\
\text { (Including Egypt) }\end{array}$ & & & $\begin{array}{c}0.590^{* * *} \\
(4.30)\end{array}$ & $\begin{array}{c}0.701^{* *} \\
(4.23) \\
\end{array}$ \\
\hline $\begin{array}{l}\text { Short-Run Relationship } \\
\text { D.log real gdp }\end{array}$ & $\begin{array}{l}0.412^{* *} \\
(3.41)\end{array}$ & $\begin{array}{l}6.050^{* *} \\
(4.09)\end{array}$ & $\begin{array}{l}0.350^{* *} \\
(3.24)\end{array}$ & $\begin{array}{l}5.576^{* *} \\
(3.97)\end{array}$ \\
\hline LD.log real gdp & & $\begin{array}{l}-0.649 \\
(-0.59)\end{array}$ & & $\begin{array}{l}0.453 \\
(0.42)\end{array}$ \\
\hline L2D.log real gdp & & $\begin{array}{l}3.598^{* *} \\
(3.29)\end{array}$ & & $\begin{array}{c}3.628^{* *} \\
(3.56)\end{array}$ \\
\hline L3D.log real gdp & & $\begin{array}{l}2.834^{*} \\
(3.03)\end{array}$ & & $\begin{array}{l}2.707^{*} \\
(2.98)\end{array}$ \\
\hline D.log security web 1 & $\begin{array}{l}0.208^{* *} \\
(2.79)\end{array}$ & $\begin{array}{l}0.262^{*} \\
(2.96)\end{array}$ & & \\
\hline LD. $\log$ security web 1 & & $\begin{array}{l}-0.148 \\
(-1.63)\end{array}$ & & \\
\hline D.log net ODA & $\begin{array}{l}-0.125 \\
(-1.59)\end{array}$ & $\begin{array}{c}-0.657^{* *} \\
(-3.52)\end{array}$ & $\begin{array}{c}-0.0324 \\
(-0.46)\end{array}$ & $\begin{array}{l}-0.543^{* *} \\
(-3.53)\end{array}$ \\
\hline LD.log net ODA & & $\begin{array}{l}0.672^{* *} \\
(4.55)\end{array}$ & & $\begin{array}{l}0.566^{* *} \\
(3.91)\end{array}$ \\
\hline L2D.log net ODA & & $\begin{array}{l}0.413^{*} \\
(2.67)\end{array}$ & & $\begin{array}{l}0.309 \\
(2.15)\end{array}$ \\
\hline L3D.log net ODA & & $\begin{array}{l}0.385^{*} \\
(2.68)\end{array}$ & & $\begin{array}{l}0.309^{*} \\
(2.25)\end{array}$ \\
\hline D.civil war & $\begin{array}{l}0.246 \\
(1.98)\end{array}$ & $\begin{array}{l}0.274^{*} \\
(2.41)\end{array}$ & $\begin{array}{l}0.234^{*} \\
(2.16)\end{array}$ & $\begin{array}{l}0.195 \\
(1.97)\end{array}$ \\
\hline LD.civil war & $\begin{array}{l}0.0275 \\
(0.25)\end{array}$ & $\begin{array}{l}0.239 \\
(1.75)\end{array}$ & $\begin{array}{l}0.0464 \\
(0.47)\end{array}$ & $\begin{array}{l}0.360^{*} \\
(2.45)\end{array}$ \\
\hline L2D.civil war & $-0.485^{* * *}$ & $-0.439^{* *}$ & $-0.485^{* * *}$ & $-0.386^{*}$ \\
\hline
\end{tabular}




\begin{tabular}{lcccc} 
Constant & 0.255 & $24.62^{* * *}$ & $-2.924^{*}$ & $19.12^{* * *}$ \\
& $(0.32)$ & $(5.42)$ & $(-2.60)$ & $(5.54)$ \\
\hline $\mathrm{N}$ & 40 & 31 & 40 & 31 \\
$\mathrm{R}-$ Squared & 0.732 & 0.963 & 0.789 & 0.962 \\
\hline
\end{tabular}

$t$ statistics in parentheses

${ }^{*} p<0.05,{ }^{* *} p<0.01,{ }^{* * *} p<0.001$

Finally, the results in Table 10 shows that the coefficient of the lagged net official development assistance received variable is also statistically significant under the Museveni period, but is unexpectedly negative. The interpretation is that in the long run, a one percentage increase in development assistance results into a decrease of 2.2 percent (model 2) and 1.91 percent (model 4) of defence spending. This result suggests that, in the long run, development aid does not appear to leak into military spending. It is difficult to know what accounts for this negative relationship. It could be that the country has become more stable under Museveni, simultaneously reducing the need for military spending while attracting more ODA. It is also possible that policy conditionality exerted by bilateral donors and multilateral institutions such as the World Bank - all of which became more heavily engaged in Uganda after Museveni took power - have successfully discouraged the shift of resources to the military.

The results reported in table 10 are encouraging. Not only are the coefficient estimates plausible, but also the goodness of fit measures (with $\mathrm{R}^{2}$ values between 0.73 and 0.96 ) suggest that the models are performing reasonably well. The high value of R-Squared under Museveni may indicate a consistency in the defence policy, in contrast to the pre-Museveni period. I also 
performed the bound test and its result confirms the existence of the long-run relationship between the variables.

To better comprehend the effect of security interdependence between Uganda and countries within its security web, I take the analysis one step further by examining the effect of individual neighbour's defence expenditure on Uganda's. Table 11 below gives the results of these estimations. The objective is to test whether Uganda's defence budget reacts differently to any specific neighbour when examined individually. In addition to examining each neighbour's defence spending individually, the spending of the other states in the security web are also examined by taking the security web variable used previously and subtracting from it the spending of the neighbour being examined. This analysis allows for a more formal test of some of the results reported in chapter one. In that chapter, the analysis shows that some key informants identified some specific neighbours as potential enemies while others are considered friendly states. Potential enemies include specifically Rwanda and Sudan for reasons explained in detail in chapter one. It is thus important to assess the impact of each of these two countries' defence expenditure on Uganda's.

The results in Table 11 provide important insights regarding the effects of the military expenditures of Uganda's individual neighbours on its own spending. The models in table 11 examine the long-run impact of the defence spending of, respectively, the DRC, Rwanda, Kenya, Tanzania, Sudan, and Egypt ${ }^{47}$ on Uganda's defence budget. Very specifically, the estimations results show that the coefficient of the error correction parameter (speed of adjustment) is negative and statistically significant in all five models. Additionally, the coefficient of the lagged

\footnotetext{
${ }^{47}$ I exclude South Sudan in this part of the analysis because of a lack of data for the defence expenditures for South Sudan; data are available only from 2006 and there are insufficient years to run the model. It can be noted, however, that South Sudan does not really seem to represent a military threat to Uganda. The interviews from the fieldwork indicated that not only did Uganda support the independence of South Sudan but remains the main purveyor of security to the regime of President Salva Kiir.
} 
real GDP is also positive and statistically significant in all the five models. These results are consistent with the estimations in models 1 to 4 examined earlier.

In terms of performance, the models again appear to be reasonable. The coefficient for the speed of adjustment are all negative, statistically significant, and less than one in magnitude. The only exception is model 7 that examines Kenya, in which the estimated adjustment coefficient is very slightly more than one in magnitude. The elasticity of Uganda's military spending to its GDP are all statistically significant though they exhibit some variation between the different models (the range is from 0.394 to 0.727 ). This variation suggests that although Uganda's income elasticity of defence spending is positive and less than one - supporting hypotheses 3 - the estimate lacks precision. It should be noted that hypothesis 4 regarding ODA inflows could not be tested in these models as the models have too few observations to run with any additional variables. The low number of observations also explain why individual neighbour spending could not all be run separately in one model. The R2 values for the different models are all reasonable, ranging from 0.43 to 0.77 . 
Table 11. Empirical results for models using individual country defence spending

\begin{tabular}{|c|c|c|c|c|c|c|}
\hline $\begin{array}{l}\text { Model } \\
\text { Country of focus }\end{array}$ & $\begin{array}{l}5 \\
\text { DRC }\end{array}$ & $\begin{array}{l}6 \\
\text { Rwanda }\end{array}$ & $\begin{array}{l}7 \\
\text { Kenya }\end{array}$ & $\begin{array}{l}8 \\
\text { Tanzania }\end{array}$ & $\begin{array}{l}9 \\
\text { Sudan }\end{array}$ & $\begin{array}{l}10 \\
\text { Egypt }\end{array}$ \\
\hline $\begin{array}{l}\text { Lagged log military spending } \\
\text { in Uganda }\end{array}$ & $\begin{array}{l}-0.600 * * * \\
(-4.80)\end{array}$ & $\begin{array}{l}-0.774 * * * \\
(-5.87)\end{array}$ & $\begin{array}{l}-1.024 * * * \\
(-6.68)\end{array}$ & $\begin{array}{l}-0.916 * * * \\
(-5.98)\end{array}$ & $\begin{array}{l}-0.596 * * * \\
(-4.72)\end{array}$ & $\begin{array}{l}-0.828 * * * \\
(-7.06)\end{array}$ \\
\hline \multicolumn{7}{|c|}{ Long-term relationships (all variables are the log of the value lagged one year) } \\
\hline Real GDP & $\begin{array}{l}0.548 * * * \\
(4.00)\end{array}$ & $\begin{array}{l}0.724 * * * \\
(7.36)\end{array}$ & $\begin{array}{l}0.450 * * * \\
(8.22)\end{array}$ & $\begin{array}{l}0.394 * * * \\
(7.26)\end{array}$ & $\begin{array}{l}0.515^{* * * *} \\
(4.87)\end{array}$ & $\begin{array}{l}0.727 * * * \\
(6.29)\end{array}$ \\
\hline Security web ${ }^{a}$ & $\begin{array}{l}0.474^{*} \\
(2.39)\end{array}$ & $\begin{array}{l}0.166 \\
(0.84)\end{array}$ & $\begin{array}{l}0.798 * * * \\
(3.95)\end{array}$ & $\begin{array}{l}0.823 * * * \\
(4.00)\end{array}$ & $\begin{array}{l}0.416 \\
(1.40)\end{array}$ & $\begin{array}{l}-0.135 \\
(-0.34)\end{array}$ \\
\hline DRC military spending & $\begin{array}{l}0.458^{*} \\
(2.10)\end{array}$ & - & - & - & - & - \\
\hline Rwanda military spending & - & $\begin{array}{l}-0.280 \\
(-0.82)\end{array}$ & - & - & - & - \\
\hline Kenya military spending & - & - & $\begin{array}{l}0.366^{* *} \\
(3.42)\end{array}$ & - & - & - \\
\hline Tanzania military spending & - & - & - & $\begin{array}{l}0.611 * * * \\
(5.22)\end{array}$ & - & - \\
\hline Sudan military spending & - & - & - & - & $\begin{array}{l}0.457^{*} \\
(2.22)\end{array}$ & - \\
\hline Egypt military spending & - & - & - & - & - & $\begin{array}{l}0.653 * * \\
(3.30)\end{array}$ \\
\hline Number of observations & 40 & 40 & 40 & 40 & 40 & 40 \\
\hline $\mathrm{R}^{2}$ & 0.430 & 0.543 & 0.766 & 0.612 & 0.431 & 0.700 \\
\hline
\end{tabular}

$t$ statistics in parentheses, ${ }^{*} p<0.05,{ }^{* *} p<0.01,{ }^{* * *} p<0.001$
a: the security web variable is the regular security web variable less the defence spending of the neighbour examined in each specific model.

Focusing on the effects of military spending by neighbouring states, the overall security web variable (i.e. the sum of all neighbours' military spending less that of the country of focus in each model) has mixed results. Three of the coefficient estimates (models 5.7 and 8) are positive and statistically significant, while the other three (models 4,6 and 10) yield statistically 
insignificant coefficient estimates. These results suggest that any assertion of a strong and consistent security web effect may not be warranted, though clearly there is evidence of some response on Uganda's part.

The overall security web effect also needs to be interpreted in light of the effects of the defence spending of individual neighbours. With respect to the long-run effect of military expenditure of the DRC on Uganda's (model 5), the estimations show that the coefficient of the DRC's military expenditure is not only positive, but also statistically significant. It shows that, in the long-run, a one percentage increase of past year of the Congo's defence expenditure results in 0.46 percent increase in Uganda's defence budget. While this result shows a positive correlation between the defence expenditure of the two countries, the interviews from the fieldwork did not indicate the possibility of a military threat from the DRC as a state. During the fieldwork, it emerged that the Congo poses a threat to Uganda only because of the inability of its government to control its eastern regions of North Kivu, leaving room for the Allied Democratic Forces (ADF, a Ugandan rebel group) to operate. Future research may shed light on this complex case.

Surprisingly, the coefficient of the lagged of Rwanda's military expenditure in model 6 is not statistically significant. This is an unexpected result given that interviews from the fieldwork portrayed Rwanda as a potential source of security threat for reasons explained in chapter 1 . As with the DRC, however, Rwanda's relationship with Uganda is complex. Initially the Rwandan regime of President Paul Kagame was closely allied with President Museveni's Uganda. Kagame once served with Museveni's army before leading the Rwandan Patriotic Front to military victory in Rwanda. This alliance, which may be reflected in the negative coefficient estimate for Rwanda's defence spending, later became strained and ultimately severed as Rwanda and Uganda found themselves backing opposing factions in the civil war in the DRC. Therefore, the 
absence of a strong statistical association between the defence spending of the two countries may reflect the volatility of the relationship rather than the absence of any connection.

The estimations in model 7 show a positive and statistically significant coefficient of Kenya's military spending. A one-percentage increase of defence spending in Kenya, in the long run, results in almost 0.4 percent increase in Uganda's defence budget. Again, during the fieldwork, research participant mentioned that Kenya as a state does not represent a security threat to Uganda as it is a friendly state. Moreover, it is important to mention that, given that Uganda's army (estimated at 55 thousand people) is larger than Kenya's (20 thousand), Uganda should not be concerned about increase of Kenya's defence spending. The observed result is consistent with standard arms race models in other contexts. It may also be the case that Kenya's military spending and Uganda's are responding to a common factor not captured in the model: a possible candidate might be expenditures related to the conflict and instability in Somalia, which borders Kenya and has also led to deployment of Ugandan forces as an intervention force.

The estimations of model 8 indicate that Uganda's defence spending also changes directly with Tanzania's. The estimated elasticity indicates that, in the long-run, a onepercentage increase in one lag Tanzania's military expenditures results in 0.6 percent increase in the current year of Uganda's defence expenditure. This result is even more puzzling that the one found for Kenya, since key informants reported in Chapter 1 also indicated that Tanzania does not represent a threat to Uganda. Moreover, Tanzania's army of estimated 28,400 active military personnel (World Bank's development indicators) is less than Uganda's army of 55,000 active military personnel. Because of this balance of power, Uganda should be less concerned about increase in Tanzania's defence spending. Compared to the case of Kenya, it is even harder to 
identify possible security threats shared by Tanzania and Uganda that are not accounted for in the model.

The results in model 9 show the elasticity of Uganda's defence spending to Sudan's military expenditure. The coefficient of the elasticity is also positive and statistically significant. Over the long run, a one percent increase in the defence spending of Sudan is associated with a 0.46 percent increase in Uganda's defence spending. This result is consistent with the findings of the fieldwork (chapter one). During the interviews, the majority of research participants mentioned that Sudan is a security threat (a hostile state) to Uganda because of the security dynamics related to South Sudan and the mutual distrust between Kampala and Khartoum resulting from support each regime provided to their respective rebel groups. One senior Ugandan military officer explained that there is an arms competition between Sudan and Uganda as a result of the traditional hostility between them, and despite the fact that the creation of South Sudan meant that Sudan and Uganda no longer shared an immediate land border. Given the absence of a shared land border since the independence of South Sudan in 2011, it is important to note that the risk of direct military confrontation between the countries has decreased relative to the pre-2011 level. Any military confrontation between the two countries is even more likely to be restricted to the use of proxies fighting in South Sudan.

Finally, model 10 shows the elasticity of Uganda's defence spending to Egypt's. The coefficient of the elasticity is positive and statistically significant, indicating that Uganda's defence spending is directly associated with Egypt's defence spending. A one percentage increase in Egypt's military expenditures is associated with an increase of 0.65 percent in Uganda's defence budget over the long-term, exhibiting the highest response elasticity of any of the individual countries examined in the analysis. Two points are noteworthy here. First, as some 
research participants explained during the interviews for chapter one, although Uganda and Egypt are miles away from each other and do not share common land borders, the lack of agreement over the management of the water of the Nile River has been a potential source of conflict between the two countries. Second, despite the physical distance between the two countries, Egypt's military power is significantly higher than Uganda's capability, causing Uganda to be concerned about Egypt's military standing, particularly because of the disagreement over the Nile water. As explained in chapter one, Uganda's purchase of the Sukhoi jets in 2011 from Russian was for deterrence purpose vis-à-vis Egypt firepower, given the shallow strategic depth Uganda has. Despite the absence of a shared border, Egypt's superior strategic capabilities may well appear to Uganda as a serious threat.

Based on the above results, the relative magnitudes of the coefficient estimates for each individual country's defence spending suggest that Uganda is more sensitive to the defence spending of (in decreasing order) Egypt, Tanzania, the DRC, Sudan, Kenya and Rwanda. While some of these results are consistent with the responses provided during the interviews, the strong association of defence spending with countries such as Tanzania are unexpected.

\subsection{Conclusion}

The purpose of this chapter was to examine the most important factors that influence the demand for military spending in Uganda, using the auto-regressive distributed lag model (ARDL). This model is suitable for this analysis because of the dynamic relationship between the variables. The results of the test of stationarity showed that the variables of interests are all integrated of order one (I (1)). The coefficient of the error correction parameter confirmed the presence of a long run causality from the independent variables to the dependent variable. 
The estimation results show that real GDP and security web variables are the most important and consistent explanatory variables in a model of military spending in Uganda. Under Museveni, the elasticity of Uganda's defence spending with respect to both GDP and neighbouring military budgets has been higher. At the same time, it seems as if inflows of ODA have acted as a restraint on Ugandan defence spending, possibly indicating the policy conditionality of donors. While statistical limitations of the data prevented a complete analysis of the effects of civil conflict on Ugandan military spending, and of other variables of potential interest, partial results indicate that domestic sources of insecurity do not significantly affect the defence budget.

With respect to the impact on Uganda's defence budget arising from the military spending by individual neighbours, the analysis suggests that Ugandan defence spending moves in the same direction as that of the DRC, Kenya, Sudan, Tanzania, and Egypt. The coefficient on the military spending of Rwanda is unexpectedly insignificant despite the fact that some key informants identified it as a potential threat. While the Rwandan result might reflect the shift in Rwanda from a Ugandan ally to a competitor over the course of the sample period, the positive associations between Uganda's defence spending and those of Kenya and Tanzania are harder to square with the interviews. The finding that the elasticities of Uganda's defence spending to the military budgets of DRC, Sudan and Egypt is more in line with standard security analysis and with the interviews of key informants. So, while there are important elements of consistency between the time series analysis of this chapter and the qualitative analysis of the previous one, there are also some diverging results that future research might shed light on in terms of the details of security relationships and the changes in these relationships over time. 


\section{References}

Baum, C. (2006). An Introduction to Modern Econometrics Using Stata (Texas: Stata Press)

Cameron A., C. and Trivedi K., P. (2010). Microeconometrics Using Stata, Revised Edition (Texas: Stata Press)

Collier, P. and Hoeffler, A. (2002). Military expenditure - threats, aid, and arms races, World Bank WPS2927, online at http://documents.worldbank.org/curated/en/162611468739486410/Military-expenditure-threatsaid-and-arms-races

Dougherty, C. (2011). Introduction to Econometrics, $4^{\text {th }}$ Edition (Oxford: Oxford University Press)

Dunne, P. and Perlo-Freeman, S. (2003). "The Demand for Military Spending in Developing Countries: A Dynamic Panel Analysis," Defence and Peace Economics 14 (6), pp. 461-474.

Dunne, P. and Perlo-Freeman, S. (2003). "The Demand for Military Spending in Developing Countries," International Review of Applied Economics, Vol.17, Issue 1, pp. 23-48

Dunne, P., Perlo-Freeman, S. and Smith R., P. (2008). "The Demand for Military Expenditure in Developing Countries: Hostility versus Capability," Defence and Peace Economics, Volume 19, Issue 4.

Gurajati, D. (2003). Basics Econometrics (New York: McGraw-Hill/Irwin)

Kennedy, P. (2003). A Guide to Econometrics, Fifth Edition (Oxford: Blackwell Publishing)

Hill, C., Griffiths, B. and Lim, G. (2011). Principles of Econometrics, Fourth Edition (Hoboken, NJ: John Wiley \& Sons, Inc.)

Pesaran, M. H., and Y. Shin (1998). “An Autoregressive Distributed-lag Modelling Approach to Cointegration Analysis," In Econometrics and Economic Theory in the 20th Century. The Ragnar Frisch Centennial Symposium (ed. S. Strøm), Chap. 11, 371-413. (Cambridge: Cambridge University Press).

Pesaran, M. H., Y. Shin, and R. Smith (2001). "Bounds testing approaches to the analysis of level relationships,” Journal of Applied Econometrics, 16(3): 289-326.

Rosh, R. M. (1988). "Third World Militarization: Security Webs and the States They Ensnare." Journal of Conflict Resolution 32 (4), pp. 671-698.

Wooldridge, J. (2013). Introductory Econometrics: A Modern Approach $-5^{\text {th }}$ Edition (Mason, $\mathrm{OH}$ : South-Western, Cengage Learnings)

World Bank development indicators database. 


\section{Chapter 3. The Demand for Military Spending in Sub-Saharan Africa: A Panel Analysis}

\subsection{Introduction}

This chapter analyzes the determinants of military expenditures in Sub-Saharan Africa (SSA) using panel data. As discussed in the introduction, military expenditure in SSA has been on the rise since the mid-1990s. Despite the observed increase, there are noticeable variations across countries, sub-regions and time. The increase of defence spending deserves investigation given the region's daunting development challenges on the one hand, and the inability of many governments to provide adequate security to their citizens, on the other hand. The research question the chapter seeks to answer is: why are the levels of military expenditure in SSA increasing? To answer this question, I try to identify the socio-economic, strategic and political variables driving the demand for military expenditures in the SSA region. The analysis in this chapter contributes to our understanding of the demand for military spending in developing countries in one specific way: it is the first comprehensive analysis of the demand for military expenditures in 30 Sub-Sahara African countries (see list in the appendix) for the period of 19882016. It examines the role of economic, demographic, political and institutional factors among the explanatory variables. I organize the remainder of this chapter as follows. Section 1 deals with the model's specification. Section 2 presents the variables. Section 3 presents the results of the empirical estimations and section 4 concludes.

\subsection{Hypotheses and Variables}

The previous chapter focused on the case of Uganda using time series analysis. The main limitation of that approach is that the low number of observations makes it difficult to test more than a few critical variables. By extending the analysis to a panel of Sub-Saharan African 
countries, it is possible to test the same hypotheses as those in the Uganda case as well as the role of other factors. In the previous Uganda study, it was necessary to reduce the number of variables used in any given model due to the limitations of the data set, whereas in the panel we can test several of them at the same time without running into problems of small sample sizes.

The dependent variable in the analysis is the log of the level of military expenditures, measured initially in constant 2010 \$US. I use data on military expenditures for each country from SIPRI database. As noted earlier, and confirmed by the Ugandan field interviews, policy processes are more likely to focus on the level of military spending rather than the military burden (defence spending as a proportion of aggregate income). According to Sandler and Hartley (1995), if the objective of the research is to estimate the demand function of military spending (which is the case of this study), then the level of military spending is the appropriate dependent variable, rather than military burden.

The following sub-section defines the independent variables used in the main analysis, identifies their units of measurement, and discusses the expected signs of their coefficient estimates. In many cases, there is mixed evidence about how the explanatory variables may be related to military spending. A formal hypothesis is identified representing one of the contending arguments about the relationship; though in most cases the tests will be treated as a two-tailed due to the ambiguity of the expectations. Table 13 provides the summary statistics of the key variables.

3.2.1 Population (millions of people). Although the precise effect of population on military expenditure is inconclusive, I include this variable to account for the country's demography. Some studies have found that population has a negative influence on defence spending (see Dunne and Perlo-Freeman 2003 and Wang 2013); while some others have found that it has the 
opposite effect (Hill, 1978; Dudley and Montmarquette, 1981). Past studies have tended to either mix African countries with others or used smaller samples from SSA. Given the ambiguous effect of population found in past studies, I hope to clarify the effect for SSA. For the purposes of investigation, I structure to hypothesis on the basis of Dunne and Perlo-Freeman (2003) and Wang (2013).

Hypothesis 1: If the population of a country is higher, military spending will be lower.

3.2.2 Real GDP (constant 2010 US\$). This variable captures the scale of the national economy and reflects the availability of resources. Research has shown that the availability of economic resources in developing countries positively influences the level of defence budget (Maizels and Nissanke, 1986; McKinlay, 1989). I use data from the World Bank Development Indicators for this variable.

Hypothesis 2: If real GDP is higher, then military spending will also be higher.

3.2.3 The level of military expenditures of neighbours (constant 2010 \$US). This is the sum of the military expenditure of neighbouring states for each period. The inclusion of this variable is important for two reasons. First, defence spending of a country can respond to spending in neighbouring states because of direct military competition (e.g. an arms race) or because of emulation of defence spending (see Collier and Hoeffler, 2002 and Dunne and Perlo-Freeman, 2003). To this traditional list, I would also note the possibility that neighbouring states might face common threats. Second, security threats to a country arise generally from its neighbours (see Rosh, 1988 and Buzan and Waever, 2003). It is therefore expected that military expenditure of neighbouring states will have a positive effect on a country's own defence spending. In 
constructing this variable, I do not use the average of military spending of neighbours as in Dunne and Perlo-Freeman (2003) and Collier and Hoeffler (2002). The reason is simply that, as discussed in chapter two, military planers only look, broadly, at the level of spending of their neighbours. Therefore, averaging this variable may be misleading and is likely to reduce its potential effect. It is important to emphasize that the level of military expenditure of a country's neighbouring states captures its security web in the terms defined by Rosh (1988) and used by Dunne and Perlo-Freeman (2003).

Hypothesis 3: If military spending in neighbouring states is higher, than domestic military spending will also be higher.

3.2.4 Net official development assistance (constant 2010 \$US). This variable comprises disbursements of loans made on concessional terms with a grant element of at least 25 percent. Its inclusion is important because research has shown that some developing countries use money received from foreign aid to finance defence expenditure (Collier and Hoeffler, 2002). At the same time, SSA countries are particularly dependent on ODA and thus vulnerable to pressure from donors to limit military spending. Given the importance of foreign aid in SSA, I therefore include this variable to assess its potential effect on defence spending of countries in the sample. I frame the associated hypothesis on the basis of resource availability.

Hypothesis 4: If a country received more ODA then it will have higher levels of military spending.

3.2.5 Civil war (a binary variable with value 1 if there is a civil war): To examine the effect of internal security problems, I use a dummy variable with a value of 1 if country experienced a civil war in a given year and zero otherwise. I use data on civil war from Polity IV project of the 
Center for Systemic Peace. ${ }^{48}$ The literature on civil war in Africa is abundant (see Blattman and Miguel 2010, Collier and Hoeffler 2007; and Fearon and Laitin 2003); but only few studies have tested its effect on defence budget. For instance, Collier and Hoeffler (2002) and Dunne and Perlo-Freeman (2003) found that it has a positive influence on defence spending. Of course, in a panel study it could also emerge that those countries with lower military spending generally may be unable to deter internal challengers, and thus may be more likely to suffer from civil war. This reversal in causality may diminish or even reverse the correlation between civil war and military spending. The occurrence of civil wars in SSA post-independence makes the inclusion of this variable in the estimations relevant.

Hypothesis 5: If a country is affected by a civil war then its military spending will be higher.

3.2.6 Political regime (ordinal variable from -10 to 10 ). To capture the influence of government structure, I use the Polity 2 index of the Polity IV project, a score that varies on the spectrum of -10 to 10 with lower values associated with autocratic regimes, and higher values associated with democracy. I include this variable because empirical research has shown that autocratic regimes tend to spend more on the military than democratic regimes (Maizels and Nissanke 1986; Looney 1988; Rosh 1988; Hewitt 1992; Dunne and Perlo-Freeman 2003; Goldsmith 2003; Fordham and Walker 2005; Acemoglu, Ticchi, and Vindigni 2010). The presumed reason why autocrats spend more on the military than democrats do is that the former lack popular legitimacy and rely on force to suppress dissents, while the latter are accountable to their public who may prefer social spending to defence expenditure. Moreover, Bueno de Mesquita, Siverson, and Smith (1999) found that autocratic rulers are less risk-averse regarding

${ }^{48}$ See Polity IV Data Series version 2012 at http://www.systemicpeace.org/inscr/inscr.htm 
wars or military confrontations than democratic rulers are, and thus are more willing to invest in military capacity. Given the failures of democratic process and lack of democratic institutions in many SSA countries, the prominence of neo-patrimonial structures and of centralized states (Adebayo, 2012 and Cheeseman, 2015), it is relevant to include the polity 2 variable to account for its potential effect on defence budget. Table 13 below presents the descriptive statistics of the variables in the models.

Hypothesis 6: If a country has a higher polity 2 score then military spending will be higher.

Table 13. Descriptive Statistics (prior to log transformation)

\begin{tabular}{lrrrrr}
\hline Variable & Obs & Mean & Std.Dev. & Min & Max \\
\hline Military expenditure (million) & 857 & 468 & 914 & 1.6 & 6181.7 \\
Population (million) & 870 & 21.2 & 27.5 & 0.529 & 186 \\
Real GDP (billion) & 867 & 30.8 & 71.5 & 0.431 & 46400 \\
Neighbour's military spending (billion) & 865 & 3.17 & 3.15 & 0.00487 & 16.1 \\
Net ODA (million) & 835 & 870 & 913 & 18.0 & 12900 \\
Civil war & 870 & 0.177 & 0.382 & 0 & 1 \\
Polity2 & 863 & -0.057 & 5.651 & -10 & 9
\end{tabular}

\subsection{Model Specification}

I use two different specifications for the panel data analysis in this study: a fixed effects (FE) model and a dynamic panel data (DPD) model. Each model and the resulting empirical estimates are presented in sequence below, starting with the fixed effects model.

\subsubsection{The Fixed Effects Model}

I adopt the panel data analysis instead of the cross-sectional approach because the former addresses the issues of omitted variable bias, endogeneity of independent variables, and time and country-specific effects; problems that are inherent to the latter. I chose the fixed effects model over the random effect because the Hausman test soundly rejected the null hypothesis that the random effect model is consistent. The sample size comprises 30 countries and 29 periods (1988- 
2016), giving thus a sample size ( $\mathrm{N} x \mathrm{~T})$ of 870 observations. The panel data under examination is strongly balanced. The fixed effect model is of the following form:

$$
Y_{\text {it }}=\beta_{1 i}+\beta_{2} X_{2 i t}+\ldots+\beta_{n} X_{n i t}+\varepsilon_{i t}, i=1 \ldots n, t=1 \ldots T
$$

Where: $Y_{i t}$ is the dependent variable (in logarithm); $\beta 1 i$ represents the country-specific effects (i.e. individual heterogeneity); $\beta_{n}$ are slope coefficients, $X_{n i t}$ are independent variables; and $\varepsilon$ is the error term. Hill, Griffiths, and Lam $(2011)^{49}$ observe that in this model the intercepts $\beta_{1 \mathrm{i}}$ are different for different cross-sectional units, but the slope coefficients $\beta_{\mathrm{n}}$ are constant for all individuals (the intercept captures the individual heterogeneity).

Table 13 presents the results of the fixed effects (FE) model estimations. The difference between the two fixed effect models in the table is the inclusion of the Polity 2 and civil war variables in model 2. I use model 1 as the base case for reference. Because the estimates of real GDP, population, military expenditures of neighbours and Net ODA variables are similar in both models, I focus here on the interpretation of the results for the second model.

Except for Net ODA, the coefficients of all other variables are statistically significant at standard levels of type 1 error, suggesting that they are correlated with military spending in SubSaharan Africa, and may indeed have a causal relationship. Specifically, the results show that, holding other factors constant, a one percent increase in real GDP is associated with a 0.3 percent increase in the size of the defence budget. A one percent increase in the size of population is associated on average with a 1.2 percent increase in defence expenditure. This result is consistent with Hill (1978) and Montmarquette (1981) who found that a larger population demand more of security and render defence expenditure more affordable. Nevertheless, the positive relationship between population and defence spending is not consistent with Dunne and Perlo-Freeman

\footnotetext{
${ }^{49}$ See pages $543-544$ for more discussion on the suitability of this model for short panel.
} 
(2003a) and Wang (2013) who found a negative effect of population on military spending. There are two possible explanations for the negative impact of population. First, a large population provides a country some level of intrinsic security. In fact, a country that has a sizable demography can rely more on a larger army than on military technology. This effect might in fact be particularly relevant for SSA, where financial constraints and relatively lower levels of literacy and numeracy may limit opportunities for the extensive use of advanced weapons systems. Second, a larger population may demand more civil consumption rather than security.

Table 13. Empirical Results of Fixed Effect Estimations

\section{FE Model 1: FE Model 2:}

Dependent Variable

Log Real GDP Log Military spending $0.290^{* * *}(3.39)$ Log Military spending

Log Population $0.973^{* * *}(6.10)$ $0.299^{* * *}(3.41)$

Log Net ODA $0.0425(1.41)$ $1.196^{* * *}(6.95)$

Log Neighbour's military spending $0.108^{* * *}(3.50)$ 0.0507 (1.70)

Civil war $0.156^{* *}(3.02)$

Polity 2 score $-0.0158^{* * *}(-3.65)$

Constant $-19.09^{* * *}(-15.34)$ $-22.90^{* * *}(-15.26)$

\begin{tabular}{lrc}
\hline Number of observations & 817 & 814 \\
$\mathrm{R}^{2}$ & 0.432 & 0.448 \\
\hline t statistics in parentheses. ${ }^{*} p<0.05,{ }^{* *} p<0.01,{ }^{* * *} p<0.001$ &
\end{tabular}

While the coefficient estimate for the log of net ODA does not meet traditional levels of statistical significance, in model 2 it does approach these standards. While caution is necessary in ascribing any interpretation to the result, there is weak or suggestive evidence of a positive association between ODA and military spending in recipient states. While it is necessary to 
accept the null hypothesis of no association, further research and refinements of the estimations may uncover conditions under which SSA countries are able to divert resources towards their military when ODA inflows increase.

One of the key hypotheses is the effect of external security developments for a state's defence spending. The coefficient of the military expenditures of neighbours variable is highly significant and positive. It suggests that, on average and holding all other factors constant, a one percent increase in the total military expenditure of a country's neighbours is associated with an increase of 0.1 percent of its own defence budget. This finding is consistent with Dunne, PerloFreeman, and Smith (2008). One can interpret this positive relationship as an indication of a country's tendency to emulate the defence spending patterns of its neighbours, or a specific reaction to a potential threat posed by one or more of the countries it borders as suggested by Dunne, Perlo-Freeman, and Smith (2008). They define potential enemies as "those countries with whom a country shares a degree of hostility" (p.294). However, without a further analysis of the demand for defence expenditures at dyadic level for countries that may perceive each other either as rival or potential enemies, it is difficult to conclude definitively that the observed positive impact of the military expenditures of neighbours signifies an arms race as defined by Richardson (1960). Richardson defined arms race as an interactive arms-reaction patterns of arms acquisitions or increases in defence expenditures between two countries that have some degree of hostility (the cases of the USA-USSR, India and Pakistan, Greece and Turkey, Israel and its Arab neighbours, are the most notable examples). Given the absence of inter-state conflicts between many states in my sample of SSA states, it is problematic to conclude that this coefficient estimate is evidence of arms race type behaviour. The rarity of traditional inter-state armed conflict in Sub-Saharan Africa suggests that other explanations should be examined 
carefully. One possibility is that groups of countries may react separately but in the same manner to non-state threats emerging in their region, such as terrorist groups or rebel groups. The discussion above does not deny the existence of arms race in SSA, but as Dunne, Perlo-Freeman, and Smith discuss in their paper, the problem is all about empirically deriving an arms-reaction framework between hostile countries in SSA. It would be interesting for further research to determine the level of adversity or hostility between countries covered in this study.

Turning to internal security threats, model 2 yields a positive and statistically significant coefficient estimate for the civil war dummy variable. The presence of a civil war is associated with a 0.156 unit increase in the log of defence spending in the affected state, implying a $15.6 \%$ increase in defence spending. This effect is expected, though further research might helpfully link the severity of the civil war to changes in defence spending.

Finally, the coefficient of Polity 2 is also highly significant and negative. It suggests that as a country moves toward a democracy, it spends less on the military, compared to an autocratic regime. The size of the effect is small, however: an increase of one unit along the scale from -10 to 10 is associated with a about a $0.6 \%$ decrease in defence spending in the average state. Qualitatively, this finding is consistent with previous studies that found that democratic regimes tend to spend less on the military than autocratic regime do. The presence of institutional checks and balances, the legitimacy of the rulers, and the demand for socio-spending in democratic regimes as opposed to autocratic regimes inhibit rulers' ability to spend more on the military (see Lebovic, 2001; Fordham and Walker, 2005; Yildirim Sezgin, 2005, and Wang 2005).

\subsubsection{The Dynamic Panel Data Model}

One concern with the fixed effects model is that it does not take into account potential problems arising from the time-series dimension of the data. Specifically, the fixed effect 
estimator does not adjust for potential non-stationarity, even though it does use a form of differencing. It is possible that the fixed effect model results are, therefore, spurious.

In order to examine this issue, I used a Fisher test for stationarity in panel data. The results appear in Table 14 below. The results indicate that most variables are non-stationary at level, though the first difference is stationary. Only the log of net ODA is stationary at level. Therefore, I also use a dynamic panel data estimation technique.

Table 14. Results of the Fisher Test of Stationarity for the Panel Data

\begin{tabular}{|l|l|l|l|l|l|}
\hline \multirow{2}{*}{ Variables } & & \multicolumn{2}{l}{ Level } & \multicolumn{2}{l|}{ First difference } \\
\cline { 3 - 6 } & & Statistic & p-value & T-Statistic & p-value \\
\hline \multirow{4}{*}{$\begin{array}{l}\text { Log Military } \\
\text { spending }\end{array}$} & Inverse Chi-Sq (60) P & 75.9 & 1.00 & 362 & 0.00 \\
\cline { 2 - 6 } & Inverse normal Z & 1.11 & 1.00 & -14.8 & 0.00 \\
\cline { 2 - 6 } & Inverse Logit t (154) L* & 0.866 & 1.00 & -18.2 & 0.00 \\
\cline { 2 - 6 } & Modified inv.Chi-sq Pm & 1.45 & 1.00 & 27.6 & 0.00 \\
\hline \multirow{4}{*}{ Log Real GDP } & Inverse Chi-Sq (60) P & 8.56 & 1.00 & 280 & 0.00 \\
\cline { 2 - 6 } & Inverse normal Z & 9.69 & 1.00 & -10.3 & 0.00 \\
\cline { 2 - 6 } & Inverse Logit t (154) L* & 10.6 & 1.00 & -13.6 & 0.00 \\
\cline { 2 - 6 } & Modified inv.Chi-sq Pm & -4.70 & 1.00 & 20.1 & 0.00 \\
\hline \multirow{4}{*}{ Log Net ODA } & Inverse Chi-Sq (60) P & 91.8 & 0.0051 & 494 & 0.00 \\
\cline { 2 - 6 } & Inverse normal Z & -1.66 & 0.0487 & -17.7 & 0.00 \\
\cline { 2 - 6 } & Inverse Logit t (154) L* & -2.14 & 0.0171 & -24.9 & 0.00 \\
\cline { 2 - 6 } & Modified inv.Chi-sq Pm & 2.91 & 0.0018 & 39.7 & 0.00 \\
\hline Log Population & Inverse Chi-Sq (60) P & 52.8 & 0.735 & 762 & 0.00 \\
\cline { 2 - 6 } & Inverse normal Z & 7.14 & 1.00 & -21.6 & 0.00 \\
\cline { 2 - 6 } & Inverse Logit t (154) L* & 7.37 & 1.00 & -38.2 & 0.00 \\
\cline { 2 - 6 } & Modified inv.Chi-sq Pm & -0.660 & 0.745 & 64.1 & 0.00 \\
\hline \multirow{4}{*}{$\begin{array}{l}\text { Log Military } \\
\text { spending of all } \\
\text { neighbours }\end{array}$} & Inverse Chi-Sq (60) P & 74.0 & 0.105 & 385 & 0.00 \\
\cline { 2 - 6 } & Inverse normal Z & 0.574 & 0.717 & -15.2 & 0.00 \\
\cline { 2 - 6 } & Inverse Logit t (154) L* & 0.341 & 0.633 & -19.3 & 0.00 \\
\cline { 2 - 6 } & Modified inv.Chi-sq Pm & 1.28 & 0.100 & 29.7 & 0.00 \\
\hline
\end{tabular}

This second specification is a dynamic panel data model using the Arellano-Bover and Blundell-Bond (Arellano and Bond, 1991; see also Arellano and Bover, 1995 and Blundell and Bond 1998) system GMM approach. I adopt this approach because it addresses the problem of endogeneity of regressors, avoids the problem of dynamic panel bias and accommodates multiple endogenous regressors (Roodman, 2009). Moreover, as Roodman discusses, the System GMM is 
useful because it uses its own internal instrument variables and is suitable for small time period and large panel. The Arellano-Bond specification I use is consistent with the approach adopted by Dunne and Perlo-Freeman (2003a \&b) and Wang (2013). It is of the following form:

$$
\mathrm{Y}_{\text {it }}=\lambda \mathrm{Y}_{\mathrm{it}-1}+\beta^{\prime} \mathrm{X}_{\mathrm{it}}+\alpha^{*}{ }_{\mathrm{it}}+\varepsilon_{\mathrm{it}, \mathrm{i}} \mathrm{i}=1 \ldots \mathrm{n}, \mathrm{t}=1 \ldots \mathrm{T}
$$

Where: $Y_{i t}$ is the level of military expenditure of country $\mathrm{i}$ at time $\mathrm{t} ; \beta^{\prime}$ represents the slope coefficients; $X_{i t}$ represents the explanatory variables other than the lagged of military expenditure; $\alpha_{i t}^{*}$ represents any country-specific effect, and $\varepsilon_{i t}$ is the disturbance term.

Table 15 below presents the results of the dynamic panel data estimations. As in the fixed effect models, the difference between the two models in the table is that, compared to model 1 , model 2 includes the Polity 2 and civil war binary variables. The reports of the test for serial correlation in the first-differenced residuals and the test of over-identifying restrictions (Sargan test) are satisfactory. The results in model 2 indicate that lagged military expenditures, real GDP, military expenditures of neighbours and population are all important determinants of the demand for defence spending. In contrast to the fixed effect models, the coefficient of the civil war variable is statistically insignificant in this dynamic panel data model, while that of the Polity 2 variable is at best only marginally significant statistically. The Arellano-Bond model uses a partial adjustment to account for the dynamic nature of the panel analysis, the coefficient of lagged military expenditure reflects the speed of adjustment of 0.37 (1-0.634). This speed of adjustment suggests that 37 percent of the impact from a sudden change in the determinants of military spending is reflected in the immediate period. 
Table 15. Empirical Results of the Dynamic Panel Data Estimations

\begin{tabular}{lcc}
\hline Dependent Variable & $\begin{array}{c}\text { DPD Model 1 } \\
\text { Log Military spending }\end{array}$ & $\begin{array}{c}\text { DPD Model 2 } \\
\text { Log Military spending }\end{array}$ \\
\hline Lag Log Military spending & $0.630^{* * *}(23.48)$ & $0.634^{* * *}(16.97)$ \\
Log Population & $0.165(1.32)$ & $0.399^{* *}(3.01)$ \\
Log Real GDP & $0.169^{*}(2.29)$ & $0.134^{*}(1.90)$ \\
Log Net ODA & $-0.0271(-1.82)$ & $-0.0155(-0.99)$ \\
Log Neighbour's military spending & $0.209^{* * *}(12.11)$ & $0.187^{* * *}(9.78)$ \\
Civil War & & $0.192(1.45)$ \\
Polity 2 score & & $-0.00499(-1.86)$ \\
Constant & $-5.656^{* * *}(-10.10)$ & $-8.771^{* * *}(-5.09)$ \\
\hline N & 759 & 756 \\
AR(1) & & \\
AR(2) & $-2.1913, \mathrm{P}=0.0284$ & $-2.1836, \mathrm{P}=0.0290$ \\
Sargan Chi-Square $(25)$ & $0.77819, \mathrm{P}=0.4365$ & $0.85898, \mathrm{P}=0.3904$ \\
& $24.46 .397, \mathrm{P}=0.4927$ & $19.73218, \mathrm{P}=0.7607$ \\
\hline
\end{tabular}

$t$ statistics in parentheses, ${ }^{*} p<0.05,{ }^{* *} p<0.01,{ }^{* * *} p<0.001$

$\mathrm{AR}$ (1) and AR (2) tests indicate no serial correlation in the first-differenced errors at a higher order than one.

To examine the association between defence spending and the key explanatory variables associated with the hypotheses, I focus on the coefficient estimates from Model 2 in table 15. The first key variable is population. The statistically significant coefficient estimate of 0.399 indicates that a $1 \%$ increase in population is associated with a $0.4 \%$ increase in defence spending. Similarly, a $1 \%$ increase in real GDP is associated with a $0.13 \%$ increase in defence spending. These values both seem a little high, though they are plausible, and it should be recalled that these are average effects across the SSA sample and may reflect the marginal effects of growth on defence spending in some key states. As was the case with the fixed effects model, no reasonable claim can be made regarding the correlation of net ODA and military spending. 
The external security environment does appear to have a strong effect on defence spending. An increase in military expenditures by neighbouring states (collectively) of $1 \%$ is associated with a $0.19 \%$ increase in military spending for a SSA country. This coefficient estimate is plausible in terms of its magnitude, and since it is significantly smaller than 1 , it also is consistent with a reasonably stable security environment, since an exogenous increase in one country's defence budget is unlikely to initiate an explosive cycle of military spending in its neighbourhood. Unlike the fixed effects model, the dynamic panel estimation does not yield a statistically significant coefficient estimate for the indicator of internal security threats; there appears to be no strong and consistent association between civil wars and defence spending. Although the coefficient estimate is positive as expected and has a plausible and reasonably large magnitude, the standard error of the estimate is very high. This unexpected effect may reflect problems with using an indicator variable that fails to capture the relative severity of civil conflicts. Further investigation of this relationship may be very useful for understanding military spending in SSA. Finally, there is weak evidence that higher democracy scores according to the polity 2 measure are associated with lower defence spending, though the effect is small: a one unit increase in the Polity 2 score reduces defence spending by only $0.5 \%$.

\subsection{Post Estimation and Robustness Tests}

I first test for the possibility of the existence of a linear relationship between all the regressors (multicollinearity) by using the Variance-Inflation Factor test. The result of this test

shows an overall VIF value of 3.1 with no single VIF score over 6 . Based on this result, I conclude that multicollinearity is not a serious problem for the analysis. The RAMSET test rejects the null hypothesis of omitted variables. These tests, including the Arellano Bond tests 
$\mathrm{AR}$ (1) and AR (2) indicate that the models do not suffer from these basic problems of misspecification.

A more problematic issue arises from the possibility of heteroscedasticity. It is not possible to use a standard test of heteroscedasticity in the estimations themselves but running the estimations as OLS models and using the Breusch-Pagan tests suggest that heteroscedasticity may be a problem. A review of the residuals from the actual models does not indicate a serious problem. As a precaution, I run the Arellano-Bond model with robust standard errors, and the two-step Arellano-Bond model, which should also be consistent and asymptotically efficient in the presence of heteroscedasticity. In both cases, these supplementary estimations supported the basic findings with respect to the adjustment term from the lagged dependent variable, as well as the strong positive associations of military spending with population and the military spending of neighbours. In versions of the model where population was not used, real GDP also has a positive relationship with military spending, suggesting that to some extent population and real GDP are both measuring a dimension of scale of a country that is connected with the defence budget. In these models, the null hypotheses that the coefficient estimates for net ODA, civil war, and Polity 2 are zero could not be rejected, so some of the results in the previous subsection need to be viewed with caution.

\subsection{Conclusion}

The objective of this chapter was to examine the determinants of military spending in 30 countries of Sub-Saharan Africa. Two distinct specifications are performed, the fixed effect and the dynamic panel data models. From the results of different regressions performed in this chapter, I conclude that the most important explanatory variables of the determinants of military spending are the size of the economy and population and changes in the level of military 
spending of neighbouring countries, and the lagged value of military spending which reflects inertia. Furthermore, the estimations of the fixed effect models show that the nature of the political regime (autocracy and democracy) and the occurrence of civil war also influence the defence budget. However, the estimations of the dynamic panel models fail to corroborate this influence as found in the fixed effect model. While this analysis does provide useful insight into the defence spending in Sub Saharan Africa, further research is required to test additional variables and models in order to obtain a more complete picture of military budgets in the region. 


\section{References}

Acemoglu, D., D. Ticchi, and A. Vindigni. (2010). "A Theory of Military Dictatorships," American Economic Journal: Macroeconomics 2 (1), pp. 1-42.

Adebayo, A. (2012). Managing Conflicts in Africa's Democratic Transitions (Lanham, Md: Lexington Books)

Blattman, C. and Miguel, E. (2010). “Civil War.” Journal of Economic Literature 48 (1), pp. 357.

Bueno de Mesquita, B., S. Morrow, R. M. Siverson, and A. Smith. (1999). "An Institutional Explanation of the Democratic Peace," The American Political Science Review 93 (4), pp.791807.

Cheeseman, N. (2015). Democracy in Africa: Successes, Failures, and the Struggle for Political Reform (Cambridge: Cambridge University Press).

Collier, P. and Hoeffler, A. (2002). Military Expenditure: Threats, Aid, and Arms Races. World Bank Policy Research Working Paper No. 2927

Dunne, J. P., and S. Perlo-Freeman. (2003). "The Demand for Military Spending in Developing Countries: A Dynamic Panel Analysis," Defence and Peace Economics 14 (6), pp. 461-474.

Dunne, J. P., and R. P. Smith. 2010. "Military Expenditure and Granger Causality: A Critical Review." Defence and Peace Economics 21 (5-6), pp.427-441.

Fearon, D. and Laitin, D. (2003). "Ethnicity, Insurgency, and Civil War." American Political Science Review 97 (1), pp. 75-90.

Fordham, B. and Walker, T. (2005). "Kantian Liberalism, Regime Type and Military Resource Allocation," International Studies Quarterly, 49(1), pp. 141-157.

Horowitz, Donald L. (1985). Ethnic Groups in Conflict. (Berkeley: University of California Press).

Lebovic, J. (2001). "Spending priorities and democratic rule in Latin America," Journal of Peace Research, 45(4), pp. 427-452.

Leon, G. (2014). "Loyalty for sale? Military Spending and Coups d'état," Public Choice 8, pp. $1-21$.

Looney, R. (1988). "The Political Economy of Third World Military Expenditures: The Impact of Regime Type on Defence Allocation Process," Journal of Political and Military Sociology, Vol 16(1), pp. 21-29. 
Maizels, A. and Nissanke, M. (1986). "The Determinants of Military Expenditure in Developing Countries", World Development, Vol.14 (9): pp. 1125-1140.

Majeski, S. (1983). "Mathematical Models of US Military Expenditure Decision-making Process," American Journal of Political Science 27(3), pp. 485-514.

McGowan, P. J.(2003). “African Military Coups d'état, 1956-2001: Frequency, Trends and Distribution," Journal of Modern African Studies 41 (3), pp. 339-70.

McKinlay, R. (1989). Third World Military Expenditure: Determinants and Implications. (London: Printer).

Rattinger, H. (1975). "Armaments, Detente, and Bureaucracy," Journal of Conflict Resolution, 19(4), pp. 571-595.

Roessler, P. (2011). "The Enemy Within: Personal Rule, Coups, and Civil War in Africa," World Politics 63 (2), pp. 300-346.

Roodman, D. (2009). "A Note on the Theme of Too Many Instruments." Oxford Bulletin of Economics and Statistics, Vol. 71 (1): 135-158.

Roodman, D. (2009). "How to do xtabond2: An introduction to difference and system GMM in Stata," The Stata Journal, Vol.9 (1): 86-136

Rosh, R. M. (1988). "Third World Militarization: Security Webs and the States They Ensnare." Journal of Conflict Resolution 32 (4), pp. 671-698.

SIPRI Military Expenditure database, available online at https://www.sipri.org/databases/milex

Smith, R. (2009). Military Economics: The Interaction of Power and Money (New York: Palgrave Macmillan).

Sandler, T. and Hartley, K. (1995). The Economics of Defense. (Cambridge: Cambridge University Press).

Yildirim, J. and Sezgin, S. (2005). "Democracy and Military Expenditure," Transition Studies Review 12(1), pp. 93-100.

Yu Wang (2013). "Determinants of Southeast Asian military spending in the post-cold war era: a dynamic panel analysis," Defence and Peace Economics, Vol. 24 (1), pp. 73-87. 


\section{General Conclusion}

The purpose of this dissertation was to examine the demand for military spending in SubSaharan Africa. In fact, statistics show that military expenditures in Sub-Saharan Africa exhibit important variations: a general trend of growth over time, significant differences between countries and between sub-regions, and distinct patterns of spending over time between and within countries. Hence, understanding why there is such variation in military expenditures in Sub-Saharan Africa, across time, across countries and sub-regions, is an important research question. In examining this question, I sought to empirically identify the key national, subregional and regional determinants of military spending in Sub-Saharan Africa and provide persuasive explanations of the trend in military spending over time and across countries.

From a public policy perspective, understanding why the levels of military expenditures in Sub-Saharan Africa are on the rise is crucial in many ways. On the one hand, military expenditures are crucial for states because they represent investment in the production of order and security, two public goods that are conducive to development when provided at sufficient levels. From the perspective of international relations, realists argue that a state's military capability is its main instrument for achieving national security and asserting and protecting sovereignty. Therefore, military spending is crucial in ensuring the state's capability to defend its territory and citizens from foreign aggression. Sub-Saharan Africa provides an interesting case for applying this theory, since traditional inter-state conflict is rare, and so our conception of this traditional approach needs to be broadened to incorporate the military's role in the context of external threats from foreign actors, external threats arising from internationalized internal conflicts, and internal threats in the form of civil wars and insurgencies. 
On the other hand, military expenditures are generally seen as a resource diversion away from other forms of more productive investment and beneficial consumption, and thus they have a negative impact on development. This resource-diversion argument maintains that the more countries spend on the military, the more they reduce the amount of resources available for productive sectors of the economy that have the potential for fostering sustainable growth and poverty reduction. The policy dilemma is that developing countries need to strike the balance in the allocation of scarce resources between the military and sectors that foster development. Based on the above arguments and given the presence of widespread poverty in Sub-Saharan Africa, it is thus important to understand the drivers of military spending in the sub-continent.

In addition to the introduction, this dissertation comprises three chapters. In the first chapter, I use a qualitative methodology to discuss three important issues related to Uganda's defence budget. I selected Uganda as the case study for three main reasons. First, it has a long history of civil wars and military coups, and the military elite has often exerted substantial control or influence over the political system. Second, Uganda has a strong military presence in regional conflicts, whether in the central Africa region or in the Horn of Africa. Its interventionist foreign policy in such conflicts as those in the Democratic Republic of Congo, Somalia and South Sudan has put pressure on its military budget. Last, Uganda has been one of the major beneficiaries of foreign aid in Sub-Saharan Africa. Research has shown that, due to the fungibility of foreign aid, development aid leaks into military spending. I gathered the information that forms the basis of this chapter one through structured interviews I conducted during the fieldwork in Kampala (Uganda's capital city) from July 21 to August 22, 2016. The purpose of the fieldwork was to get firsthand information on both the process of and the security 
threats that influence the defence budget in Uganda from experts and technocrats who have deep knowledge of Uganda's security environment.

Chapter one first analyses the process leading to the formulation of the military budget, the actors who have the final decision in that process, and the structure of the defence budget. The analysis from the fieldwork shows that in principle Uganda's military budget is embedded in the process of the national budget, thereby demonstrating that Uganda's military is treated as a normal and integral part of the government and society. However, the analysis also shows that the President of the Republic, to a larger degree through his ruling party, exercises significant power over the military budget including having the final decision on its level. The analysis also shows that there is a lack of transparency in the defence budget caused by classified expenditures. The exact amount of these expenditures as well as their use are not revealed to the public, except to the Auditor General of the Republic. The power the President has over the defence budget and the classified expenditures impede the ability of the Parliament to discharge effectively its mandate to provide budget oversight and checks and balances within the system. The implications of this problem are twofold: an increased likelihood of corruption and rent seeking within the military, and the weakening of political and economic institutions that are in charge of not just defence and security, but also other critical social and political projects such as national development.

Second, the data show that the defence budget, while increasing in level, has grown somewhat more slowly than other key components of the national budget, such as expenditures on education, public infrastructure, and health. The evolution of the defence budget, therefore, suggests that it has not dominated other areas of spending that are more immediately associated with social and economic development. 
Third, the analysis identifies the different external and internal threats Uganda faces, which in turn could be expected to the level of defence spending and the process by which it is approved. The external security threats Uganda faces are twofold. First, political instability in both the DRC and South Sudan, and, second, transnational terrorism from Al-Shabaab in Somalia. Political instability in the DRC and South Sudan is generally perceived as the primary source of Uganda's external security threat for several reasons. Instability in its neighbours has resulted in refugees' inflows into Uganda, the presence of armed groups hostile to the Ugandan regime, such as the Allied Democratic Forces and the LRA in ungoverned spaces in eastern DRC, and the circulation of small and light weapons that may end up in the hands of organized criminal groups that can threaten the regime. From an interstate conflict perspective, however, the research shows that none of the states neighbouring Uganda is perceived as an immediate threat because the risk of a military confrontation is minimal. Internally, the most pressing security threats Uganda faces are threefold, namely youth unemployment, potential ethnic conflict, and the longevity of the President's tenure in office and the ensuing uncertainty over power transition should he die. Most research participants cited these three problems as threats to Uganda's security and development, though their effect on the level of the defence budget is unlikely to be dramatic, since the UPDF does not have primary responsibility for internal security. Instead, it is secondary linkages through problems such as favoritism and corruption in the military that may connect internal security concerns with defence spending.

Overall, the analysis in chapter one shows that defence spending in Uganda generally follows a process of intra-governmental bargaining and political oversight over public expenditures. Despite the government's military roots, and the President's ultimate control over military spending, the defence budget has not overwhelmed other government priorities. In 
addition, the nature and level of internal and external threats to Uganda do not seem to be posing a serious challenge to its security. While there are several perceived threats that may influence Uganda's defence budget, the limited volatility of military spending over time suggests that overall there is a perception that Uganda's government has been able to provide a reasonable level of security without compromising its obligations to promote social and economic development as well.

In chapter two, I examine the most important factors that influence the demand for military spending in Uganda, with a focus on President Museveni's reign. Methodologically, I use the auto-regressive distributed lag model (ARDL) for the quantitative analysis in this second chapter. The ARDL model is suitable for this analysis because of the dynamic relationships between the variables. Because the data in the estimated model are a time-series, I performed the tests of stationarity of the variables. The reason is that regressions of non-stationary time-series can yield spurious estimates. The results of the test of stationarity showed that the variables of interests are all integrated of order one. Because the series are stationary in their first differences, I performed the Johansen Test of co-integration to account for the dynamic relationship between the variables. I reject the null hypothesis of no co-integration based on the Trace and maximum Eigen Value statistics from the Johansen test. Moreover, the coefficient of the error correction parameter confirmed the presence of a long run causality from the independent variables to the dependent variable.

The estimation results show that real GDP and security web variables are the most important and consistent explanatory variables in a model of military spending in Uganda. Under President Museveni, the elasticity of Uganda's defence spending with respect to both GDP and neighbouring military budgets has been higher. At the same time, it seems as if inflows of ODA 
have acted as a restraint on Ugandan defence spending, possibly indicating the policy conditionality of donors. While statistical limitations of the data prevented a complete analysis of the effects of civil conflict on Ugandan military spending, and of other variables of potential interest, partial results indicate that domestic sources of insecurity do not significantly affect the defence budget.

With respect to the impact on Uganda's defence budget arising from the military spending by individual neighbours, the analysis suggests that Ugandan defence spending moves in the same direction as that of the DRC, Kenya, Sudan, Tanzania, and Egypt. The coefficient on the military spending of Rwanda is unexpectedly insignificant despite the fact that some key informants identified it as a potential threat. While the Rwandan result might reflect the shift in Rwanda from a Ugandan ally to a competitor over the course of the sample period, the positive associations between Uganda's defence spending and those of Kenya and Tanzania are harder to square with the interviews. The finding that the elasticities of Uganda's defence spending to the military budgets of DRC, Sudan and Egypt is more in line with standard security analysis and with the interviews of key informants. Therefore, while there are important elements of consistency between the time series analysis of this chapter and the qualitative analysis of the previous one, there are also some diverging results that future research might shed light on in terms of the details of security relationships and the changes in these relationships over time

Finally, in chapter three, I examine the determinants of military spending in a large sample of 30 countries of Sub-Saharan Africa for the period of 1988-2016. Methodologically, I perform the estimations of the fixed effect and the dynamic panel data models. From the results of different regressions performed in this chapter, I conclude that the most important explanatory variables of the determinants of military spending are the size of the economy, demography, 
changes in the level of military spending of neighbouring countries, and the lagged of military spending which reflects inertia. Furthermore, the estimations of the fixed effect models show that the nature of the political regime (autocracy and democracy) and the occurrence of civil war also influence the defence budget. However, the estimations of the dynamic panel models fail to corroborate this influence as found in the fixed effect model. Finally, the results of post estimation tests of both fixed effect and dynamic panel data models show that these models are suitable and efficient for this analysis. 


\section{Appendix. List of Countries and Neighbours (Security Web)}

\begin{tabular}{|c|c|c|}
\hline ID & Country & Neighbours (Security Web) \\
\hline 1 & Angola & $\begin{array}{l}\text { Congo Brazzaville, the Democratic Republic of Congo } \\
\text { (DRC), Namibia, South Africa, and Zambia. }\end{array}$ \\
\hline 2 & Botswana & Namibia, South Africa, Zambia, and Zimbabwe \\
\hline 3 & Burkina Faso & Benin, Cote d'Ivoire, Ghana, Togo, Niger, Mali \\
\hline 4 & Burundi & DRC, Rwanda, and Tanzania \\
\hline 5 & Cameroon & $\begin{array}{l}\text { Central Africa Republic, Chad, Congo Brazzaville, } \\
\text { Equatorial Guinea, and Nigeria }\end{array}$ \\
\hline 6 & Chad & $\begin{array}{l}\text { Central Africa Republic, Cameroon, Libya, Niger, } \\
\text { Nigeria, and Sudan }\end{array}$ \\
\hline 7 & $\begin{array}{l}\text { The Democratic Republic of Congo } \\
\text { (DRC) }\end{array}$ & $\begin{array}{l}\text { Angola, Burundi, Central African Republic, Congo } \\
\text { Brazzaville, Rwanda, South Sudan, Sudan, Tanzania, } \\
\text { Uganda, and Zambia }\end{array}$ \\
\hline 8 & Côte d'Ivoire & Burkina Faso, Ghana, Guinea, Liberia, Mali \\
\hline 9 & Djibouti & Ethiopia, Eritrea, and Somalia \\
\hline 10 & Ethiopia & $\begin{array}{l}\text { Djibouti, Eritrea, Kenya, South Sudan, Sudan, and } \\
\text { Somalia }\end{array}$ \\
\hline 11 & Gambia & Senegal \\
\hline 12 & Ghana & Burkina Faso, Ivory Cost, and Togo \\
\hline 13 & Kenya & $\begin{array}{l}\text { Ethiopia, Somalia, South Sudan, Sudan, Tanzania, and } \\
\text { Uganda }\end{array}$ \\
\hline 14 & Lesotho & South Africa \\
\hline 15 & Malawi & Mozambique, Tanzania, Zambia \\
\hline 16 & Mali & $\begin{array}{l}\text { Algeria, Burkina Faso, Guinea, Ivory Cost, Mauritania, } \\
\text { Niger, and Senegal }\end{array}$ \\
\hline 17 & Mauritania & Algeria, Mali, Morocco, and Senegal \\
\hline 18 & Mozambique & Malawi, Tanzania, South Africa, Zambia, and Zimbabwe \\
\hline 19 & Namibia & Angola, Botswana, South Africa, Zambia \\
\hline 20 & Nigeria & Benin, Cameroon, Chad, Niger \\
\hline 21 & Rwanda & Burundi, DRC, Tanzania, and Uganda \\
\hline 22 & Senegal & Gambia, Mali, Mauritania, Guinea, and Guinea Bissau \\
\hline 23 & Sierra Leone & Guinea and Liberia \\
\hline 24 & South Africa & $\begin{array}{l}\text { Botswana, Lesotho, Mozambique, Namibia, Swaziland, } \\
\text { and Zimbabwe }\end{array}$ \\
\hline 25 & Sudan & $\begin{array}{l}\text { CAR, Chad, DRC, Egypt, Eritrea, Ethiopia, and South } \\
\text { Sudan }\end{array}$ \\
\hline 26 & Swaziland & Mozambique and South Africa \\
\hline 27 & Tanzania & $\begin{array}{l}\text { Burundi, DRC, Malawi, Mozambique, Kenya, Rwanda, } \\
\text { Uganda, and Zambia }\end{array}$ \\
\hline 28 & Uganda & $\begin{array}{l}\text { DRC, Egypt, Kenya, Rwanda, South Sudan, Sudan, and } \\
\text { Tanzania }\end{array}$ \\
\hline 29 & Zambia & $\begin{array}{l}\text { Angola, Botswana, DRC, Malawi, Mozambique, Namibia, } \\
\text { Tanzania, South Africa, Zimbabwe }\end{array}$ \\
\hline 30 & Zimbabwe & $\begin{array}{l}\text { Botswana, Mozambique, Namibia, South Africa, and } \\
\text { Zambia }\end{array}$ \\
\hline
\end{tabular}

